\title{
Tópicos elementares de Teoria de Códigos como motivação para o ensino da divisibilidade
}

\author{
Liliane Soares de Siqueira Feola
}

Dissertação apresentada ao Instituto de Matemática e

Estatística da Universidade de São Paulo para obtenção do título de Mestre em Ciências

Programa: Mestrado Profissional em Ensino de Matemática

Orientador: Prof. Dr. Francisco César Polcino Milies 


\section{Tópicos elementares de Teoria de Códigos como motivação para o ensino da divisibilidade}

Esta versão contém as correções e alterações sugeridas pela Comissão Julgadora durante a defesa da versão original do trabalho, realizada em 02/05/2016. Uma cópia da versão original está disponível no Instituto de Matemática e Estatística da Universidade de São Paulo.

Comissão Julgadora:

- Prof. Dr. Francisco Cesar Polcino Milies (Orientador) - IME - USP

- Prof. Dr. Raul Antonio Ferraz - IME - USP

- Prof. Dr. Ruy Cesar Pietropaulo - UNIAN 

A minha família e amigos que fizeram parte da realização desse sonho.

Ao meu querido pai que, certamente, estaria vibrando comigo, por mais esta conquista.

(in memoriam)

Aos meus alunos, minhas fontes de inspiração. 



\section{AGRADECIMENTOS}

A Deus, por ter me dado o presente de realizar um grande sonho, pelo auxilio e proteção.

Ao meu orientador, Prof. Dr Francisco César Polcino Milies, por compartilharmos, desde o início da orientação, do mesmo anseio como educadores, na busca de desenvolver um tema que fosse significativo aos alunos. Foi um privilégio tê-lo como meu orientador e, sobretudo, um amigo, pois, ao longo de toda a trajetória, ele sempre apresentou uma postura dedicada, solicita e interessada.

Aos professores Dr. Raul Antônio Ferraz e Dr. Ricardo Bianconi pela colaboração e por terem aceitado participar da banca de defesa.

Ao Instituto de Matemática e Estatísticas da USP por oferecer o curso de Mestrado Profissional em Ensino de Matemática do qual fiz parte e tive a grande oportunidade de aprender com meus professores, especialmente as Professoras Dra. lole de Freitas Druck e Dra. Cristina Cerri.

A Profa. Dra. Claudia Cueva Candido por ter me incentivado e orientado a recomeçar uma trajetória que possibilitou alcançar as condições para ingresso nesse Mestrado.

A Profa. Dra. Ana Paula Jahn pelas ótimas sugestões. Além das suas orientações sobre Metodologias, que tanto contribuíram para o meu aprendizado.

A Profa. Dra. Maria Izabel Ramalho Martins por todo o apoio, carinho e incentivo.

Ao meu querido marido, Julio, pelo amor e incentivo inabaláveis, por dividir comigo todos os desafios e conquistas da minha vida.

Aos meus amados filhos, Aline e Vitor, pelo cuidado e carinho constantes, por compartilharem do meu sonho sempre ao meu lado.

A minha mãe, pela segurança transmitida através das suas palavras e pelo seu amor.

A minha amiga Maria José, pelo afeto, zelo e encorajamento, por ter me acompanhado em todas as etapas da realização deste trabalho.

A minha amiga Marília, pelo companheirismo e pela dedicação de horas de estudo ao meu lado. 

Aos colegas da Graduação e do Mestrado, pela convivência, pelos momentos de alegria e de trabalho, especialmente: Cynthia, Douglas, Caio, Ana Luiza e Paolo.

A minha querida Juliana pela colaboração, carinho e disponibilidade.

As queridas amigas Iracema, Regina, Maria Aparecida e Maria Ângela pelas orações e incentivo.

A direção do Instituto Nossa Senhora Auxiliadora pela confiança em permitir a aplicação das atividades aos alunos. 




\section{RESUMO}

FEOLA, L. S. S. Tópicos Elementares de Teoria de Códigos como motivação para o ensino da divisibilidade. 2016. 117 f. Dissertação (Mestrado) - Instituto de Matemática e Estatística, Universidade de São Paulo, São Paulo, 2016.

Este trabalho tem como objetivo oferecer ao professor de matemática subsídios que permitam desenvolver atividades pedagógicas relacionadas aos conceitos básicos de divisibilidade de números inteiros. Para tanto, optou-se por desenvolvê-las de modo a possibilitar ao aluno a compreensão das ideias matemáticas envolvidas na detecção de erros de digitação em códigos numéricos utilizados nos códigos de barras e também no RG, CPF e ISBN. Vale ressaltar que tais atividades foram inspiradas nas metodologias de Resolução de Problemas e Atividades Investigativas - embora, em alguns momentos, fizeram-se necessárias determinadas adaptações de acordo com o conteúdo. Assim, munidos desses elementos, os professores poderão dar aos alunos a oportunidade de desenvolver habilidades e competências da teoria elementar de números, aprimorar seus conhecimentos relacionados a situações do cotidiano e explicitar relações entre matemática e tecnologia. Este trabalho busca, também, despertar o interesse do aluno, que fica motivado ao perceber a aplicabilidade, no cotidiano, dos conceitos matemáticos aqui tratados.

Palavras-chave: Código de identificação, código de barras, divisibilidade. 


\begin{abstract}
FEOLA, L. S. S. Elementary topics of coding theory as a motivation for teaching divisibility. 2016. 117 f. Dissertação (Mestrado) - Instituto de Matemática e Estatística, Universidade de São Paulo, São Paulo, 2016.

The main objective of the work is to develop educational activities related to the basic concepts of divisibility of integral numbers, providing tools to math school teachers. The way those concepts were presented, creates the proper environment for the student to understand the mathematic logic behind the detection of typing errors in numerical codes, like for example: barcodes, RG, CPF and ISBN. It is noteworthy that the methodology used was inspired by problem solving and investigative activities - although, adjustments were made in order to comply with the content. Thus, it is expected that teachers will be able to provide opportunities to their students to develop skills and competences on the domain of elementary number theory, improve their knowledge on daily situations and explain the relationship between mathematics and technology. This work also seeks to arouse the interest of the students, who get motivated when they realize the applicability in daily life of the mathematical concepts covered here.
\end{abstract}

Keyword: Identification code, bar code, divisibility 


\section{LISTA DE ABREVIAÇÕES}

$\begin{array}{ll}\text { RG } & \text { Registro Geral } \\ \text { CPF } & \text { Cadastro de Pessoa Física } \\ \text { ISBN } & \text { International Standard Book Number } \\ \text { UPC } & \text { Universal Product Code } \\ \text { EAN-13 } & \text { European Article Numbering system } \\ \text { ANCC } & \text { Article Numbering Centre of China } \\ \text { SSP } & \text { Secretaria de Segurança Pública } \\ \text { GS1 } & \text { Antiga EAN International e o Uniform Code Council } \\ \text { PCN } & \text { Parâmetros Curriculares Nacionais }\end{array}$




\section{LISTA DE ILUSTRAÇÕES}

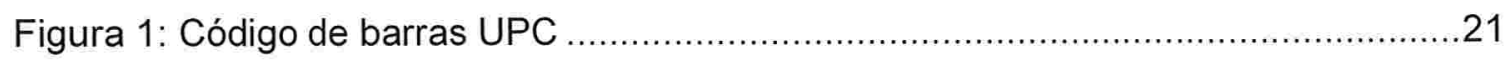

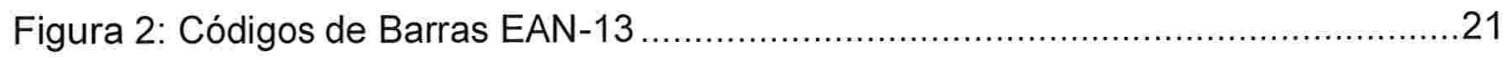

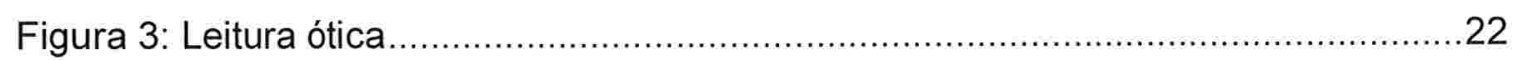

Figura 4: Representação de um algarismo no código de barras .................................23

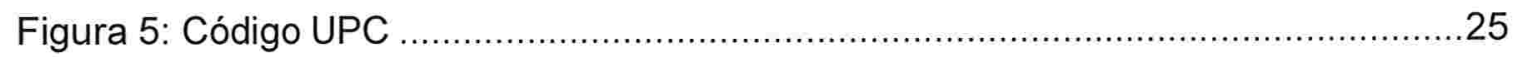



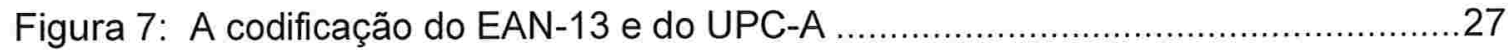

Figura 8:As informações contidas no código de barras EAN13 …............................31

Figura 9: Exemplo de código de barras para produto alimentício .................................34 


\section{LISTA DE TABELAS}

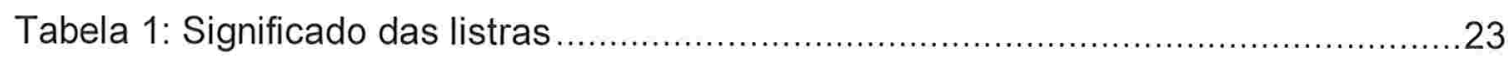

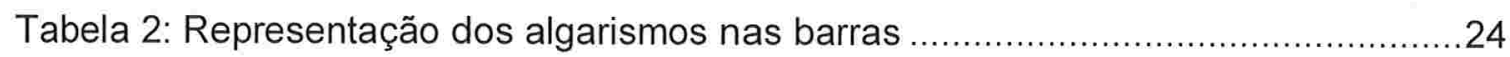

Tabela 3: Representação do lado esquerdo do EAN-13 ..........................................28

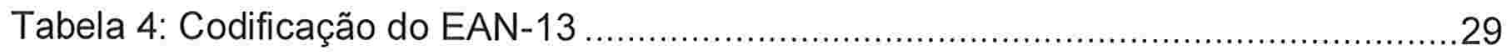

Tabela 5: Classificação para os diferentes tipos de problemas......................................56

Tabela 6: Etapas para a resolução de problemas ...........................................................61

Tabela 7: Etapas das atividades de investigação............................................................65 


\section{SUMÁRIO}

1 INTRODUÇÃO



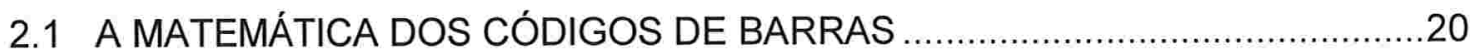

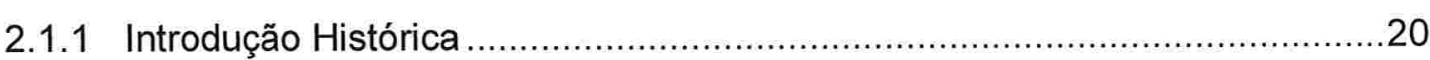

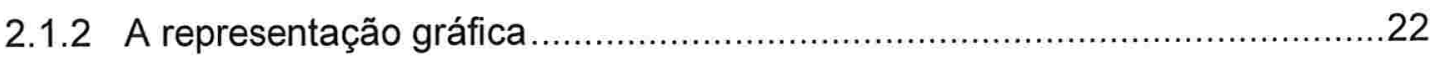

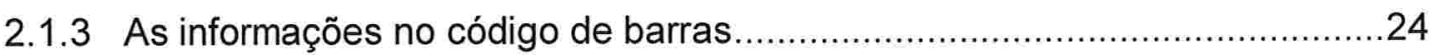

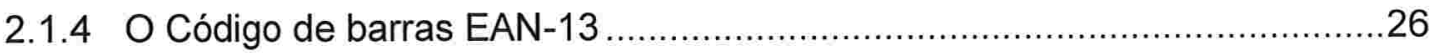

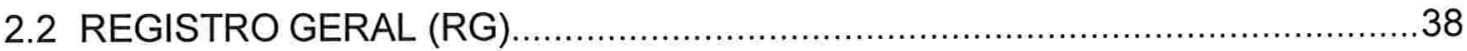

2.3 O CADASTRO DE PESSOAS FÍSICAS NA RECEITA FEDERAL - CPF ............40

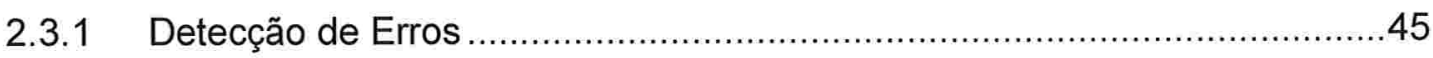



3 FUNDAMENTAÇÃO PARA ABORDAGEM PEDAGÓGICA ………......................4

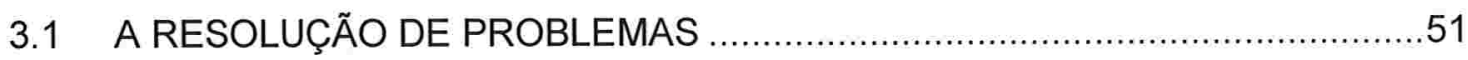

3.1.1 A Metodologia de Resolução de Problemas .............................................52

3.1.2 A Resolução de Problemas na Atividade Matemática .................................52

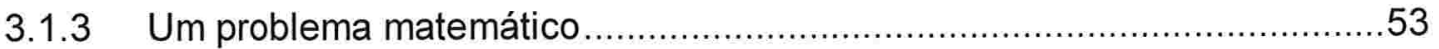

3.1.4 A Resolução de problemas na Educação Matemática .................................54

3.2 DA RESOLUÇÃO DE PROBLEMAS À INVESTIGAÇÃO MATEMÁTICA .........62

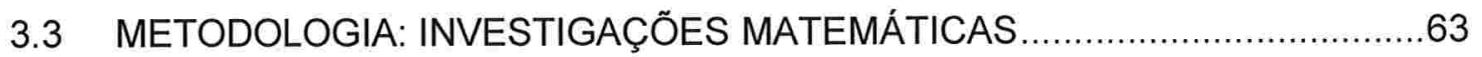

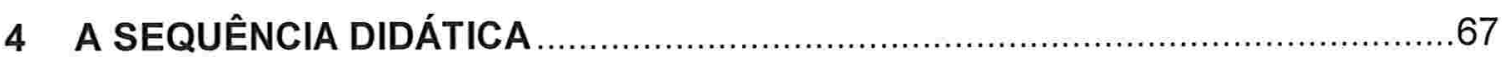

Atividade 1

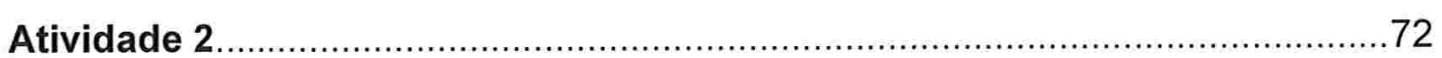

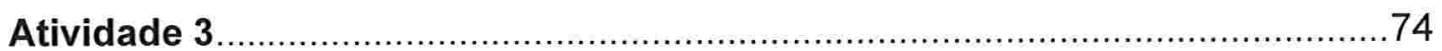

Atividade 4

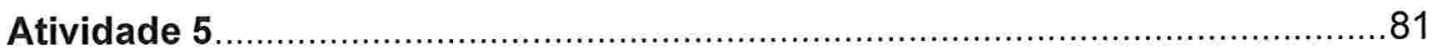

Atividade 6

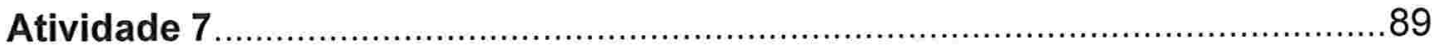



5.1 DESCRIÇÃO DOS RESULTADOS DAS ATIVIDADES APLICADAS ..................93 






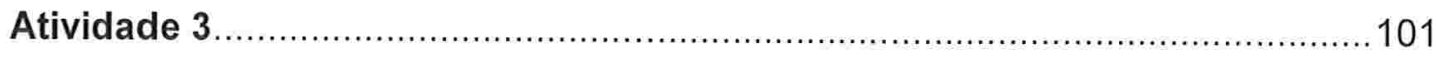

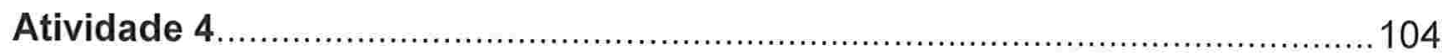

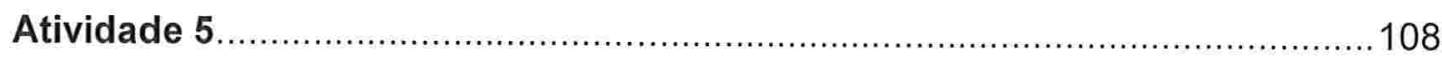

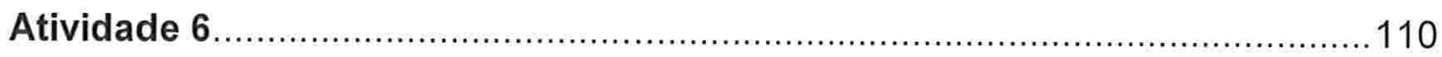



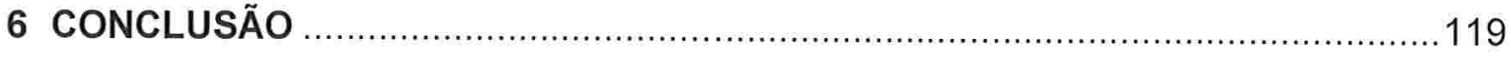






\section{INTRODUÇÃO}

Sabemos que o professor, enquanto pesquisador, questiona-se sobre sua atividade docente e procura alternativas para aprimorar sua prática no processo de aprendizagem dos alunos, buscando a eficiência na compreensão dos conteúdos propostos e motivando-os a prosseguir nos seus estudos.

As atividades na sala de aula estão sujeitas a inúmeros fatores que influenciam a aprendizagem como, por exemplo, o desinteresse dos alunos pelo conteúdo ou a forma como o conteúdo é exposto. Em se tratando da Matemática, o desinteresse do corpo discente está muitas vezes relacionado à dificuldade que eles encontram em associar as aplicações da disciplina ao cotidiano. Isto ocorre, pois a Matemática, geralmente, é percebida como algo pronto, extremamente formal, fechado, isolado e que não pode ser utilizada na vida prática.

Para exemplificar a afirmação acima, importa lembrar que conceitos como os de múltiplos, divisores e critérios de divisibilidade são abordados no início do Ensino Fundamental II, normalmente, sem aplicações relevantes, ou que façam sentido para o aluno.

Uma possibilidade de aumentar o interesse por esses conteúdos pode ser vista com a introdução de ideias iniciais sobre códigos de barras e detecção de erros nesse nível. Essa abordagem permitirá enfatizar o uso da Matemática na vida diária (mesmo quando não é explicitamente evidente), destacar a importância da interdisciplinaridade através das conexões entre Matemática e tecnologia e, sobretudo, motivar os alunos que já demonstram natural curiosidade por estes assuntos.

A dissertação incluirá no capítulo 2 uma exposição das bases Matemáticas dos temas a serem tratados, numa linguagem adequada à literatura do professor do ensino fundamental. Os tópicos pertinentes são os seguintes:

- A matemática dos códigos de barras e da detecção de erros; 
- Registro Geral (RG) e o Cadastro Nacional da Pessoa Física (CPF), como são formados e quais operações matemáticas fazem com que eventuais erros de digitação possam ser detectados;

- O Código de Verificação do ISBN (International Standard Book Number) e sua estrutura.

O capítulo 3 está organizado nas seguintes seções: a primeira traz uma abordagem sobre a fundamentação pedagógica, segundo as orientações dos Parâmetros Curriculares Nacionais, referentes ao ensino da Matemática no Ensino Fundamental; enquanto, a segunda e a terceira apresentam algumas ideias trazidas de uma breve análise sobre as metodologias da Resolução de Problemas e da Investigação Matemática.

No capítulo 4, os temas "Códigos de Barras" e "CPF" foram apresentados na forma de uma sequência didática, isto é, atividades realizadas em etapas, ligadas entre si, que possibilitarão ao aluno uma melhor compreensão dos conceitos envolvidos e o reconhecimento do papel crucial da matemática nos avanços tecnológicos.

O objetivo geral desse trabalho é levar ao professor de matemática instrumentos para a reflexão sobre como apresentar a divisibilidade por meio de situações de aplicação deste conteúdo nas práticas sociais (comércio, indústria, documentos) e explicitar as conexões entre Matemática, tecnologia e questões da vida prática.

Enquanto seu objetivo específico é apresentar alternativas para propiciar aos alunos situações didáticas nas quais as aplicações dos conceitos abordados, estimulem a busca por novos conhecimentos matemáticos, desenvolvendo o raciocínio lógico, mostrando a importância da Matemática no avanço da tecnologia e, além disso, ajudando a responder aos frequentes questionamentos sobre a utilidade da Matemática.

Portanto, o trabalho se justifica pela constante necessidade de propiciar aos alunos situações de aprendizagem que favoreçam o ensino de Matemática. Os livros didáticos buscam abordar o aspecto histórico da Matemática, aplicações no cotidiano e interdisciplinaridade. Porém, em alguns deles, na tentativa de contextualização, particularmente nos aspectos relacionados à Teoria de números, os problemas se tornam artificiais e de difícil compreensão. Em particular, os conceitos de múltiplos e divisores de 
números inteiros são explorados por meio de exercícios que, em geral, se baseiam na reprodução de técnicas que não fazem sentido para o aluno. 


\section{FUNDAMENTAÇÃO TEÓRICA}

Hoje em dia, os códigos numéricos de identificação e senhas estão presentes em diversos itens, como documentos, transações bancárias, na autenticação de ordens eletrônicas de pagamento, saques em caixas eletrônicos, pelos navegadores de Internet, entre outras situações.

Visando à confiabilidade e à segurança, esses códigos utilizam dígitos verificadores que consistem em um ou mais algarismos acrescentados ao número de identificação.

Os dígitos verificadores são obtidos através de determinados algoritmos que utilizam, normalmente, os próprios algarismos do código identificador. A elaboração desses algoritmos e a maneira como as informações são transmitidas dependem totalmente do uso de conceitos e procedimentos da Matemática.

A Teoria dos números é a parte da Matemática que estuda as propriedades dos números inteiros e conceitos relacionados a eles como divisibilidade e congruências. Essa área é considerada uma das mais antigas da Matemática e também uma das mais utilizadas em códigos numéricos de identificação e senhas. Dela resultam aplicações interessantes, tais como códigos de barras, código de verificação do ISBN, número do $\mathrm{CPF}$, número do RG, Criptografia, entre outros. Existe alguma literatura nesse sentido Tamarozzi (2001), Terada (2001), Santos (2013), Esquinca (2013) e Silva (2010).

O código de barras conhecido como EAN-13, por exemplo - presente em diversos setores como o alimentício, farmacêutico, na indústria e no comércio em geral -, pode ser identificado, rapidamente e sem riscos de erros, por aparelhos portáteis de leitura óptica. Esse tipo de código é uma representação gráfica de uma série de números, que vem impressa abaixo das barras.

Nessa série, estão contidas informações gerais sobre o produto, sendo que o último deles é destinado à detecção de possiveis erros e é determinado por um algoritmo matemático de fácil compreensão que envolve conceitos de multiplicação, adição e divisibilidade, conteúdos que são abordados no Ensino Fundamental II. 
Apresentaremos, a seguir, essa aplicação, sua função e os conteúdos matemáticos envolvidos na elaboração de seu algoritmo para a atribuição de dígitos verificadores, que possibilitam a detecção de eventuais erros de transmissão e digitação.

\subsection{A MATEMÁTICA DOS CÓDIGOS DE BARRAS}

Nesta seção serão abordados os tópicos principais que descrevem a Matemática utilizada nos códigos de barras dos sistemas UPC e EAN-13. É esperado que ao final deste tópico o leitor tenha conhecimento suficiente para compreender as atividades que envolvem o uso do código de barras.

\subsubsection{Introdução Histórica}

A criação dos códigos de barras é atribuída a Joseph Woodland e Bernard Silver, pelo pedido de patente em 1952. O código era formado por circunferências concêntricas de espessura variável, mas ainda não existia a leitura a laser, e os computadores, para fazerem a leitura, eram muito grandes.

Já o código de barras com listras verticais pretas e brancas surgiu em 1970. A empresa de consultoria McKinsey \& Company com a Uniform Grocery Product Code Council definiram um formato numérico para identificar produtos e precisavam de um código que atendesse a definição. Solicitaram a várias empresas o desenvolvimento desse código e a proposta escolhida foi a da empresa IBM cujo autor foi George J. Laurer.

Esse código ficou conhecido como UPC (Universal Product Code), foi adotado nos Estados Unidos e no Canadá e usado pela primeira vez, com leitura ótica, em um caixa de supermercado no estado de Ohio (Estados Unidos) em junho de 1974.

O primeiro produto com um código de barras digitalizado por um scanner laser foi uma goma de mascar, item escolhido aleatoriamente por um cliente. A embalagem desse 
produto está em exposição no Museu "The National Museum of American" como o primeiro produto com código de barras UPC comercializado com scanner.

Desde então, iniciou-se a informatização em compras de supermercados através da utilização dos códigos de barras. Essa tecnologia possibilitou a rapidez e o acompanhamento das vendas de milhares de produtos em diversos estabelecimentos comerciais e rapidamente migrou para outras áreas.

O UPC consistia numa sequência de 12 algarismos, traduzidos para listras brancas e pretas alternadas e de espessura variável, como pode ser observado na figura.

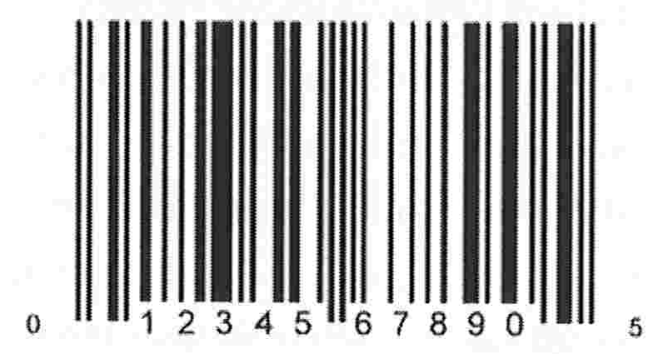

Figura 1: Código de barras UPC

Para que se pudesse difundir o sistema a outros países, foi solicitado a Laurer que ampliasse o código possibilitando identificar também o país de origem do produto. Tendo o UPC-A como base, ele criou, então, um novo código, o EAN (European Article Numbering system), com 13 algarismos, que começou a ser utilizado a partir de dezembro de 1976. Esse código é conhecido como EAN-13 e pode ser observado um exemplo na Figura 2 abaixo:

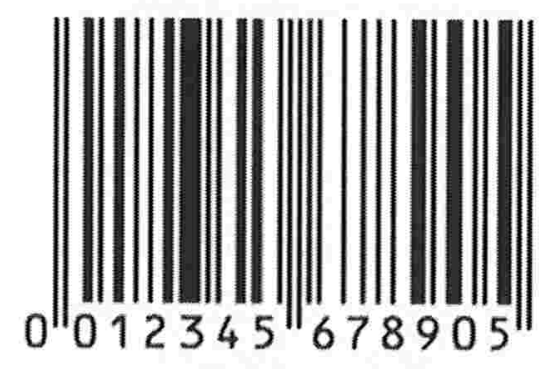

Figura 2: Códigos de Barras EAN-13 
Esse sistema é utilizado por muitos países, sendo que alguns o renomearam. Por exemplo, na China é conhecido por ANCC (Article Numbering Centre of China).

\subsubsection{A representação gráfica}

Um código de barras UPC é uma representação gráfica, formada por listras brancas e pretas alternadas, dos 12 algarismos que estão posicionados abaixo dela. Esses algarismos não são lidos pela máquina, são utilizados para leitura e digitação manual, caso ocorra algum problema na leitura ótica.

A leitura ótica do código é feita por um tipo de scanner, que emite uma luz vermelha percorrendo todas as listras, conforme exemplo da Figura 3. Ela identifica se a listra reflete uma luz ou nenhuma. Listras que não refletem luz (pretas) são lidas como 1 e as listras que refletem luz (brancas) são consideradas como 0. Essas informações capturadas pelo scanner são processadas pelo computador que lê os algarismos em numeração binária.

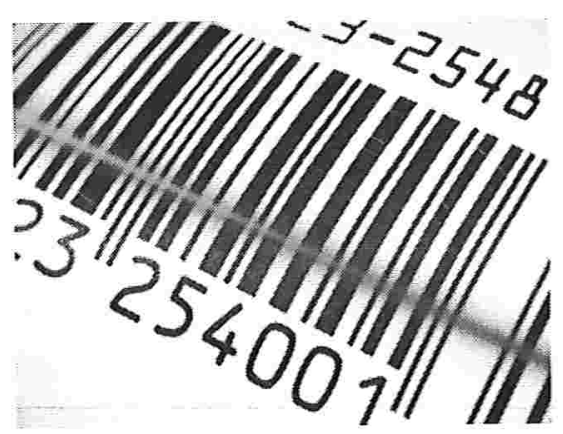

Figura 3: Leitura ótica

Fonte: http://redeglobo.globo.com/globociencia/noticia/2011/11/daastronomia-telecomunicacao-como-luz-e-aplicada-na-tecnologia.html

As listras mais compridas, que são as quatro primeiras, as quatro do meio e as quatro últimas, têm apenas a função de separar os algarismos em lado esquerdo e lado direito do código.

As listras que compõem o código, tanto as brancas quanto as pretas, possuem quatro espessuras diferentes, assim definidas: fina, média, grossa e muito grossa. Para 
indicar cada tipo de listra foram atribuídos os símbolos 0 ou 1 de acordo com a cor e espessura, vejamos a Tabela 1:

\begin{tabular}{|c|c|c|c|c|}
\hline Listras & Fina & Média & Grossa & $\begin{array}{c}\text { Muito } \\
\text { Grossa }\end{array}$ \\
\hline Preta & 1 & 11 & 111 & 1111 \\
\hline Branca & 0 & 00 & 000 & 0000 \\
\hline
\end{tabular}

Tabela 1: Significado das listras

Fonte: Polcino Milies, Cesar. A Matemática dos Códigos de Barras

A representação gráfica de qualquer um dos 12 algarismos do código é composta por quatro dessas listras alternadas, de tal forma que todos os algarismos tenham a mesma largura. Para isso, é atribuída uma sequência de sete símbolos iguais a 0 ou 1. Tomando por exemplo a Figura 4, o número 4 é representado do lado direito pela sequência 1011100, que é formado por uma listra preta fina (1), uma branca fina (0), uma preta grossa (111), uma branca média (00).

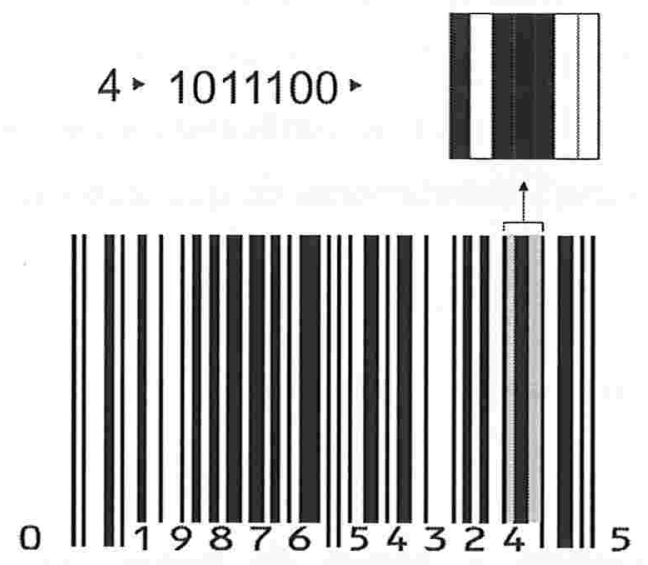

Figura 4: Representação de um algarismo no código de barras

O código de barras de um produto pode ser passado na leitura ótica em qualquer posição. Para que a máquina leitora reconheça se está lendo primeiro o lado direito ou esquerdo, a codificação de um dado algarismo, à direita é obtida da sua codificação à esquerda, trocando-se os símbolos 0 por 1 e vice-versa. Isto pode ser observado na Tabela 2: 


\begin{tabular}{|c|c|c|}
\hline Algarismo & $\begin{array}{c}\text { Lado } \\
\text { esquerdo }\end{array}$ & $\begin{array}{c}\text { Lado } \\
\text { direito }\end{array}$ \\
\hline 0 & 0001101 & 1110010 \\
1 & 0011001 & 1100110 \\
2 & 0010011 & 1101100 \\
3 & 0111101 & 1000010 \\
4 & 0100011 & 1011100 \\
5 & 0110001 & 1001110 \\
6 & 0101111 & 1010000 \\
7 & 0111011 & 1000100 \\
8 & 0110111 & 1001000 \\
9 & 0001011 & 1110100 \\
\hline
\end{tabular}

Tabela 2: Representação dos algarismos nas barras

Fonte: Polcino Milies, Cesar. A Matemática dos Códigos de Barras.

Podemos observar que cada sequência do lado esquerdo tem uma quantidade impar de símbolos iguais a 1, por conseguinte, do lado direito uma quantidade par de simbolos iguais a 1. Desta forma, verificando a paridade de cada sequência, a máquina consegue reconhecer imediatamente de que lado está lendo o código.

\subsubsection{As informações no código de barras}

Ao observarmos o código de barras, na Figura 5, verificamos que sua representação gráfica corresponde ao número: 034455667785. 


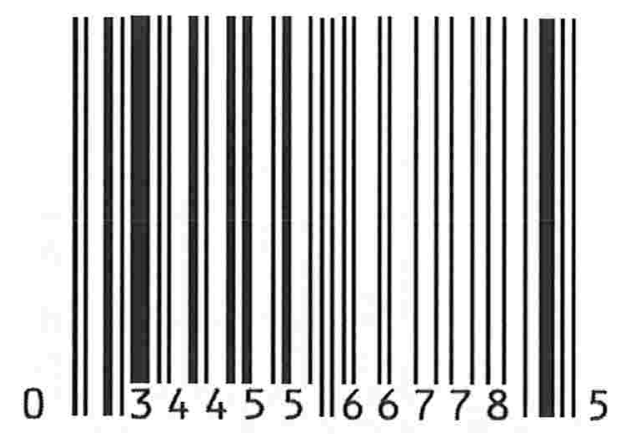

Figura 5: Código UPC

Todo código do sistema UPC tem esse formato:

$a_{1}-a_{2} a_{3} a_{4} a_{5} a_{6}-a_{7} a_{8} a_{9} a_{10} a_{11}-a_{12}$

O primeiro algarismo do sistema $\left(a_{1}\right)$ indica o tipo de produto classificado. Por exemplo, o número 0 é atribuído a produtos de consumo usuais; o número 1 está reservado para uso futuro; o 2 para produtos a serem pesados na loja e os começados por 3 são remédios e outros itens relacionados à saúde.

Os cinco algarismos seguintes ( $\left.a_{2} a_{3} a_{4} a_{5} a_{6}\right)$ são destinados à empresa fabricante e os próximos cinco ( $\left.a_{7} a_{8} a_{9} a_{10} a_{11}\right)$ são do próprio produto. O último número $\left(a_{12}\right)$ é um dígito de verificação que é atribuído ao código através de um algoritmo, visando a detectar possiveis erros de transmissão e de digitação dos seus algarismos. A figura abaixo ilustra a posição das informações contidas no código UPC. 


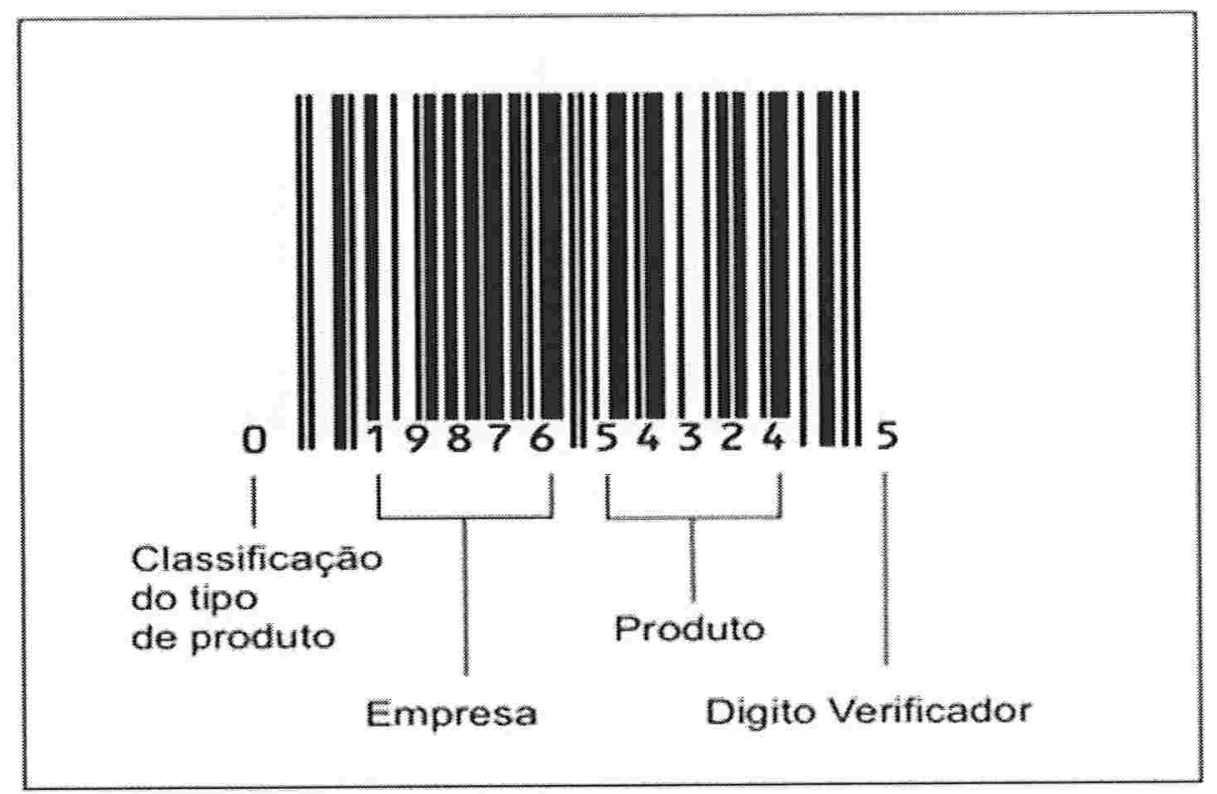

Figura 6: Informações contidas no Código UPC

\subsubsection{O Código de barras EAN-13}

Como já dissemos, o sistema de código de barras EAN-13 foi elaborado para expandir o uso dos códigos de barras do sistema UPC para outros países, além dos Estados Unidos e Canadá.

O processo de elaboração do sistema EAN-13 (European Article Numbering system) consistiu em acrescentar aos códigos de barras UPC mais um algarismo a frente dos 12 já existentes. Dessa forma, o novo sistema utilizaria 13 algarismos para a codificação das informações, mas havia a necessidade de se manter o mesmo padrão de tamanho dos códigos de barras do sistema UPC.

Além disso, deveria ser possivel a leitura ótica de códigos de barras de ambos os sistemas (UPC e EAN-13) por uma mesma máquina leitora. A solução encontrada pode ser observada na Figura 7 e consistiu em: 
- Para os países que já utilizavam o sistema UPC, Estados Unidos e Canadá, foi atribuído o número "0" ao primeiro algarismo dos códigos de barras de produtos registrados por eles e mantida a codificação das informações.

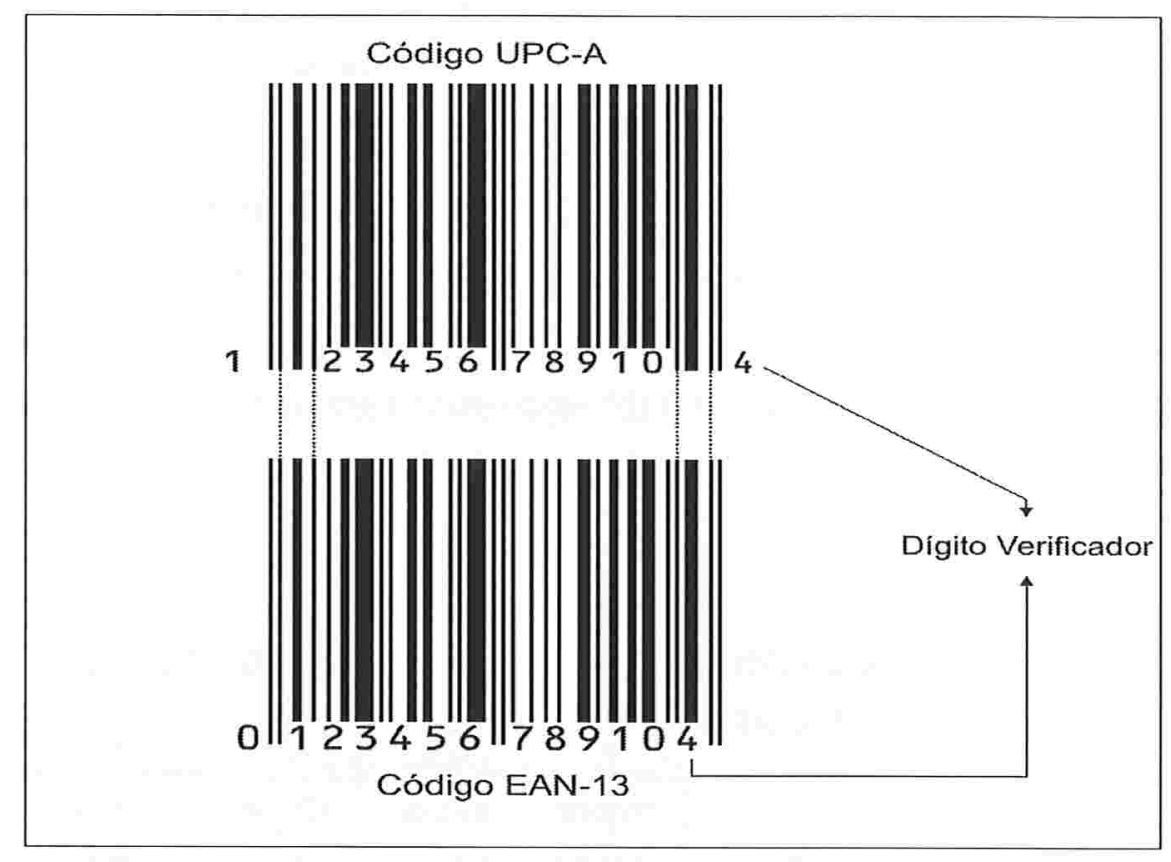

Figura 7: A codificação do EAN-13 e do UPC-A

- No sistema EAN 13, não foram feitas modificações do lado direito do código, preservando a estrutura para que a leitora continuasse a detectar o lado que está lendo.

- Como um único algarismo não seria suficiente para se distinguir vários países, no sistema EAN13, era necessário adicionar outro dígito, sem estender a representação gráfica. Sendo assim, o algarismo inicial não é representado nas barras, apenas na sequência numérica abaixo delas.

- Para a codificação do algarismo inicial, foi definido que cada algarismo do lado esquerdo pode-se escrever de duas formas, usando um número par ou ímpar de símbolos iguais a 1. Decidir qual expressão será utilizada é feita a partir do algarismo inicial, não representado nas barras, mas que fica definido implicitamente pela escolha realizada, ou seja, a codificação do lado esquerdo 
depende do valor do algarismo inicial que orientará a codificação dos outros seis.

Exemplo (de codificação):

Suponhamos que o código de um determinado produto seja:

$$
\text { 3-645732-812698 }
$$

Como o algarismo inicial é 3 , ao consultarmos a tabela abaixo, observamos que devemos representar o 6 ( $1^{\circ}$ algarismo do lado esquerdo) com um número ímpar de símbolos iguais a $1 ; 04$ ( $2^{\circ}$ algarismo) com número ímpar de símbolos iguais a 1 ; o $5\left(3^{\circ}\right.$ algarismo) com número par de símbolos iguais a 1; o 7 (4 algarismo) com número par de símbolos iguais a 1; o $3\left(5^{\circ}\right.$ algarismo) com número par de símbolos iguais a 1 e o 2 (6º algarismo) com número ímpar de símbolos iguais a 1.

\begin{tabular}{|c|c|c|c|c|c|c|}
\hline \multirow{2}{*}{$\begin{array}{c}\text { Algarismo } \\
\text { inicial }\end{array}$} & \multicolumn{6}{|c|}{ Algarismos do lado esquerdo } \\
\cline { 2 - 7 } & $1^{\circ}$ & $2^{\circ}$ & $3^{\circ}$ & $4^{\circ}$ & $5^{\circ}$ & $6^{\circ}$ \\
\hline 0 & impar & impar & impar & impar & Impar & impar \\
\hline 1 & impar & impar & par & impar & par & par \\
\hline 2 & imoar & impar & par & par & impar & par \\
\hline 3 & impar & impar & par & par & par & ímpar \\
\hline 4 & impar & par & Impar & Impar & par & par \\
\hline 5 & impar & par & par & impar & impar & par \\
\hline 6 & impar & par & par & par & impar & impar \\
\hline 7 & impar & par & impar & par & impar & par \\
\hline 8 & impar & par & impar & par & par & impar \\
\hline 9 & impar & par & par & impar & par & impar \\
\hline
\end{tabular}

Tabela 3: Representação do lado esquerdo do EAN-13

Fonte: Polcino Milies, Cesar. A Matemática dos Códigos de Barras.

A seguir, definido se a codificação do algarismo terá quantidade par ou ímpar de símbolos iguais a 1 , a representação gráfica será feita de acordo com a tabela 4, isto é: 


$$
\begin{aligned}
6 & \Rightarrow \text { ímpar } \Rightarrow 0101111, \\
4 & \Rightarrow \text { ímpar } \Rightarrow 0100011 \\
5 & \Rightarrow \text { par } \Rightarrow 0111001 \\
7 & \Rightarrow \text { par } \Rightarrow 0010001 \\
3 & \Rightarrow \text { par } \Rightarrow 0100001 \\
2 & \Rightarrow \text { ímpar } \Rightarrow 0010011
\end{aligned}
$$

\begin{tabular}{|c|c|c|c|}
\hline \multirow{2}{*}{ Algarismo } & \multicolumn{2}{|c|}{ Lado esquerdo } & \multirow{2}{*}{ Lado direito } \\
\cline { 2 - 3 } & impar & par & \\
\hline 0 & 0001101 & 0100111 & 1110010 \\
\hline 1 & 0011001 & 0110011 & 1100110 \\
\hline 2 & 0010011 & 0011011 & 1101100 \\
\hline 3 & 0111101 & 0100001 & 1000010 \\
\hline 4 & 0100011 & 0011101 & 1011100 \\
\hline 5 & 0110001 & 0111001 & 1001110 \\
\hline 6 & 0101111 & 0000101 & 1010000 \\
\hline 7 & 0111011 & 0010001 & 1000100 \\
\hline 8 & 0110111 & 0001001 & 1001000 \\
\hline 9 & 0001011 & 0010111 & 1110100 \\
\hline
\end{tabular}

Tabela 4: Codificação do EAN-13

Fonte: Polcino Milies, Cesar. A Matemática dos Códigos de Barras.

Tomando por exemplo o número 6, representado pela sequência 0101111, será formado, de acordo com a tabela 1, por uma listra branca fina (0), uma preta fina (1), uma branca fina (0) e uma preta muito grossa (1111).

Vejamos um exemplo:

A identificação numérica do código de barras de um achocolatado produzido no Brasil é 7894321 722016. Na representação gráfica, onde podemos representar apenas 12 algarismos, o algarismo inicial 7 não está representado nas barras. Como a máquina leitora "sabe" qual é o algarismo inicial? 
Suponhamos que os primeiros seis algarismos foram representados nas barras da seguinte forma:

$$
\begin{aligned}
& 8 \Rightarrow 0110111 \Rightarrow \text { impar } \\
& 9 \Rightarrow 0010111 \Rightarrow \text { par } \\
& 4 \Rightarrow 0100011 \Rightarrow \text { ímpar } \\
& 3 \Rightarrow 0100001 \Rightarrow \text { par } \\
& 2 \Rightarrow 0010011 \Rightarrow \text { ímpar } \\
& 1 \Rightarrow 0100111 \Rightarrow \text { par }
\end{aligned}
$$

Logo, a sequência de paridade é: Impar, par, impar, par, impar, par, que corresponde à linha 7 da tabela3. Portanto, o algoritmo inicial é o 7.

No código EAN 13, estão codificadas as seguintes informações:

- Os primeiros dois ou três algarismos do código identificam o país em que o

- código de barras do produto foi registrado. Por exemplo, os códigos dos produtos registrados no Brasil começam com 789.

- Os próximos quatro ou cinco algarismos do código (dependendo de quantos foram utilizados para a identificação do país) indicam o fabricante do produto.

- A sequência formada pelos cinco últimos algarismos indica o próprio produto.

- O último algarismo é o dígito verificador. 




Figura 8: As informações contidas no código de barras EAN13

\subsubsection{A Detecção de Erros}

Para melhor compreensão do processo de detecção de erros, inicialmente, será abordado o algoritmo utilizado para a atribuição de um dígito verificador a um código de barras do sistema EAN-13 e também do UPC.

O algarismo do dígito verificador de um código de barras é determinado através de operações matemáticas realizadas com os próprios algarismos do código. Os conceitos matemáticos utilizados na atribuição de um dígito verificador a um código de barras EAN-13 estão descritos abaixo.

O código de barras de um produto no sistema EAN-13 pode ser escrito no seguinte formato: 
Como já dissemos, os primeiros doze algarismos identificam o país onde o produto foi cadastrado, o fabricante e o próprio produto. Esse número de identificação do produto é determinado por uma autoridade classificatória em cada país.

Já o último algarismo do código de barras $\left(a_{13}\right)$ é um dígito verificador, determinado através de um algoritmo, que possibilita a detecção de eventuais erros de transmissão e digitação.

Denotaremos o décimo terceiro algarismo, o dígito verificador, por "v".

A seguir será apresentado o algoritmo, utilizado pelo sistema EAN-13, para determinar o dígito verificador.

Multiplique os doze primeiros algarismos ( $\left.a_{1} a_{2} a_{3} a_{4} a_{5} a_{6} a_{7} a_{8} a_{9} a_{10} a_{11} a_{12}\right)$, nessa ordem, pela base de cálculo $\{1,3,1,3,1,3,1,3,1,3,1,3\}$.

Some os produtos obtidos. Representaremos por $\mathrm{S}$ a soma obtida.

Divida S (soma obtida) por 10.

O algarismo do dígito verificador (v) é o valor que deve ser adicionado a $S$ (soma obtida) para que o resultado seja um múltiplo de 10 , isto é, o número $S+v$ deve ser múltiplo de 10.

Vejamos um exemplo:

- Considerando o código de barras da Figura 8, temos que seu número de identificação é 7-894321-72201.

- Veremos como foi determinado o dígito verificador desse código de barras, que é o algarismo 6 (como podemos observar na figura).

- Chamando esse dígito de " $v$ " e aplicando o algoritmo, temos:

- Escrevemos a sequência dos 12 algarismos do código e abaixo deles, começando pelo primeiro, a sequência $1,3,1,3,1,3, \ldots$

\begin{tabular}{|l|l|l|l|l|l|l|l|l|l|l|l|}
\hline 7 & 8 & 9 & 4 & 3 & 2 & 1 & 7 & 2 & 2 & 0 & 1 \\
\hline 1 & 3 & 1 & 3 & 1 & 3 & 1 & 3 & 1 & 3 & 1 & 3 \\
\hline
\end{tabular}

- Efetuamos as multiplicações correspondentes e somamos os produtos obtidos, obtemos:

- $S=7+24+9+12+3+6+1+21+2+6+0+3$

- $S=94$ 
- Dividimos o resultado da soma (S) por 10, teremos:

- $94=9 \times 10+4$

- Logo, o dígito verificador é igual a $6(10-4)$. Vejamos que $94+6=90$ (múltiplo de 10).

O algoritmo utilizado no sistema UPC é praticamente o mesmo. Como ele utiliza apenas 12 algarismos para codificação, a multiplicação dos onze primeiros algarismos ( $\left.a_{1} a_{2} a_{3} a_{4} a_{5} a_{6} a_{7} a_{8} a_{9} a_{10} a_{11}\right)$, nessa ordem, é feita pela base de cálculo $\{3,1,3,1,3,1,3,1,3,1,3\}$. A soma dos produtos obtidos é dividida por 10 e o dígito verificador será o valor necessário para que adicionado à soma obtida resulte em um múltiplo de 10 .

\subsubsection{A verificação dos erros}

Ao ser realizada a leitura ótica de um código de barras, pode ocorrer um problema caso a embalagem esteja úmida ou amassada, sendo assim o operador de caixa deve digitar a sequência numérica que se encontra abaixo das listras.

Neste momento pode ocorrer, eventualmente, algum erro na digitação dos algarismos do número de identificação. Segundo Polcino Milies (2009), autores como D.F. Beckley e J. Verhoeff pesquisaram sistematicamente os erros cometidos por humanos. O tipo de erro mais frequente, com $79 \%$ de ocorrência, foi o "erro único", isto é, quando um digitador comete apenas um erro de digitação, trocando um dos algarismos $a_{i}$ por outro valor. O outro tipo de erro, com $10,2 \%$ de ocorrência, consiste em digitar todos os algarismos corretamente, mas trocar a ordem de dois algarismos consecutivos. Serão abordados estes dois tipos de erro e o processo utilizado para a detecção.

Exemplo 3: Consideremos o código de barras da figura abaixo: 




Figura 9: Exemplo de código de barras para produto alimentício

Suponhamos que não tenha sido possível efetuar a leitura ótica do código de barras e ao digitar o número de identificação 7891000072998 tenha sido cometido um único erro de digitação, no oitavo algarismo do código. Dessa forma, o número foi assim transmitido: 7891000472998 . O computador ao receber o número aplicaria o algoritmo:

- $S=7+3 \times 8+9+3 \times 1+0+0+0+3 \times 4+7+3 \times 2+9+3 \times 9+8$

- $S=7+24+9+3+12+7+6+9+27+8$

- $S=112$

Como a soma obtida não é múltiplo de 10 , o computador emitiria um sinal sonoro alertando a ocorrência de algum erro. Observe que, sempre que ocorrer um único erro na digitação ele será detectado, o mesmo não se pode afirmar caso seja cometido mais que um erro na digitação do código.

Suponhamos que além do erro cometido na digitação do oitavo algarismo, ocorresse outro também, no quinto algarismo, e o código fosse transmitido assim: 7891800472998. Novamente, o computador aplicaria o algoritmo:

- $S=7+3 \times 8+9+3 \times 1+8+0+0+3 \times 4+7+3 \times 2+9+3 \times 9+8$

- $S=7+24+9+3+8+12+7+6+9+27+8$

- $S=120$

Como a soma obtida é múltiplo de 10 , o erro não seria detectado.

Observe que o erro não foi detectado, pois foram cometidos dois erros que se "compensaram" mutuamente.

A seguir, abordaremos outro tipo de erro, já mencionado, que consiste em digitar todos os algarismos corretamente, mas trocar a ordem de dois algarismos consecutivos.

\section{Exemplo 4:}


Supondo que ao digitar o número de identificação: 7891000072998, do exemplo anterior, seja cometido o erro de trocar a ordem de dois algarismos consecutivos do código. O código transmitido tenha sido: 7891000079298 . Ao ser efetuado o algoritmo, o sistema obteria:

I $S=7+3 \times 8+9+3 \times 1+0+0+0+3 \times 0+7+3 \times 9+2+3 \times 9+8$

- $S=7+24+9+3+0+7+27+2+27+8$

- $S=114$

O erro seria detectado, pois a soma obtida não é múltiplo de 10.

Logo, o computador emitiria um sinal sonoro alertando que foi cometido algum erro.

Exemplo 5:

Suponhamos agora que ao digitar o código 7891000072998, seja cometido o erro de trocar a ordem de dois algarismos consecutivos do código. E o código transmitido tenha sido: 7891000027998 . Ao efetuar a verificação, teríamos:

- $S=7+3 \times 8+9+3 \times 1+0+0+0+0+2+3 \times 7+9+3 \times 9+8$

- $S=7+24+9+3+0+2+21+9+27+8$

- $S=110$

O erro não seria detectado, pois o valor da soma obtida é múltiplo de 10.

Com esse exemplo, podemos constatar que o sistema utilizado nos códigos de barras EAN-13 e UPC não possibilita a detecção de todo erro de troca de dois algarismos consecutivos.

Demonstraremos que a troca de dois algarismos consecutivos $a_{i}$ e $a_{i+1}$ não é detectada no sistema de codificação EAN-13 e pelo UPC, se e somente se $\left|a_{i}-a_{i+1}\right|=5$.

Suponhamos que um produto é identificado pela sequência: $\left\{a_{1}, \ldots, a_{i}, a_{i+1}, \ldots, a_{13}\right\}$ no sistema EAN-13 e considere a base de cálculo $\{1,3,1,3,1,3,1,3,1,3,1,3,1\}$. Suponhamos que $i$ seja ímpar.

Efetuamos as multiplicações correspondentes e seja $S$ a soma dos produtos obtidos, temos:

$$
S=1 a_{1}+3 a_{2}+\cdots+1 a_{i}+3 a_{i+1}+\cdots+a_{13}
$$

Como $S$ é múltiplo de 10 , então

$$
1 a_{1}+3 a_{2}+\cdots+1 a_{i}+3 a_{i+1}+\cdots+a_{13}=10 q \quad \text { (1) } \quad \text { com } q \in \mathbb{Z}
$$


Suponhamos que tenha ocorrido erro de digitação do tipo "troca de dois algarismos consecutivos" e que os algarismos de identificação tenham sido digitados nessa ordem: $\left\{a_{1}, \ldots, a_{i+1}, a_{i}, \ldots, a_{13}\right\}$. Calculamos os produtos pela base de cálculo e seja $S^{\prime}$ a soma obtida, logo

$$
S^{\prime}=1 a_{1}+3 a_{2}+\cdots+1 a_{i+1}+3 a_{i}+\cdots+a_{13}
$$

Suponha que o erro não seja detectado, então $S^{\prime}$ também é múltiplo de 10 , logo

$$
1 a_{1}+3 a_{2}+\cdots+1 a_{i+1}+3 a_{i}+\cdots+a_{13}=10 q^{\prime} \quad \text { (2) } \quad \text { com } q^{\prime} \in \mathbb{Z}
$$

Subtraímos a segunda equação da primeira, isto é,

$$
\begin{aligned}
1 a_{1}+3 a_{2}+\cdots+1 a_{i+1}+3 a_{i}+\cdots+a_{13} & =10 q^{\prime} \\
1 a_{1}+3 a_{2}+\cdots+1 a_{i}+3 a_{i+1}+\cdots+a_{13} & =10 q \\
2 a_{i}-2 a_{i+1} & =10 q^{\prime}-10 q
\end{aligned}
$$

Colocando em evidência os fatores comuns, temos:

$$
2\left(a_{i}-a_{i+1}\right)=10\left(q^{\prime}-q\right)
$$

Temos que $\left|a_{i}-a_{i+1}\right| \leq 9$, pois $a_{i}$ e $a_{i+1}$ são algarismos entre 0 e 9 , então:

$$
\left|a_{i}-a_{i+1}\right|=5
$$

Portanto, conclui-se que o erro de transposição adjacente não será detectado se, e somente se, $\left|a_{i}-a_{i+1}\right|=5$

Observe que no exemplo 5 o erro não foi detectado, pois o número base utilizado é 10 e temos que 10 é múltiplo de 2 e de 5 . Se o número base fosse um número primo, por exemplo 11 (foi escolhido por ser o primeiro primo acima de 10 e também por ser utilizado em vários algoritmos de detecção), o erro seria detectado. Utilizaremos o exemplo anterior, para mostrar esse resultado:

Consideremos os 12 algarismos iniciais do código: 789100007299. Aplicaremos o algoritmo para atribuirmos o dígito verificador considerando a base 11:

- Escrevemos a sequência dos 12 algarismos do código e abaixo deles, começando pelo primeiro, a sequência $1,3,1,3,1,3, \ldots$

\begin{tabular}{|l|l|l|l|l|l|l|l|l|l|l|l|}
\hline 7 & 8 & 9 & 1 & 0 & 0 & 0 & 0 & 7 & 2 & 9 & 9 \\
\hline 1 & 3 & 1 & 3 & 1 & 3 & 1 & 3 & 1 & 3 & 1 & 3 \\
\hline
\end{tabular}

- Efetuamos as multiplicações correspondentes e somamos os produtos obtidos, temos: 
- $S=7+3 \times 8+9+3 \times 1+0+0+0+0+7+3 \times 2+9+9 \times 3$

- $S=92$

- Dividimos o resultado da soma (S) por 11, teremos:

- $92=8 \times 11+4$

Logo, o dígito verificador é igual a $7(11-4)$. Vejamos que $92+7=99$ (múltiplo de 11).

- O código de barras com o dígito verificador, calculado com o número base 11 é: 7891000072997.

- Analisaremos agora o erro cometido no exemplo anterior, isto é, suponhamos que tenha sido digitado 7891000027997 ao invés de 7891000072997 . Ao ser efetuado o algoritmo, o sistema obteria:

- $S=7+3 \times 8+9+3 \times 1+0+0+0+0+2+3 \times 7+9+3 \times 9+7$

- $S=7+24+9+3+2+21+9+27+7$

- $S=109$

- Como a soma obtida não é múltiplo de 11, o erro seria detectado.

Todas as observações e exemplos considerados são casos particulares do seguinte resultado geral:

Teorema: (Capacidade de Detecção).

Sejam $m$ um inteiro positivo e uma base de cálculo $w=\left\{w_{1}, \ldots, w_{n}\right\}$. Suponhamos que um produto é identificado pela sequencia $\alpha=\left(a_{1}, \ldots, a_{i}, \ldots, a_{n}\right)$ onde assumimos que $(0 \leq$ $a_{i}<m$, para todo índice $\left.i, 1 \leq i \leq n\right)$ tal que:

$$
c=a_{1} w_{1}+a_{2} w_{2}+\cdots+a_{n} w_{n} \text { é um múltiplo de } m \text {. }
$$

Então:

1. Todo erro consistente numa única alteração na $i$ - ésima posição será detectado se e somente se $m d c\left(w_{i}, m\right)=1$

2. Todo erro de transposição da forma

$$
\ldots a_{i} \ldots a_{j} \ldots \rightarrow \cdots a_{j} \ldots a_{i} \ldots
$$

Será detectado se e somente se $m d c\left(w_{i}-w_{j}, m\right)=1$ 


\section{Demonstração}

1. Suponhamos inicialmente que o algarismo $a_{i}$ na posição $i$, foi trocado por outro valor $b_{i}$ e vamos denotar por $\beta$ o código resultante deste erro, isto é $\beta=$ $\left(a_{1}, \ldots, b_{i}, \ldots, a_{n}\right)$.

É claro que o erro não será detectado se e somente se $\alpha \cdot w-\beta . w$ é múltiplo de $m$. Mas

$$
\begin{aligned}
\propto w-\beta w & =\left(a_{1} w_{1}+\cdots+a_{i} w_{i}+\cdots+a_{n} w_{n}\right)-\left(a_{1} w_{1}+\cdots+b_{i} w_{i}+\cdots+a_{n} w_{n}\right)= \\
& =a_{i} w_{i}-b_{i} w_{i}=\left(a_{i}-b_{i}\right) w_{i}
\end{aligned}
$$

de modo que o erro não será detectado se e somente se, $\left(a_{i}-b_{i}\right) w_{i}$ é múltiplo de $m$.

Note inicialmente que, se $m d c\left(w_{i}, m\right)=1$, então $m$ divide $\left(a_{i}-b_{i}\right) w_{i}$ se e somente se $m$ divide $\left(a_{i}-b_{i}\right)$.

Como $a_{i}$ e $b_{i}$ são menores que $m$, a diferença $a_{i}-b_{i}$ (em valor absoluto) é menor que $m$. Logo $m$ divide $\left(a_{i}-b_{i}\right)$ se e somente se $a_{i}-b_{i}=0$, isto é, se e somente se $a_{i}=$ $b_{i}$.

Se a substituição de $a_{i}$ por $b_{i}$ for um erro, então $a_{i} \neq b_{i}$ e esse erro será detectado.

Se $m d c\left(w_{i}, m\right)=d \neq 1$ então escrevendo $w_{i}=t_{i} d$ e $m=k d$ temos que

$$
\left(a_{i}-b_{i}\right) \cdot w_{i}=\left(a_{i}-b_{i}\right) t_{i} d
$$

Logo, se $a_{i}-b_{i}=k$, por exemplo, temos $\left(a_{i}-b_{i}\right) w_{i}=k t_{i} d=t_{i} m$.

Este número é um múltiplo de $m$ e este erro não pode ser detectado.

2. Suponhamos agora que foi cometido um erro do tipo

$\propto=\cdots a_{i} \ldots a_{j} \ldots \rightarrow \alpha^{\prime}=\cdots a_{j} \ldots a_{i} \ldots$

Note que neste caso podemos calcular a diferença:

$\propto \cdot w-\alpha^{\prime} \cdot w=\left(a_{1} w_{1}+\cdots+a_{i} w_{i}+\cdots+a_{j} w_{j}+\cdots+a_{n} w_{n}\right)-\left(a_{1} w_{1}+\cdots+a_{j} w_{i}+\cdots+\right.$ $\left.a_{i} w_{j}+\cdots+a_{n} w_{n}\right)=\left(a_{i} w_{i}-a_{j} w_{i}+a_{j} w_{j}-a_{i} w_{j}\right)=a_{i}\left(w_{i}-w_{j}\right)-a_{j}\left(w_{i}-w_{j}\right)=$ $=\left(w_{i}-w_{j}\right) \cdot\left(a_{i}-a_{j}\right)$

Assim, esse erro só será detectado se $\left(w_{i}-w_{j}\right) .\left(a_{i}-a_{j}\right)$ for múltiplo de $m$.

Daqui em diante, o argumento é inteiramente análogo ao anterior.

\subsection{REGISTRO GERAL (RG)}


O Registro Geral (RG) ou carteira de identidade é um documento emitido pela Secretaria de Segurança Pública (SSP) de cada estado do Brasil. Este documento pode ser solicitado para todo cidadão nascido e registrado no Brasil e para nascidos no exterior, que sejam filhos de brasileiros.

O RG é utilizado para confirmar a identidade de um indivíduo e para solicitação de outros documentos. Ele é válido em todo território nacional e substitui o passaporte em viagens para a Argentina, Paraguai, Uruguai, Chile, Bolívia, Colômbia, Equador, Peru e Venezuela.

A carteira de identidade de uma pessoa, ou o $R G$, possui um número com oito algarismos e um dígito verificador (dígito que vem após o traço), que é utilizado para verificar a validade e a autenticidade do documento na transmissão ou digitação.

O dígito verificador se obtém através de operações básicas realizadas com os próprios algarismos do RG, envolvendo conceitos de múltiplos e de divisibilidade, conceitos que estão presentes no currículo de Matemática no início do Ensino Fundamental II.

Sendo assim, abordar, em sala de aula, os processos de formação do dígito verificador do RG, viabiliza ao aluno conhecer a aplicação de conteúdos matemáticos em temas do cotidiano.

O número do RG tem o seguinte formato:

$$
a_{1} a_{2} a_{3} a_{4} a_{5} a_{6} a_{7} a_{8}-V
$$

A seguir será apresentado o algoritmo que possibilita determinar o dígito verificador do $R G$.

a) Multiplique os oito primeiros dígitos $\left(a_{1} a_{2} a_{3} a_{4} a_{5} a_{6} a_{7} a_{8}\right)$, nessa ordem, pela base de cálculo $\{9,8,7,6,5,4,3,2\}$.

b) Some os produtos obtidos.

C) Divida a soma obtida por 11 .

d) O dígito verificador é o número que deverá ser subtraído da soma obtida para que ela seja múltipla de 11 , ou seja, ele $(V)$ é o próprio resto dessa divisão.

Se o resto for igual a 10 , então o dígito verificador será a letra " $X$ ".

Vejamos um exemplo: 
Supondo que o número da carteira de identidade, ou RG, de uma pessoa seja 66655544-8. Vejamos o cálculo do dígito verificador que, como podemos observar, é igual a 8 .

1. Posicionando os algarismos da base de cálculo abaixo dos do RG, teremos:

\begin{tabular}{|l|l|l|l|l|l|l|l|}
\hline 6 & 6 & 6 & 5 & 5 & 5 & 4 & 4 \\
\hline $\mathbf{9}$ & $\mathbf{8}$ & $\mathbf{7}$ & $\mathbf{6}$ & $\mathbf{5}$ & $\mathbf{4}$ & $\mathbf{3}$ & $\mathbf{2}$ \\
\hline
\end{tabular}

2. Efetuando as multiplicações correspondentes e somando os produtos obtidos, obteremos:

- $S_{1}=6 \times 9+6 \times 8+6 \times 7+5 \times 6+5 \times 5+5 \times 4+4 \times 3+4 \times 2$

- $S_{1}=54+48+42+30+25+20+12+8$

- $S_{1}=239$

Dividindo o resultado da soma $\left(\mathrm{S}_{1}\right)$ por 11 , teremos:

- $239=21 \times 11+8$

Logo, o dígito verificador é igual a 8 .

\subsection{O CADASTRO DE PESSOAS FÍSICAS NA RECEITA FEDERAL - CPF}

O CPF de uma pessoa, no Brasil, é o registro de um cidadão na Receita Federal brasileira. Todos os contribuintes (pessoas físicas brasileiras ou estrangeiras com negócios no Brasil) devem ter esse registro, pois é utilizado em diversas situações, principalmente, em operações financeiras, como aberturas de contas bancarias e etc.

O número do CPF é constituído por 11 algarismos, sendo que os dois últimos são dígitos de controle, que possibilitam a verificação automática com o objetivo de detectar possíveis erros de digitação, o que o torna um documento confiável.

Os dígitos de controle, ou verificação, são determinados através de operações básicas realizadas com os próprios algarismos do CPF, envolvendo conceitos de múltiplos e de divisibilidade. Esses conceitos são parte integrante do currículo de Matemática no início do Ensino Fundamental II, logo, o mecanismo de segurança 
utilizado no CPF é um tema atual que possibilita ao aluno vivenciar a aplicação de conteúdos abordados em sala de aula.

$O$ CPF tem o seguinte formato:

$A_{1} A_{2} A_{3} A_{4} A_{5} A_{6} A_{7} A_{8} R-V_{1} V_{2}$

Os oito primeiros algarismos se referem ao número de inscrição da pessoa física no Cadastro Individual do Contribuinte. O nono algarismo $(R)$ indica a região onde foi efetuada a inscrição, por exemplo, inscrições efetuadas em São Paulo terão o dígito 8 . E os dois últimos algarismos do CPF, ou seja, o décimo $\left(V_{1}\right)$ e o décimo primeiro $\left(V_{2}\right)$ são dígitos de controle ou de verificação.

A seguir serão apresentados dois algoritmos que possibilitam determinar os dígitos de controle do CPF. Um deles consiste em:

- Cálculo do primeiro dígito de controle $\left(\mathrm{V}_{1}\right)$ :

Multiplique os 9 primeiros dígitos $\left(A_{1} A_{2} A_{3} A_{4} A_{5} A_{6} A_{7} A_{8} R\right)$, nessa ordem, pela base de cálculo $\{1,2,3,4,5,6,7,8,9\}$, e some os produtos obtidos. Divida a soma obtida por 11. O primeiro dígito de controle é o número que deverá ser subtraído da soma obtida para que ela seja múltiplo de 11 , ou seja, ele $\left(V_{1}\right)$ é o próprio resto dessa divisão.

- Cálculo do segundo dígito de controle $\left(\mathrm{V}_{2}\right)$ :

O procedimento é semelhante ao utilizado anteriormente. Inicialmente, acrescente ao número do CPF o décimo dígito obtido $\left(\mathrm{V}_{1}\right)$, e multiplique os 10 primeiros dígitos $\left(A_{1} A_{2} A_{3} A_{4} A_{5} A_{6} A_{7} A_{8} R V_{1}\right)$, nessa ordem, pela base de cálculo \{0, 1, 2, 3, 4, 5, $6,7,8,9\}$, e some os produtos obtidos. Divida a soma obtida por 11 . O segundo dígito de controle $\left(\mathrm{V}_{2}\right)$ é o resto dessa divisão.

Vamos calcular os dígitos de controle do CPF que tem os seguintes 9 primeiros algarismos: 444.555 .666

Cálculo do primeiro dígito de controle $\left(\mathrm{V}_{1}\right)$ :

1. Posicionar os algarismos da base de cálculo abaixo dos do CPF, teremos:

\begin{tabular}{|l|l|l|l|l|l|l|l|l|}
\hline 4 & 4 & 4 & 5 & 5 & 5 & 6 & 6 & 6 \\
\hline 1 & 2 & 3 & 4 & 5 & 6 & 7 & 8 & 9 \\
\hline
\end{tabular}

2. Efetuando os produtos correspondentes e somando, obtemos: 
- $\mathrm{S}_{1}=1 \times 4+2 \times 4+3 \times 4+4 \times 5+5 \times 5+6 \times 5+7 \times 6+8 \times 6+9 \times 6$

- $\mathrm{S}_{1}=243$

3. Dividindo o resultado da soma $\left(\mathrm{S}_{1}\right)$ por 11 , teremos:

- $243=11 \times 22+1$

4. Logo, o primeiro dígito verificador será o algarismo 1, portanto:

- $V_{1}=1$

Vejamos agora como determinar o segundo dígito de controle do exemplo:

1. Acrescente aos algarismos do CPF o dígito de controle $\left(V_{1}\right)$ e posicione os algarismos da base de cálculo, agora de 0 a 9 .

\begin{tabular}{|l|l|l|l|l|l|l|l|l|l|}
\hline 4 & 4 & 4 & 5 & 5 & 5 & 6 & 6 & 6 & 1 \\
\hline 0 & 1 & 2 & 3 & 4 & 5 & 6 & 7 & 8 & 9 \\
\hline
\end{tabular}

2. Multiplicando os algarismos correspondentes e somando todos os produtos obtidos, teremos:

- $S_{2}=0 \times 4+1 \times 4+2 \times 4+3 \times 5+4 \times 5+5 \times 5+6 \times 6+7 \times 6+8 \times 6+9 \times 1$

- $\mathrm{S}_{2}=207$

3. Dividindo o resultado da soma $\left(\mathrm{S}_{2}\right)$ por 11 , teremos:

- $207=11 \times 18+9$

4. Logo, o segundo dígito de controle será o algarismo 9 , ou seja,

- $V_{2}=9$

5. Portanto, o CPF completo é: $444.555 .666-19$

A seguir, será apresentado outro algoritmo, geralmente, utilizado para o cálculo dos dígitos de controle do CPF. Observe que esse algoritmo é similar ao anterior, porém utiliza outra base para o cálculo:

Cálculo do primeiro dígito de verificação $\left(\mathrm{V}_{1}\right)$ :

1. Multiplique cada um dos 9 primeiros dígitos $\left(A_{1} A_{2} A_{3} A_{4} A_{5} A_{6} A_{7} A_{8} R\right)$, sucessivamente, pela base de cálculo $\{10,9,8,7,6,5,4,3,2\}$.

2. Some os produtos obtidos.

3. Divida a soma obtida por 11. 
4. O primeiro dígito de verificação é o quanto falta para 11 no resto desta divisão, ou seja, é o valor que acrescentado à soma obtida a torne um múltiplo de 11. Se este complemento for maior ou igual a 10 , então toma-se o valor 0 , ou seja, $V_{1}=0$.

Cálculo do segundo dígito de controle $\left(\mathrm{V}_{2}\right)$ :

1. Acrescente o primeiro dígito de verificação encontrado e multiplique os 10 primeiros dígitos $\left(A_{1} A_{2} A_{3} A_{4} A_{5} A_{6} A_{7} A_{8} R V_{1}\right)$, nessa ordem, pela base de cálculo $\{11,10,9,8,7,6,5,4,3,2\}$.

2. Some os produtos obtidos.

3. Divida a soma obtida por 11.

4. O segundo dígito de verificação também será obtido da mesma maneira que $V_{1}$, ou seja, é a diferença entre 11 e o resto desta divisão.

Esse algoritmo também será aplicado para o CPF: 444.555.666, observe:

Cálculo do primeiro dígito verificador:

\begin{tabular}{|c|l|l|l|l|l|l|l|l|}
\hline 4 & 4 & 4 & 5 & 5 & 5 & 6 & 6 & 6 \\
\hline 10 & 9 & 8 & 7 & 6 & 5 & 4 & 3 & 2 \\
\hline
\end{tabular}

Efetuando os produtos correspondentes e somando, obteremos:

- $S_{1}^{\prime}=10 \times 4+9 \times 4+8 \times 4+7 \times 5+6 \times 5+5 \times 5+4 \times 6+3 \times 6+2 \times 6$

- $S^{\prime}{ }_{1}=252$

Dividindo o resultado da soma $\left(S^{\prime}{ }_{1}\right)$ por 11 , teremos:

- $252=11 \times 22+10$

Como o resto é 10 , o valor que falta para 11 é 1 .

- $V_{1}=11-10=1$

Então, o primeiro dígito verificador será o algarismo 1, portanto:

- $V_{1}=1$

Cálculo do segundo dígito verificador:

1. Acrescente aos algarismos do CPF o dígito de verificação $\left(V_{1}\right)$ e posicione os algarismos da base de cálculo, agora de 11 a 2.

\begin{tabular}{|l|l|l|l|l|l|l|l|l|l|}
\hline 4 & 4 & 4 & 5 & 5 & 5 & 6 & 6 & 6 & 1 \\
\hline
\end{tabular}




\begin{tabular}{|l|l|l|l|l|l|l|l|l|l|}
\hline 11 & 10 & 9 & 8 & 7 & 6 & 5 & 4 & 3 & 2 \\
\hline
\end{tabular}

- $S_{2}^{\prime}=11 \times 4+10 \times 4+9 \times 4+8 \times 5+7 \times 5+6 \times 5+5 \times 6+4 \times 6+3 \times 6+2 \times 1$

- $S_{2}^{\prime}=299$

2. Dividindo o resultado da soma $\left(\mathrm{S}_{2}{ }_{2}\right)$ por 11 , teremos:

- $299=11 \times 27+2$

- $V_{2}=11-2=9$

3. Logo, o segundo dígito de verificação será o algarismo 9, ou seja,

- $V_{2}=9$

4. Concluímos então, que o CPF completo é: 444.555.666-19

Observe que, embora os dois algoritmos utilizem bases diferentes para a multiplicação, resultam nos mesmos dígitos de verificação. Porque isso ocorre?

Considere o CPF com o formato: $A_{1} A_{2} A_{3} A_{4} A_{5} A_{6} A_{7} A_{8} R V_{1}$.

Vamos calcular o primeiro dígito de verificação. Inicialmente, utilizando o primeiro algoritmo, teremos:

$$
S_{1}=1 A_{1}+2 A_{2}+3 A_{3}+4 A_{4}+5 A_{5}+6 A_{6}+7 A_{7}+8 A_{8}+9 R
$$

Aplicando o segundo algoritmo, obtemos:

$$
S_{2}=10 A_{1}+9 A_{2}+8 A_{3}+7 A_{4}+6 A_{5}+5 A_{6}+4 A_{7}+3 A_{8}+2 R
$$

Somando as duas equações, obtemos:

$S_{1}+S_{2}=11 A_{1}+11 A_{2}+11 A_{3}+11 A_{4}+11 A_{5}+11 A_{6}+11 A_{7}+11 A_{8}+11 R$ $S_{1}+S_{2}=11\left(A_{1}+A_{2}+A_{3}+A_{4}+A_{5}+A_{6}+A_{7}+A_{8}+R\right)$

Logo $S_{1}+S_{2}$ é múltiplo de 11 .

Sejam:

$S_{1}=11 q_{1}+r_{1} \rightarrow$ com dígito verificador $V_{1}=r_{1} \mathrm{e}$

$S_{2}=11 q_{2}+r_{2} \rightarrow$ com dígito verificador $V_{2}=11-r_{2}$, sendo que, $0 \leq r_{1}, r_{2} \leq 10$ (2) Somando, obtemos:

$$
\begin{aligned}
& S_{1}+S_{2}=11 q_{1}+11 q_{2}+r_{1}+r_{2} \\
& S_{1}+S_{2}=11\left(q_{1}+q_{2}\right)+r_{1}+r_{2}
\end{aligned}
$$

Logo, $r_{1}+r_{2}$ é múltiplo de 11, pois por (1), temos que $S_{1}+S_{2}$, é múltiplo de 11 , e $0 \leq r_{1}+r_{2} \leq 20$, pois por (2) temos $0 \leq r_{1}, r_{2} \leq 10$.

Então,

$$
\left\{\begin{array}{ll}
r_{1}+r_{2}=0 & (3) \\
r_{1}+r_{2}=11 & \text { (4) }
\end{array}\right. \text { ou }
$$

(3) se $r_{1}+r_{2}=0$ então $r_{1}=0$ e $r_{2}=0$

(4) se $r_{1}+r_{2}=11$ então $r_{1}=11-r_{2}=V_{2}$ 


\subsubsection{Detecção de Erros}

Observe que, quando o primeiro dígito é 0 , pode haver um erro que não é detectado. Isso pode ocorrer quando o resto da divisão da soma dos produtos por 11 for igual a 10. Veja que, se o primeiro algarismo $\left(A_{1}\right)$ for trocado por $\left(A_{1}+1\right)$, a soma dos produtos aumentará em uma unidade, logo ela será múltiplo de 11. Sendo assim, também será atribuído o algarismo 0 ao digito de verificação.

Quando a soma dos produtos for um número múltiplo de 11, pode haver um erro que não é detectado. Observe que, se o primeiro algarismo $\left(A_{1}\right)$ for trocado por $\left(A_{1}-1\right)$, a soma dos produtos diminuirá em uma unidade, então ao ser dividida por 11 resultará em resto 10 , que também atribui o algarismo 0 ao digito de verificação.

\subsection{O CÓDIGO DE VERIFICAÇÃO DO ISBN}

O ISBN é um sistema que identifica numericamente os livros segundo o título, o autor, o país e a editora, individualizando-os inclusive por edição. O sistema foi desenvolvido a partir do sistema de numeração do livro introduzido no Reino Unido em 1967, por J. Whitaker \& Sons, e nos Estados Unidos em 1969, por R. R. Bowker, sendo oficializado como norma internacional em 1972. Ele é controlado pela Agência Internacional do ISBN, que orienta as agências nacionais e Ihes delega poderes. O sistema, atualmente, é utilizado em mais de 160 países. ${ }^{1}$

\footnotetext{
${ }^{1}$ A versão mais atualizada do Manual do Usuário ISBN será encontrada no website da International ISBN Agency:< http://www.isbn-international.org > último acesso em 12 nov 2015

ISBN 978-92-95055-08-7 @2011 by International ISBN Agency, London, UK Sexta Edição
} 
No Brasil, a Fundação Biblioteca Nacional representa a Agência Brasileira desde 1978 e é responsável pela atribuição do número de identificação aos livros editados no país.

Desde janeiro de 2007, o número de identificação do ISBN passou de dez para 13 algarismos sendo acrescentado a ele o prefixo 978 estabelecido pela GS1 (antiga EAN International e o Uniform Code Council). No futuro, quando necessário, serão utilizados outros prefixos. O objetivo dessa alteração foi aumentar a capacidade numérica do sistema tornando-o completamente compatível com o sistema do código de barras EAN13.

O uso correto do ISBN permite que diferentes formas de produto e edições de um livro, impressas ou digitais possam ser nitidamente distinguidas, garantindo assim que os clientes recebam a versão solicitada. Ele facilita, também, a compilação e atualização dos catálogos do comércio e das bases de dados bibliográficos como os catálogos de livros impressos. As informações sobre os livros disponíveis são facilmente encontradas, agilizando, assim, a comercialização. O número de identificação do ISBN é legivel por máquinas através do código de barras EAN de 13 algarismos.

O número de identificação do ISBN possui a seguinte estrutura:

$$
\text { ISBN } A_{1} A_{2} A_{3} \quad A_{4} A_{5} \quad A_{6} A_{7} A_{8} \quad A_{9} A_{10} A_{11} A_{12} \quad A_{13}
$$

Ele está dividido em 5 partes, sendo que os comprimentos das três do meio podem variar. As informações contidas no ISBN são:

- Prefixo: são os três primeiros algarismos. Os prefixos já disponibilizados pelo GS1 são o 978 e o 979 (indicam a indústria, neste caso, produção de livros).

- O Grupo de registro: é a segunda parte, que pode compreender de um a cinco algarismos. Ela identifica o país, a região demográfica ou a área linguística participante no sistema ISBN. São utilizados, por exemplo, identificadores com um algarismo: 0 ou 1 para países de língua inglesa, 2 para a língua francesa, 3 para a língua alemã, 4 para o Japão. Com dois ou mais algarismos, 85 para o do Brasil, 972 o de Portugal e com cinco algarismos temos 99939 para Macau.

- Editor: o ISBN nessa terceira parte identifica um editor em particular do grupo, ou uma edição no âmbito de um registro em particular.

- Edição 
- Dígito de verificação

Sendo que o dígito de controle, ou verificação, é determinado através de operações básicas realizadas com os próprios algarismos do ISBN, envolvendo conceitos de múltiplos e de divisibilidade.

A seguir será apresentado o algoritmo utilizado para o cálculo do dígito de verificação que era utilizado no ISBN-10.

a) Multiplique os nove primeiros algarismos $\left(a_{1} a_{2} a_{3} a_{4} a_{5} a_{6} a_{7} a_{8} a_{9}\right)$, nessa ordem, pela base de cálculo $\{10,9,8,7,6,5,4,3,2\}$.

b) Some os produtos obtidos.

c) Divida a soma obtida por 11 .

d) O dígito verificador é o número que deverá ser acrescentado à soma obtida para que ela seja múltiplo de 11 . No caso em que o resto for igual a 1 , o valor a ser acrescentado será 10 , neste caso, o dígito verificador utilizado será a letra " $X "$ ".

Vejamos um exemplo:

Consideremos o número de identificação ISBN 85-314-0458-4 do livro intitulado "Números Uma Introdução à Matemática". Vejamos o cálculo do dígito verificador que, como podemos observar, é igual a 4.

1. Posicionando os algarismos da base de cálculo abaixo dos do ISBN, teremos:

\begin{tabular}{|c|c|c|c|c|c|c|c|c|}
\hline 8 & 5 & 3 & 1 & 4 & 0 & 4 & 5 & 8 \\
\hline 10 & 9 & $\mathbf{8}$ & $\mathbf{7}$ & $\mathbf{6}$ & $\mathbf{5}$ & $\mathbf{4}$ & $\mathbf{3}$ & $\mathbf{2}$ \\
\hline
\end{tabular}

2. Efetuando as multiplicações correspondentes e somando os produtos obtidos, obteremos:

- $S_{1}=8 \times 10+5 \times 9+3 \times 8+1 \times 7+4 \times 6+0 \times 5+4 \times 4+5 \times 3+8 \times 2$

- $S_{1}=80+45+24+7+24+0+16+15+16$

- $S_{1}=227$

Dividindo o resultado da soma $\left(S_{1}\right)$ por 11 , teremos:

- $227=20 \times 11+7$ 
Logo, o dígito verificador é igual a 4, pois $(11-7=4)$

Desde que o número de identificação do ISBN passou de dez para 13 algarismos, tornando-se compatível com o sistema EAN-13, o algoritmo para a atribuição do dígito de verificação, também, passou a ser o mesmo. 


\title{
3 FUNDAMENTAÇÃO PARA ABORDAGEM PEDAGÓGICA
}

Nos documentos curriculares brasileiros, como os Parâmetros Curriculares Nacionais (PCN) para os terceiros e quartos ciclos do Ensino Fundamental, destacam-se discussões em Educação Matemática que acontecem no Brasil e no mundo apontando: "a necessidade de adequar o trabalho escolar a uma nova realidade, marcada pela crescente presença da Matemática em diversos campos da atividade humana" (BRASIL, 1998, p. 19).

Nesses ciclos os PCN abordam uma questão interessante que pode contribuir com o trabalho do professor.

\begin{abstract}
Outro aspecto importante que o professor precisa levar em conta consiste em canalizar para a aprendizagem toda a ebulição desse espírito questionador, que estimula os alunos a buscar explicações e finalidades para as coisas, discutindo questões relativas à utilidade da Matemática, como ela foi construída, como pode contribuir para a solução tanto de problemas do cotidiano como de problemas ligados à investigação científica. Desse modo, o aluno pode identificar os conhecimentos matemáticos como meios que o auxiliam a compreender e atuar no mundo. (BRASIL, 1998, p. 62-63).
\end{abstract}

Assim, esse período de disposição (questionador) pode ser aproveitado pelo professor durante a aula de Matemática como uma oportunidade de transformá-la em momentos estimulantes, que exijam estratégias para resolução de diversas situaçõesproblema. Por isso, aplicar questões focadas apenas em repetições de técnicas, a fim de verificar se os conteúdos foram fixados, não é o melhor caminho, uma vez que são desestimulantes aos alunos e não avaliam corretamente se o assunto foi ou não assimilado. É importante que o professor se certifique que o aluno perceba a inter-relação dos conhecimentos matemáticos para compreender o mundo e sua realidade.

Assim, no terceiro ciclo eles devem ser estimulados a construir e analisar diferentes processos de resolução de situações-problema e compará-los. Verificamos, também, a valorização dos processos e a socialização dos resultados na resolução de problemas. 
Resolver um problema pressupõe que o aluno: elabore um ou vários procedimentos de resolução (como realizar simulações, fazer tentativas, formular hipóteses); compare seus resultados com os de outros alunos; valide seus procedimentos (BRASIL, 1998, p. 40).

Na visão de Schoenfeld² (1996 apud LAMONATO; PASSOS, 2011, p. 60), um problema pode ser avaliado sob quatros aspectos:

(a) Deve ser acessível e facilmente compreendido, com vocabulário acessível à maioria dos alunos;

(b) Deve poder ser resolvido de maneira diversa e oferecer múltiplas soluções, valorizando as conexões, em vez das respostas;

(c) Deve servir, assim com suas soluções, para a introdução de ideias importantes e

(d) Deve, se possível, favorecer honestas e boas explorações matemáticas.

Também Ponte, Brocardo e Oliveira (2005) analisam os objetivos gerais dos Parâmetros Curriculares Nacionais para o ensino fundamental e apontam à significativa importância dada à realização de atividades de investigação e pesquisa no ensino e na aprendizagem da Matemática, em estreita associação com a resolução de problemas. Esses autores observam que entre os objetivos gerais surge o desenvolvimento do "espírito de investigação" e "da capacidade para resolver problemas", e com igual importância de os alunos serem capazes de "argumentar sobre suas conjecturas".

Diante das considerações acima, vimos que os Parâmetros Curriculares Nacionais indicam diversas necessidades e objetivos acerca do ensino da Matemática no Brasil, sobretudo, aquelas ligadas ao reconhecimento da Matemática como ciência presente no desenvolvimento da atividade humana. Desse modo, explorá-la a partir dos problemas vividos no cotidiano e, também, abordar o desempenho do papel ativo do aluno na construção do seu conhecimento. Para tanto, este capítulo terá como foco duas metodologias que contribuem para esses fins. São elas: a Resolução de Problemas e a Investigação Matemática.

${ }^{2}$ SCHOENFELD, A. H. Porquê toda essa agitação acerca da resolução de problemas? In: ABRANTES, P.; LEAL, L. C.; PONTE, J. P. da. Investigar para aprender Matemática (textos selecionados). Lisboa: Associação dos Professores de Matemática, 1996. p. 61-71. 


\subsection{A RESOLUÇÃO DE PROBLEMAS}

Ao longo da década de 1980, muitas pesquisas foram desenvolvidas, em âmbito internacional, a respeito da Resolução de Problemas, com enfoque e abordagens distintas. Segundo Onuchic e Allevato (2004), nesse período, foram elaborados muitos recursos, visando ao trabalho em sala de aula, tais como: listas de problemas, sugestões de atividades, listas de estratégias e também orientações com o intuito de avaliar o desempenho em resolução de problemas.

Segundo Onuchic (2011), com esse material, muitos professores fizeram da Resolução de Problemas o ponto central de seus trabalhos, porém, dificuldades foram encontradas por parte de alguns professores em "ensinar", bem como de alguns alunos em "aprender". Esses obstáculos tornaram-se objetos de estudo de reconceitualização por educadores e pesquisadores na Educação Matemática - embora essas pesquisas ainda não estivessem totalmente homogêneas entre os autores (informação verbal) ${ }^{3}$.

Assim, ao final da década de 1980, conforme descrevem Allevato e Onuchic (2009), os pesquisadores começaram a convergir seus questionamentos quanto aos efeitos da Resolução de Problemas - no sentido de estratégias e modelos - e, dessa forma, discutirem as perspectivas didático-pedagógicas sobre o tema. "Ela passa a ser pensada como uma metodologia de ensino, como um ponto de partida e um meio de se ensinar matemática" (ALLEVATO e ONUCHIC, 2009, p.5).

Desde então, muitas pesquisas foram desenvolvidas, em diversos países, na área de Educação Matemática tendo como foco a Resolução de Problemas.

No Brasil, novas discussões desta linha de ensino e pesquisa foram desencadeadas, segundo Allevato (2005), desde a tradução, em 1997, da obra organizada por Krulik e Reys, Problem Solving in School Mathematics (1980). Esse livro traz artigos de especialistas, sendo, o primeiro, a reprodução de um texto de George Polya, de 1949.

\footnotetext{
${ }^{3}$ Informação fornecida por Onuchic no II Seminário em Resolução de Problemas, em 2011. Disponivel em:< https://www.youtube.com/watch?v=FAki2 FpoGw. $>$ último acesso em: 18 out. 2014.
} 


\begin{abstract}
Ressalte-se, ainda, que ao longo de todo o livro se pode perceber a forte influência que suas ideias, apresentadas no livro How to solve it (1945), exerciam sobre as orientações para a implementação da resolução de problemas em sala de aula. O livro de Polya (1945) tornou-se referência nesse tema e possui uma tradução em português, relativamente recente, intitulada A Arte de Resolver Problemas (1994) (ALLEVATO, 2005, p. 49).
\end{abstract}

Ainda no Brasil, percebemos a influência dessas ideias na formulação de documentos oficiais. Nos Parâmetros Curriculares Nacionais, recomenda-se a Resolução de Problemas como metodologia de ensino desde as séries iniciais "como eixo organizador do processo de ensino e aprendizagem de Matemática" (BRASIL, 1998, p. 40).

\title{
3.1.1 A Metodologia de Resolução de Problemas
}

Na literatura de Educação Matemática, podemos encontrar diversos autores que, no estudo da Resolução de Problemas, visam aprofundar a compreensão, as implicações e finalidades dessa Metodologia. Nesta seção, focaremos na seguinte estrutura: $O$ problema na construção do conhecimento matemático e A Resolução de Problemas na Educação Matemática.

\subsubsection{A Resolução de Problemas na Atividade Matemática}

Sabemos que, muitas vezes, a Matemática é vista como uma ciência exata, estática e acabada. Entretanto, ao voltarmos o olhar para a história da construção do conhecimento matemático, notamos que a Matemática é dinâmica, uma vez que muitos dos resultados obtidos foram descobertos de maneira indutiva e experimental. Diversas vezes, foi a busca pela solução de um problema específico que possibilitou a descoberta desses novos resultados. Contudo, não se pode negar que a resolução de tais problemas matemáticos exige, também, algum domínio anterior da linguagem matemática, o 
conhecimento de fatos e a compreensão de algumas estruturas que sustentam a Matemática como área de conhecimento.

Para Allevato (2005), é evidente que a busca pela resolução de um problema nem sempre é fácil; em geral, é longa, árdua e promovida por pessoas extremamente determinadas. Por exemplo, alguns problemas foram investigados durante séculos, construindo, assim, resultados determinantes na trajetória da construção do conhecimento. Dessa forma, tal construção é dada por um ciclo, cuja mola propulsora é o problema: ele gera novos conhecimentos, dos quais geram novas teorias, que geram novas pesquisas e, por fim, novos problemas.

\subsubsection{Um problema matemático}

O termo "problema" é muito usual no cotidiano de pessoas que trabalham com Matemática, no entanto, ele pode ser usado em diversos sentidos. Geralmente, o único objetivo é obter a resposta e, uma vez obtida, o problema está solucionado; como se houvesse apenas um caminho para chegar à solução.

Por outro lado, alguns autores convergem para uma formulação mais consistente e ampla. De maneira ampla, "temos um problema sempre que procuramos os meios para atingir um objetivo. Quando temos um desejo que não podemos satisfazer imediatamente, pensamos os meios de satisfazê-lo e, assim, se põe um problema" (POLYA, 1985, p. 13).

Ainda nessa linha, Dante (2009) revela que um problema pode ser definido como qualquer situação na qual o indivíduo precisa pensar para solucionar. Ele ainda estabelece que a solução de um problema matemático exige a maneira matemática de pensar e conhecimentos matemáticos.

Este entendimento é próximo do que afirmam Onuchic e Allevato (2004, p. 221):

Problema é tudo aquilo que não sabemos fazer, mas que estamos interessados em saber. [...] problema é definido como qualquer tarefa ou atividade para a qual os estudantes não têm método ou regra, prescritas 
ou memorizadas, nem a percepção de que haja um método específico para chegar à solução correta.

Por outro lado, é de extrema importância compreender o problema não apenas no seu sentido amplo, mas também nas suas respectivas classificações. Comumente, os autores referem-se a duas delas: problemas fechados e problemas abertos. Para Shimada $^{4}$ (1997 apud ALLEVATO, 2005), o primeiro tipo, fechado, é aquele tradicionalmente utilizado nas abordagens de ensino, em que o problema tem apenas uma resposta correta e predeterminada. Por outro lado, o segundo tipo, aberto, abrange diversas respostas corretas ou mesmo vários caminhos metodológicos para obter a resposta.

Outra contribuição relevante, acerca desta última abordagem, é a de Van de Walle (2009). Ele acredita que os problemas abertos devem ser utilizados quando a finalidade for a de realizar explorações matemáticas. Para tanto, adota os critérios de Hashimoto e Becker $^{5}$ (1999 apud VAN DE WALLE, 2009), os quais o caracterizam como: o processo é aberto (são explorados múltiplos caminhos para a solução), o final é aberto (há múltiplas respostas corretas a serem descobertas) e, por fim, a formulação de novos problemas é aberta (os alunos exploram novos problemas relacionados ao problema dado).

\subsubsection{A Resolução de problemas na Educação Matemática}

Diversas justificativas têm sido elaboradas sobre o porquê do uso da Resolução de Problemas no ensino de Matemática. Dentre elas, destacamos a de Polya (1985) que observou ser imprescindível reconhecer como ponto de partida a prática de resolver problemas como intrínseca à natureza de qualquer atividade humana, além de considerála fundamental para o desenvolvimento da inteligência - que é, também, um dos principais objetivos da Educação.

${ }^{4}$ SHIMADA, S. The Significance of an Open-Ended Approach. In: BECKER, J.P.; SHIMADA, S. (Ed.). The Open-Ended Approach: A New Proposal for Teaching Mathematics. Reston: NCTM, 1997. p. 1-9. 
Nessa mesma abordagem, Dante (2009) ressalta alguns outros aspectos da resolução de problemas, dentre eles: levar o aluno a pensar produtivamente e desenvolver o raciocínio; fornecer estratégias para resolver problemas; dar-lhe oportunidade de se envolver com aplicações da Matemática, enfrentar situações novas e de adquirir uma boa base matemática.

Ele ainda apresenta uma classificação para os diferentes tipos de problemas, exemplificando-os, como vemos na Tabela 5 , a seguir.

\begin{tabular}{|c|c|}
\hline Tipo & Objetivo \\
\hline Exercícios de reconhecimento & $\begin{array}{l}\text { Levar o aluno a identificar ou lembrar um conceito, um } \\
\text { fato específico, uma definição, uma propriedade. } \\
\text { Ex: Dados os números } 2,5,10,103,156 \text { e } 207 \text {, quais } \\
\text { são pares }\end{array}$ \\
\hline Exercícios de algoritmos & $\begin{array}{l}\text { Treinar a habilidade de execução de um algoritmo e } \\
\text { reforçar conhecimentos anteriores. } \\
\text { Ex: Calcule o valor de }[(3 \times 4)+2] \div 7\end{array}$ \\
\hline $\begin{array}{l}\text { Problemas-padrão } \\
\text { - Simples } \\
\text { - Compostos }\end{array}$ & $\begin{array}{l}\text { Fixar fatos básicos e algoritmos vinculando seu } \\
\text { emprego a situaçöes do dia-a-dia em que é preciso } \\
\text { transformar linguagem usual em linguagem } \\
\text { matemática. } \\
\text { Ex1: Numa classe há } 17 \text { meninos e } 22 \text { meninas. } \\
\text { Quantos alunos há na classe } \\
\text { Ex2: Luís tem } 7 \text { anos a mais que o triplo da idade de } \\
\text { Felipe. Os dois juntos têm } 55 \text { anos. Qual é a idade de } \\
\text { cada um? }\end{array}$ \\
\hline $\begin{array}{l}\text { Problemas-processo ou heurísticos (A esses } \\
\text { ele chama, simplesmente, problemas) }\end{array}$ & $\begin{array}{l}\text { Levar o aluno a pensar, arquitetar um plano de ação e } \\
\text { elaborar uma estratégia para chegar à solução. Tais } \\
\text { problemas não podem ser diretamente traduzidos para } \\
\text { a linguagem matemática ou resolvidos por aplicação } \\
\text { automática de um algoritmo. Iniciam o aluno no } \\
\text { desenvolvimento de estratégias e procedimentos. } \\
\text { Ex: Numa reunião de equipe há } 6 \text { alunos. Se cada um } \\
\text { trocar um aperto de mão com todos os outros, quantos } \\
\text { apertos de mão teremos ao todo? }\end{array}$ \\
\hline
\end{tabular}




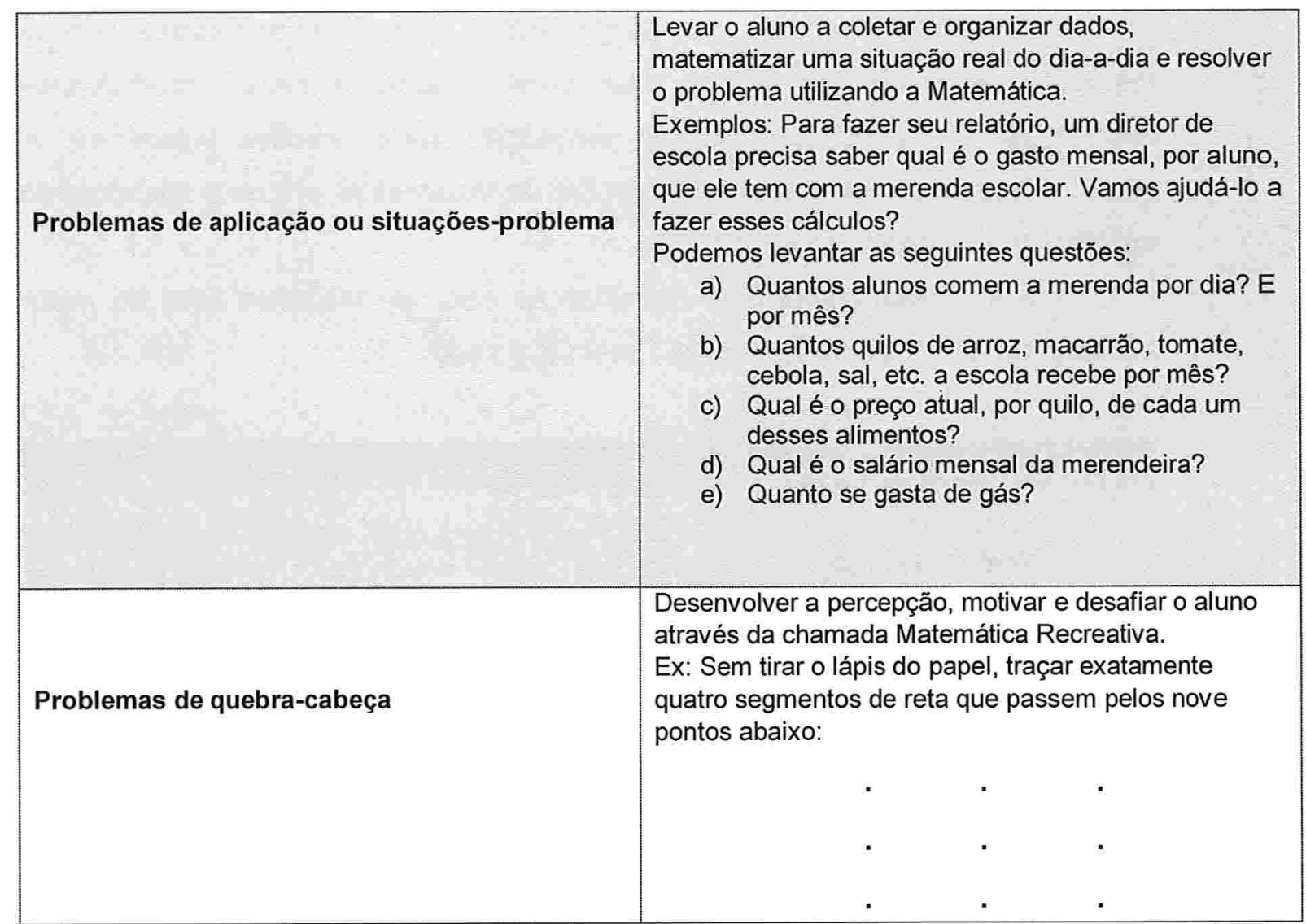

Tabela 5: Classificação para os diferentes tipos de problemas Dados extraídos de Dante (2009)

Mendonça (1999) considera importante elucidar as interpretações dadas à resolução de problema, no Brasil e, talvez, no mundo: um objetivo, em que se ensina a Matemática para resolver problemas; um processo, em que a ênfase está no desempenho/transformação e nas estratégias usadas pelos alunos; ponto de partida, em que o problema é um recurso pedagógico considerado como um elemento que desencadeia um processo de construção do conhecimento (grifos da autora, p. 16).

A autora considera que a interpretação "ponto de partida" contraria a interpretação "objetivo" e abrange, ao menos parcialmente, a de "ponto de partida". Nesse último caso, os problemas são propostos a fim de conduzir à formação dos conceitos antes de sua apresentação em linguagem matemática formal, assim, as ideias e sugestões dos alunos têm um papel fundamental na aprendizagem. 
Para auxiliar o leitor a compreender melhor tais interpretações, a autora toma como exemplo o famoso problema das "galinhas e porcos", exemplificado abaixo, contextualizando em cada uma delas.

Em um sítio há galinhas e porcos. No total, há 97 cabeças e 264 pés. Quantas são as galinhas e quantos são os porcos?

Para um professor/a que aplica a Resolução de Problemas como um:

a. Objetivo: esse problema seria apresentado após a teoria sobre sistemas lineares, visando controlar a aprendizagem desse conteúdo e treinar técnicas de solução de sistema de equação;

b. Processo: esse problema seria um instrumento de reflexão do processo pedagógico de encaminhar o aluno a descobrir por si mesmo como solucionar problemas que apresentam dados que envolvam duas grandezas interrelacionadas - o aluno pode, por exemplo, utilizar a estratégia de solução a tentativa e erro e, então, o professor poderia trabalhar no sentido da sistematização e melhoria de tais procedimentos.

c. Ponto de Partida: esse problema pode ser um convite à exploração e discussão para iniciar um processo de aprendizagem, de modo a organizar e construir o conhecimento do aluno, em diferentes níveis de complexidade, sobre equações algébricas correlacionadas.

Vale ressaltar, também, as observações de Onuchic (1999) que, ao analisar os objetivos da Resolução de Problemas, sob a ótica de Schroeder e Lester (1989), salienta que essa função é, essencialmente, determinada pela abordagem a qual configura a atividade de ensino do professor: ensinar sobre resolução de problemas, para a resolução de problemas ou através da resolução de problemas.

A seguir será apresentada uma breve análise das características de cada uma dessas concepções.

a) Ensinar sobre resolução de problema: 
O livro de Polya: How to Solve it - cuja tradução foi intitulada como "A arte de resolver problemas" - tornou-se uma referência nesse tema e pode ser considerado, talvez, o mais importante exemplo entre os trabalhos com teor essencialmente voltado a ensinar sobre resolução de problemas. Ele, ao colocar seu conhecido roteiro com orientações sobre como resolver um problema, classifica-o nas seguintes etapas: compreender o problema, estabelecer um plano, executar o plano e fazer um retrospecto para examinar a solução obtida.

Essa obra inspirou, e ainda inspira, muitos pesquisadores no desenvolvimento dessa concepção, adotando-a como base fundamental de suas abordagens. Dante (2009), corrobora essa concepção, ao argumentar que é necessária a adoção de estratégias - por exemplo, tentativa e erro organizados, procurar padrões e generalizações, resolver primeiro um problema mais simples, reduzir à unidade e fazer um caminho inverso - cuja finalidade seja obter uma orientação específica de como se resolve um problema.

Segundo ele:

Ensinar a resolver problemas é uma tarefa mais difícil do que ensinar conceitos, habilidades e algoritmos matemáticos. Não é um mecanismo direto de ensino, mas uma variedade de processos que precisam ser cuidadosamente desenvolvidos pelo aluno com o apoio e incentivo do professor (DANTE, 2009, p. 36).

Assim, o autor esclarece que a habilidade de resolver problemas não se desenvolverá como consequência natural da aprendizagem dos conteúdos matemáticos - embora muitos professores, ainda, acreditem que o aluno ao dominar tais conteúdos, terá habilidade em resolver problemas.

Visivelmente, Dante não desconsidera a importância de se ensinar os conceitos, habilidades e algoritmos matemáticos, ao contrário, ele reforça sua relevância, mas, também, nos alerta sobre a importância de o professor ensinar a Resolução de Problemas como um novo conteúdo aos alunos, tais como os demais.

Ainda em conformidade com essa linha, Thompson (1989 apud Allevato, 2005) reforça a ideia de que não se pode esperar progresso em resolução de problemas, enquanto não se ensinar a resolvê-los. Sugere, portanto, que a resolução de problemas deva ser mais um conteúdo a ser ensinado. 


\section{b) Ensinar para resolução de Problema}

Ainda na obra de Thompsom (1989 apud Allevato, 2005), pode-se observar, também, sua visão sobre essa concepção, de ensinar para a resolução de problemas. Para ela, além de o professor sugerir problemas aos alunos, deve ajudá-los a relacionar os recursos matemáticos que conhecem com os métodos de resolução.

Dessa maneira, o professor procura ter em foco a ideia de como o conteúdo matemático que está sendo ensinado pode ser aplicado na resolução de problemas. Assim, o aluno é estimulado a desenvolver sua habilidade de transferir aquilo que aprendeu num contexto para problemas em outros contextos, isto é, o professor ensina para a resolução de problemas.

Santos (2002), acerca dessa abordagem, constata que frequentemente o professor apresenta o novo conteúdo, mostrando em seguida algumas aplicações através de exemplos. Segue-se, então, uma lista de exercícios na qual o aluno deverá aplicar o novo conteúdo; são os conhecidos exercícios de fixação. Lima (2000), inclusive, explica que tais aplicações, isto é, o emprego das noções e teorias da Matemática, possibilita ao aluno obter resultados, elaborar conclusões ou previsões em problemas, desde os mais simples presentes no cotidiano, até questões que envolvem outras áreas científicas.

Para ele "[...] as aplicações constituem a principal razão pela qual o ensino da matemática é tão difundido e necessário [...]" (p. 2) e, por isso, considera que a resolução de problemas deva ser uma das aplicações do conteúdo matemático. Lima ressalta, também, que "encontrar aplicações significativas para a matéria que está expondo é um desafio e deveria ser uma preocupação constante do professor" (p. 5).

Allevato (2005), afirma que esta forma de considerar a resolução de problemas, ajuda a tornar o ensino da Matemática mais interessante e dotado de sentido para os alunos - embora não deixe de ressaltar o cuidado para não limitar a concepção da Matemática como algo puramente utilitário.

c) Ensinar através da resolução de problemas

Essa concepção se baseia num problema inicial visando à construção de conceitos e ao ensino de diversos conteúdos, incluindo até procedimentos. Assim, o aprendizado pode ser visto: 
[...] como um movimento do concreto (um problema do mundo real que serve como exemplo do conceito ou da técnica operatória) para o abstrato (uma representação simbólica de uma classe de problemas e técnicas para operar com estes símbolos) (ONUCHIC; ALLEVATO, 2012, p. 242).

Segundo Onuchic, Allevato, (2012) o ensino de Matemática através da Resolução de Problemas concorda com as recomendações dos PCN, uma vez que:

- Habilidades e conceitos matemáticos são aprendidos no contexto da Resolução de Problemas,

- O desenvolvimento de processos de pensamentos de nível superior deve ser estimulado através de experiências em resolução de problemas e

- O ensino de matemática deve ocorrer por investigação orientada em um ambiente de resolução de problemas.

Com o intuito de aprimorar essa metodologia no ambiente da sala de aula, Allevato e Onuchic (2009) propõem etapas com as quais os professores podem direcionar tais atividades na prática com seus alunos. São elas: preparação do problema, leitura individual, leitura em conjunto, resolução do problema, observar e incentivar, registros das soluções na lousa, plenária, busca do consenso e formalização dos conteúdos. Cada etapa será detalhada na Tabela 6

\begin{tabular}{|l|l|}
\hline \multicolumn{2}{|c|}{ Estrutura } \\
\hline Preparação do problema & $\begin{array}{l}\text { Selecionar um problema "gerador" visando à } \\
\text { construção de um novo conceito, princípio ou } \\
\text { procedimento. }\end{array}$ \\
\hline Leitura individual & $\begin{array}{l}\text { Entregar uma cópia do problema para cada aluno } \\
\text { e solicitar que seja feita sua leitura. }\end{array}$ \\
\hline Leitura em conjunto & $\begin{array}{l}\text { Formar grupos e solicitar nova leitura do problema, } \\
\text { agora nos grupos. } \\
\text { o professor pode auxiliar na leitura, caso haja } \\
\text { dificuldade. }\end{array}$ \\
\hline Resolução do problema & $\begin{array}{l}\text { Em grupo, os alunos buscam resolver o problema } \\
\text { num trabalho cooperativo e colaborativo. }\end{array}$ \\
\hline
\end{tabular}




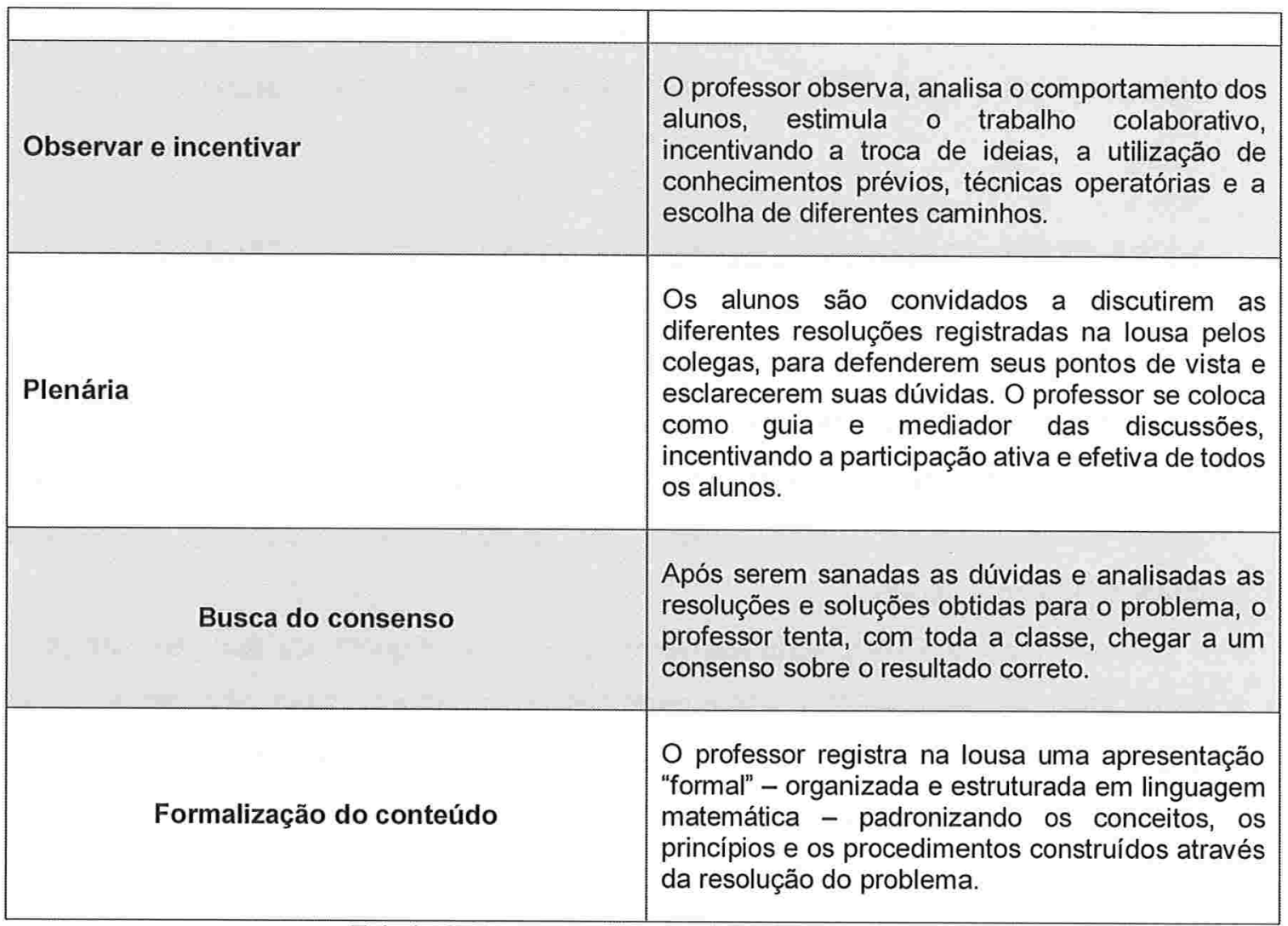

Tabela 6: Etapas para a resolução de problemas

Fonte: Alevatto e Onuchic (2009)

Van de Walle (2009), em seu trabalho, cujo público alvo eram os professores, não nega a dificuldade de se ensinar através da resolução de problemas, porém, apresenta algumas razões que justificam sua dedicação e empenho. Para ele, a Resolução de Problemas:

- Desenvolve nos estudantes a confiança e a autoestima de que eles são capazes de fazer matemática e de que ela faz sentido.

- Fornece dados de avaliação ao professor, dos quais permitem tomar decisões sobre o ensino e ajudar os estudantes a ter sucesso com a aprendizagem;

- Possibilita um ponto de partida para um grande número de alunos, pois possuem múltiplos caminhos para chegar à solução;

- Desenvolve o "potencial matemático"; 
Ressalta, também, que os alunos ficam motivados com o desenvolvimento de sua capacidade de compreensão que experimentam através do seu próprio raciocínio.

\subsection{DA RESOLUÇÃO DE PROBLEMAS À INVESTIGAÇÃO MATEMÁTICA}

No começo deste capítulo, vimos que a Resolução de Problemas tem sido, desde o início da década de 80 , uma abordagem na Educação Matemática. Sua contribuição foi sendo enriquecida, progressivamente, no sentido de desenvolver o pensamento matemático nos alunos.

Além disso, vimos algumas considerações a respeito do que seja um problema numa visão ampla, cujo foco era a exploração do contexto para além do que surge no enunciado, valorizando-se, então, todo o conjunto de processos característicos da resolução de problemas, tais como: formular, testar, argumentar e formalizar os resultados.

Na resolução de um problema para o qual não temos um caminho para nos guiar, iniciamos um processo de investigação matemática.

\footnotetext{
Uma investigação é uma viagem até o desconhecido. Tal ideia pode ser melhor entendida pela seguinte frase de Susan Pirie: 'o importante é explorar um aspecto da Matemática em todas as direções. O objetivo é a viagem e não o destino' (1987, p. 2). (FONSECA; BRUNHEIRA; PONTE, 1999, p. 2)
}

Assim, para Fonseca, Brunheira e Ponte (1999), se na resolução de problemas o objetivo é encontrar um caminho que alcance um ponto não instantaneamente atingivel - isto é, um processo convergente -, a investigação matemática, por outro lado, tem como objetivo explorar todos os caminhos que surgem como interessantes a partir de uma dada situação, ou seja, trata-se de um processo divergente. Nele, sabe-se qual é o ponto de partida, mas não se sabe qual será o ponto de chegada. 


\title{
3.3 METODOLOGIA: INVESTIGAÇÕES MATEMÁTICAS
}

A palavra investigar vem do latim investigare ${ }^{6}$, que significa pesquisar, indagar, seguir os vestígios de, investigar as causas de um fato, examinar com atenção.

A metodologia da Investigação Matemática vem sendo objeto de estudo de grande interesse por parte dos pesquisadores e professores que lecionam na área de Matemática, hoje, no Brasil e no mundo. Conforme mostram Lamonato e Passos (2011), ela é entendida como um meio pelo qual pode ocorrer a aprendizagem dessa ciência em um processo que visa a promover ao aluno o desenvolvimento da sua capacidade de pesquisar, buscar resposta, formular hipóteses e ser crítico no contexto do conhecimento matemático produzido.

\begin{abstract}
Em contextos de ensino e aprendizagem, investigar não significa necessariamente lidar com problemas muito sofisticados na fronteira do conhecimento. Significa tão-só, que reformulamos questões que nos interessam, para as quais não temos resposta pronta, e procuramos essa resposta de modo tanto quanto possível fundamentado e rigoroso. Desse modo, investigar não representa obrigatoriamente trabalhar em problemas muito difíceis. Significa, pelo contrário, trabalhar com questões que nos interpelam e que se apresentam no início de modo confuso, mas que procuramos clarificar e estudar de modo organizado (PONTE; BROCARDO; OLIVEIRA, 2005, p. 9).
\end{abstract}

Como dito na citação acima, trabalhar por meio da investigação matemática pode parecer, a princípio, um tanto confuso. Isso ocorre, pois se trata de questões abertas, isto é, a questão não é bem definida no início, cabendo a quem está investigando defini-la. Sendo, assim, tanto os pontos de partida como os pontos de chegada podem não ser, necessariamente, os mesmos. Devido à sua abertura, Abrantes, Leal e Ponte (1996 apud Lamonato; Passos, 2011) explicam que as atividades investigativas possibilitam a experiência do aluno com formulações de questões, conjecturas, testes, argumentação e discussão de ideias - aspectos centrais em uma nova maneira de ensino da Matemática.

\footnotetext{
${ }^{6}$ Dicionário Aurélio, $3^{\mathrm{a}}$ ed., 2004, p.1127.
} 
Sendo assim, é importante ressaltar, conforme colocam Ponte, Brocardo e Oliveira (2005), que a investigação matemática pode ser desenvolvida por meio de um ou mais problemas. Ao buscarmos a solução de um problema, podemos fazer outras descobertas, que em alguns casos, podem ser tão ou mais importante que a própria resposta que pode, por vezes, nem ser obtida. "Como cita o matemático inglês Andrew Wiles, 'é bom trabalhar em qualquer problema contanto que ele dê origem a Matemática interessante durante o caminho, mesmo se não o resolvemos no final'". (PONTE; BROCARDO; OLIVEIRA, 2005, p.17).

Durante a prática da Investigação, envolve-se uma alta variedade de processos, cujo grau de complexidade e até de imprevisibilidade podem oscilar, exigindo, portanto, uma preparação bastante cuidadosa do professor, que vai além da tarefa que propõe aos alunos. O professor deve pensar em intervenções que os levem a perceber o que eles próprios já produziram e examinar novas possibilidades. Além disso, sua atitude no papel de educador deve apresentar, também, um "caráter investigativo, e uma reflexão sobre os objetivos que se pretendem atingir com a realização das atividades de investigação" (FONSECA; BRUNHEIRA; PONTE, 1999, p. 3).

Por isso, segundo Ponte, Brocado e Oliveira (2005), o professor deve dar autonomia ao aluno para não comprometer a sua autoria de investigação e, simultaneamente, deve garantir que "o trabalho dos alunos vá fluindo e seja significativo do ponto de vista da disciplina Matemática" (PONTE; BROCARDO; OLIVEIRA, 2005, p. 47). Dessa forma, ele "continua a ser um elemento chave, mesmo nessas aulas, cabendo-lhe ajudar o aluno a compreender o que significa investigar e aprender a fazêIo" (PONTE; BROCARDO; OLIVEIRA, 2005, p. 26).

Para Ponte, Brocardo e Oliveira (2005), a realização de uma atividade de investigação, em aula de matemática, pode ser dividida em três fases fundamentais, conforme ilustra a Tabela 7 abaixo.

Os autores consideram que a fase final deve permitir a sistematização das principais ideias e a reflexão sobre as atividades, salientando, para os alunos, a importância de se justificar suas conjecturas. 
MOMENTOS

\begin{tabular}{|c|l|}
\hline \multicolumn{2}{|c|}{ MOMENTOS } \\
\hline Introdução da tarefa & $\begin{array}{l}\text { O professor faz a proposta à turma, oralmente ou } \\
\text { por escrito. }\end{array}$ \\
\hline Realização da investigação & $\begin{array}{l}\text { Individualmente, em duplas, pequenos grupos ou } \\
\text { com toda a turma. }\end{array}$ \\
\hline Discussão dos resultados & $\begin{array}{l}\text { Os alunos relatam aos colegas o trabalho realizado } \\
\text { e, finalmente, a discussão é feita em grande grupo. }\end{array}$ \\
\hline
\end{tabular}

Tabela 7: Etapas das atividades de investigação

Dados extraídos de Ponte, Brocardo e Oliveira (2005)

Ao realizarmos o estudo dessas duas metodologias, pudemos perceber que algumas perspectivas de se entender a Resolução de Problemas, se aproximam muito da essência da Investigação Matemática. Isso pode ser observado, por exemplo, quando a primeira é entendida como um "ponto de partida" (Mendonça,1999, p.16), para "ensinar a Matemática através da Resolução de Problemas" (ALLEVATO; ONUCHIC, 2012). Temos que o problema é um convite à investigação, à exploração e à discussão, ele é tido como desencadeador do conhecimento matemático. 


\section{A SEQUÊNCIA DIDÁTICA}

Um dos objetivos das atividades é despertar o interesse do aluno ao conhecer a aplicação de conteúdos matemáticos como divisibilidade de números naturais, múltiplos, números primos em código numéricos de identificação.

Segundo os Parâmetros Curriculares Nacionais, os conceitos de:

[...] múltiplo e divisor de um número natural ou o conceito de número primo podem ser abordados neste ciclo [...]. Além disso, é importante que tal trabalho não se resuma à apresentação de diferentes técnicas ou de dispositivos práticos que permitem ao aluno encontrar, mecanicamente, o mínimo múltiplo comum e máximo divisor comum sem compreender as situações-problema que esses conceitos permitem resolver (Brasil, 1998).

Para isso, optou-se por desenvolver atividades que possibilitem ao aluno, compreender as ideias matemáticas que envolvem a detecção de eventuais erros de digitação de código de barras e CPF.

Para poder explicar quais informações estão contidas nos códigos de barras, como são organizadas e, principalmente, possibilitar ao aluno compreender como funciona o processo de detecção de erros de digitação, foram desenvolvidas seis atividades. Os objetivos dessas atividades são:

1. Elaborar um código de identificação a partir de um problema proposto.

2. Atribuir dígitos de verificação para o código de identificação elaborado visando à detecção de um único erro de digitação.

3. Construir um algoritmo para gerar um único dígito verificador. A construção do algoritmo, com auxilio e sugestões do professor, leva a utilização de múltiplos de um número base. Nesta etapa, o aluno deve perceber que a escolha do número base é influenciada pela quantidade de restos distintos possíveis, ao se dividir por este número.

4. Explicar o algoritmo utilizado em código de barras para a detecção de erros e aplicá-lo ao código elaborado.

5. Perceber que a utilização de um número primo, em determinados algoritmos, pode proporcionar maior detecção de erros. Como mostraremos adiante, em alguns 
casos, essa percepção se deu como um insight, como uma verdadeira descoberta por parte de alguns alunos.

6. Conhecer o código de barras EAN-13.

Além de código de barras, foi elaborada uma atividade sobre outro código numérico de identificação: o CPF. Essa atividade tem como objetivo:

- Explicar como o CPF é formado e que operações matemáticas fazem com que eventuais erros de digitação possam ser detectados.

\section{Atividade 1}

\section{Etapa 1}

O tempo previsto: uma aula de 50 minutos.

Organização da turma: em equipes, organizadas pelos próprios alunos com, no máximo, quatro integrantes.

Objetivos:

- Reconhecer os números como possíveis codificadores.

- Associar um número a uma informação.

- Criar um código de identificação.

Orientações:

Antes de se iniciar a atividade, esclarecer aos alunos que:

- Não há uma única resposta.

- A resolução dessa atividade não exige a aplicação de "fórmulas" e que os conteúdos vistos até então são suficientes para a resolução.

- As ideias devem ser discutidas apenas entre os integrantes de cada equipe e que tentem resolver sem o auxílio do professor. Cada equipe deve apresentar uma sugestão, conforme proposto pelo problema.

Abaixo, apresentamos a atividade a ser proposta aos alunos, seguida de suas análises a priori e de considerações sobre o que é esperado em relação à conclusão da atividade. 


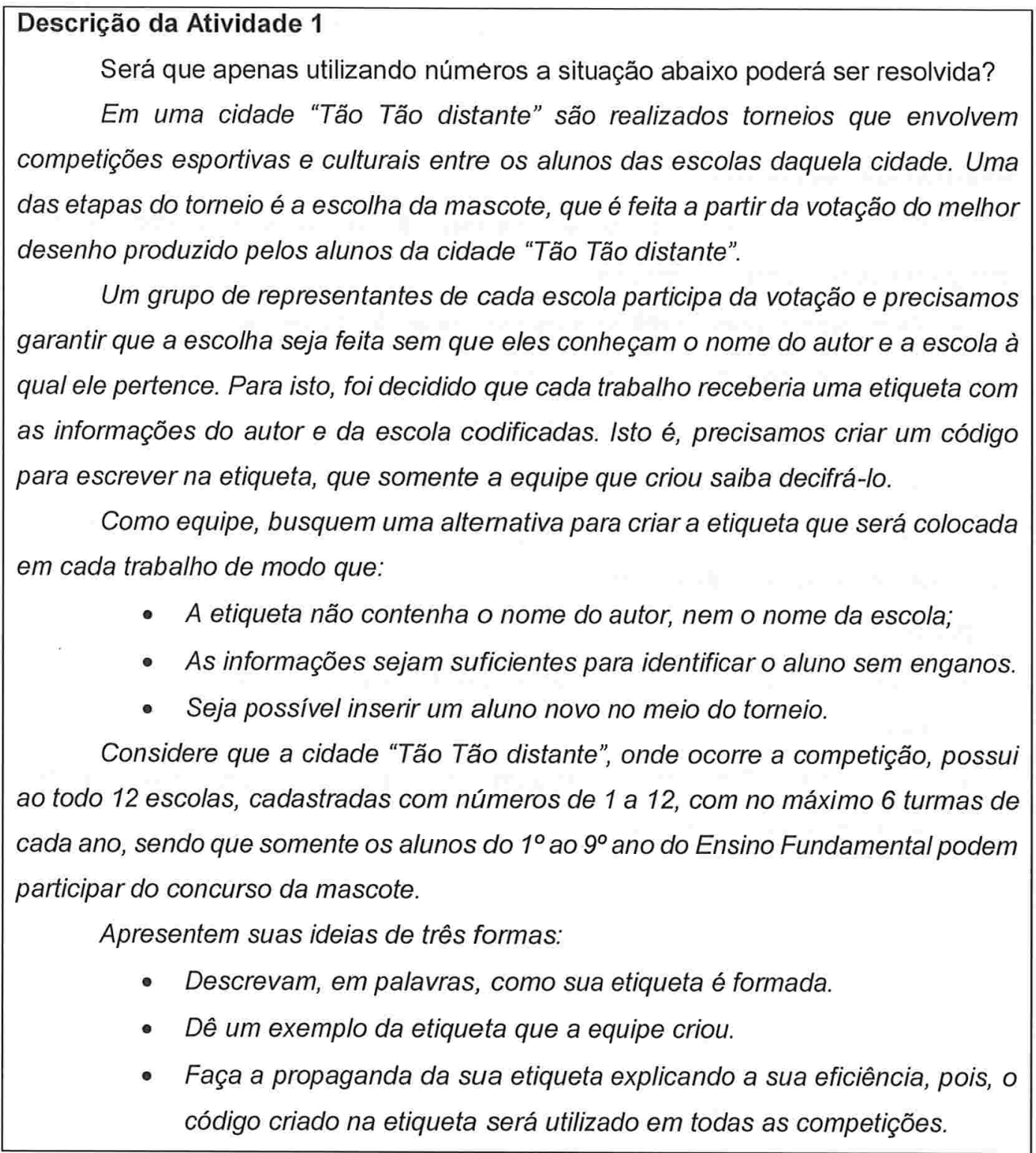

\section{Análise a priori}

Para a elaboração do código, os alunos devem identificar quais informações são necessárias em cada etiqueta (escola, ano, turma e aluno) e quantos dígitos são suficientes para cada uma dessas informações. 
Os alunos devem prestar atenção à sequência criada, de forma a desenvolver um padrão e manter a eficiência. Além disso, devem perceber que o excesso de informações pode tornar um código inviável.

\section{Resultados esperados:}

Ao término da atividade os alunos deverão ter criado uma etiqueta contendo um código de seis dígitos, sendo que:

- Dois dígitos para codificar a escola, pois são 12 escolas;

- Um dígito para o ano escolar, de $1^{\circ}$ a $9^{\circ}$ ano;

- Um dígito para a turma, pois são no máximo seis turmas por ano;

- Dois dígitos para o número de chamada.

Caso os alunos não tenham atingido os objetivos, fornecer elementos necessários para que se conclua a atividade.

Sugestões:

- Quantos dígitos são necessários para cadastrar o número de chamada de um aluno?

- Que informações são necessárias no código para que se possa identificar um aluno de qualquer escola? 


\section{Etapa 2}

Essa etapa deve ser realizada no início da aula seguinte à aplicação da etapa 1. O tempo previsto é de 30 minutos, podendo variar de acordo com as resoluções e discussões apresentadas pelas equipes. A finalidade dessa atividade é, a partir da discussão com toda a turma, sistematizar os objetivos da Etapa1, ou seja:

- Reconhecer que os números podem ser utilizados como codificadores.

- É possivel associar um número a cada informação do problema.

- Criar um código de identificação que atenda às necessidades do problema e que será utilizado nas próximas atividades.

Para isso, são retomadas as informações do problema e podem ser feitas aos alunos algumas perguntas:

1. Que informações o código deve conter para que se possa identificar um aluno de qualquer escola?

2. Para se cadastrar o número da escola, quantos dígitos no máximo são necessários?

3. Como cadastrar a escola de número 4, por exemplo, utilizando dois dígitos?

4. Como cadastrar a turma a qual o aluno pertence usando apenas algarismos? Por exemplo, como cadastrar um aluno do $7^{\circ} \mathrm{C}$ ?

5. Quantos dígitos são necessários para cadastrar o número do aluno?

6. Imagine cadastrar todos os alunos participantes do concurso. É viável acrescentar alguma informação ao código que não seja necessária para a identificação do aluno? 


\section{Atividade 2}

\section{Etapa 1}

O tempo previsto: 30 minutos de uma aula.

Organização da turma: Sugerimos que sejam mantidas as equipes formadas na Atividade 1.

Os principais objetivos dessa etapa são:

- Atribuir dígitos de verificação ao código de identificação visando a detectar um único erro de digitação.

- Conhecer a existência de processos de detecção de erros em documentos como, CPF e RG.

- Efetuar, a critério de cada equipe, uma ou mais operações matemáticas com os próprios algarismos do código para atribuir a ele dígitos de verificação.

- Analisar e testar a eficiência do algoritmo criado pela equipe quando ocorrer um único erro de digitação.

Na sequência, será apresentada a atividade a ser proposta aos alunos, a análise a priori e os resultados esperados.

\footnotetext{
Alguns alunos participantes do Torneio, sabendo que cada trabalho receberia uma etiqueta contendo apenas números, perceberam que havia a possibilidade de o código ser digitado erroneamente e questionaram sua confiabilidade. Para eles, bastaria digitar um único algarismo do código errado que, provavelmente, alteraria o resultado da premiação. Na opinião deles, apenas a identificação nominal seria confiável.

Como equipe, analisem a seguinte situação e verifique se é possível tornar o código confiável:

Supondo que o trabalho escolhido foi o do aluno Marcos do $6^{\circ}$ ano A do colégio 12. Infelizmente, a secretária Márcia digitou o código 116125 ao invés de 126125. Neste caso, o aluno Nathan do colégio 11 receberia o prêmio.

Existe alguma maneira de se detectar esse tipo de erro, de um único dígito, cometido na digitação?

Visando à segurança, alguns documentos possuem dígitos no final de seu código para detectar possíveis erros de digitação. Esses são chamados de dígitos de
} 
verificação e são determinados através de operações matemáticas realizadas com os próprios dígitos do código. Alguns como o RG usam um dígito de verificação, outros, como o CPF, usam dois. Por exemplo, quando o CPF é digitado numa nota fiscal, o sistema utiliza certas regras para calcular os dígitos verificadores e em seguida, compara-os com os dígitos verificadores que foram digitados. Então, se o digitador cometer um erro, por engano, o sistema possivelmente acusará, pois os algarismos dos dígitos encontrados através do cálculo, muito provavelmente, serão diferentes dos dígitos verificadores do CPF digitado.

Como equipe, busquem uma alternativa, acrescentando na etiqueta, um ou mais algarismos, que sirvam de verificadores para detectar um possível erro na digitação do código do aluno. Utilizem o código do aluno Marcos, 126125, e efetuem uma ou mais operações básicas, tais como adição, subtração, multiplicação, divisão, com os algarismos 1, 2, 6, 1, 2 e 5 para determinar o(s) dígito(s) de verificação.

Apresentem suas ideias comentando:

- Que operações matemáticas a equipe realizou com os algarismos do código 126125 e quais serão os dígitos de verificação? Expliquem como serão determinados os digitos?

- Será possível conferir o código de qualquer aluno? Como será feita a verificação?

- Se houver um erro de digitação num único dígito, sempre será detectado? E se o erro estiver no dígito de verificação?

\section{Análise a priori}

Os alunos devem definir quais operações matemáticas serão realizadas, com os próprios algarismos do código, para gerarem os dígitos de verificação. Eles devem verificar se, com esses dígitos atribuídos, é possível conferir cada código, de modo a detectar a existência de um erro de digitação. Devem, ainda, testar a eficiência do algoritmo criado.

\section{Resultados Esperados}

Ao final dessa atividade, os alunos deverão ter criado um algoritmo, com os algarismos do código, para gerar os dígitos verificadores. Esses dígitos deverão possibilitar a detecção de um erro de digitação num único dígito. 


\section{Conceitos matemáticos envolvidos}

Operações fundamentais:

Adição, subtração, multiplicação, divisão.

\section{Etapa 2}

Esta etapa pode ser aplicada no início da aula seguinte à aplicação da etapa 1. O tempo previsto é de 20 minutos podendo variar de acordo com as sugestões e questionamentos das equipes. Os principais objetivos são:

- Compreender a finalidade de dígitos verificadores em códigos de identificação.

- Entender que um único erro de digitação pode ser detectado com a utilização de dígitos verificadores.

- Discutir e validar a eficiência do algoritmo criado por cada uma das equipes para a detecção de um único erro de digitação.

- Perceber que a atribuição de dígitos verificadores a um código de identificação possibilita sua conferência.

Para isso, os alunos apresentam o algoritmo desenvolvido pela equipe e estes são analisados e testados supondo que ocorra um único erro de digitação.

\section{Atividade 3}

\section{Etapa 1}

O tempo previsto: 30 minutos de uma aula.

Organização da turma: Essa atividade poderá ser realizada em duplas.

Os principais objetivos são:

- Compreender como desenvolver um algoritmo que possibilite atribuir ao código um único dígito de verificação. 
- Perceber que a construção do algoritmo, leva à utilização de múltiplos de um número base e que sua escolha é influenciada pela quantidade de restos distintos possíveis, ao se dividir por este número.

- Perceber que um erro num único dígito pode ser detectado, utilizando, no algoritmo de detecção, a operação de adição com os algarismos do código.

- Compreender que erros de troca de posição de algarismos consecutivos, não são detectados apenas utilizando a operação de adição no algoritmo de detecção.

A seguir, apresentaremos a atividade a ser proposta aos alunos, a análise a priori e considerações sobre o que é esperado ao final da atividade.

Descrição da Atividade 3

Um aluno, muito curioso, também participante do concurso, querendo desvendar o mistério dos dígitos verificadores para provar que a etiqueta de identificação poderia ser confiável, pesquisou na internet como são calculados os dígitos de verificação de alguns códigos. Na sua pesquisa, ele encontrou algumas sequencias de operações matemáticas, ou seja, algoritmos que, aplicados aos algarismos do código, determinam um único dígito verificador. Baseado nas suas pesquisas, esse aluno apresentou aos colegas um algoritmo que, segundo ele, geraria um único dígito de verificação para conferir cada código e assim evitaria erro nas premiações.

A sugestão foi:

1. Escolha um número natural, como base.

2. Some todos os algarismos do código, chamaremos de $\mathbf{S}$ a soma obtida.

3. O algarismo do dígito verificador de cada código é o valor que somado com $S$ resulta em um múltiplo do número base.

4. Desta forma, a soma de todos os algarismos, incluindo o dígito de verificação do código de qualquer aluno, será sempre um múltiplo desse número base.

5. Se a soma obtida for um múltiplo do número escolhido, então o digito de verificação desse código será igual à zero.

6. Como se detecta um erro?

Observe que, se a soma de todos os algarismos (com o dígito) não for múltiplo do número escolhido, há um erro. 
Vamos experimentar como número base o número 8.

- Como equipe, calculem o dígito verificador do aluno 128322.

O código com o dígito de verificação é: $128322-$

Observe que, a soma de todos os algarismos, incluindo o dígito de verificação do código, será sempre um múltiplo desse número base.

Verifique se o algoritmo sugerido funciona quando há um erro num único dígito, nos seguintes casos:

- E se o vencedor fosse o aluno 128322 e, por engano, a pessoa digitasse 128328.

a) Qual foi o erro cometido?

b) Neste caso, utilizando o múltiplo de 8 , esse erro é detectado?

- E se ela digitasse 108515 ao invés de 103515 .

a) Qual foi o erro cometido?

b) Neste caso, utilizando o múltiplo de 8, esse erro é detectado?

- E para este outro erro: 061511 ao invés de 061519 .

a) Qual foi o erro cometido?

b) Neste caso, utilizando o múltiplo de 8, esse erro é detectado?

- Verifiquem se o algoritmo funciona quando o número base é 10.

Intrigados com o algoritmo apresentado, os alunos resolveram pesquisar sobre os tipos de erros. Foi então que, um aluno preocupado perguntou se o algoritmo funcionaria para o caso em que, o erro fosse de apenas trocar a posição (ordem) de dois algarismos quaisquer do código?

Como equipe, analisem então esta outra possibilidade que também poderia ocorrer: Supondo que a secretária Márcia tenha digitado o código 126215 ao invés de 126125. Como equipe:

- Qual foi o erro cometido?

- Utilizando o algoritmo, será possível detectar o erro? Por quê?

- Sugiram um algoritmo para detectar esse tipo de erro. 


\section{Análise a priori}

Para que se possa atribuir um único dígito de verificação, a atividade sugere um algoritmo. Para desenvolver esse algoritmo, os alunos devem definir um número natural como base e determinar seus múltiplos. Em seguida, devem somar os algarismos do código e essa soma deve ser subtraída do múltiplo do número base imediatamente superior a ela, gerando assim, o dígito verificador.

Os alunos devem testar a eficiência desse algoritmo para o número base 8 e o número base 10 na detecção de um único erro de digitação. Além disso, é solicitado que testem o algoritmo, para o caso em que, o erro fosse de apenas trocar a posição (ordem) de dois algarismos quaisquer do código.

\section{Resultados Esperados}

- Ao término desta atividade espera-se que o aluno entenda que:

- Dígitos verificadores são atribuídos a códigos identificadores, visando a sua segurança e conferência, através da utilização de conceitos matemáticos relacionados a divisibilidade.

\section{Conceitos matemáticos envolvidos}

- Adição de números naturais.

- Subtração de números naturais.

- Múltiplos de um número natural.

- Propriedade comutativa.

\section{Etapa 2}

O tempo previsto: 15 minutos de uma aula.

O principal objetivo desta etapa é verificar se os alunos:

- Compreenderam o algoritmo que permite atribuir um único dígito verificador ao código.

- Perceberam que o número base é o que proporciona a quantidade de dígitos verificadores ao código. 
- Entenderam que se houver apenas um único erro de digitação, ele poderá ser detectado usando a operação de adição com os algarismos do código.

- Perceberam que a quantidade de dígitos de verificação disponível depende do número base escolhido, pois é igual à quantidade de restos distintos possíveis quando se divide por este número.

\section{Atividade 4}

\section{Etapa 1}

O tempo previsto: uma aula de 30 minutos.

Organização da turma: A atividade poderá ser realizada em duplas.

Os principais objetivos são:

- Conhecer o processo de detecção de erros utilizado em códigos de barras.

- Compreender o algoritmo utilizado em código de barras para atribuir o dígito verificador.

- Aplicar o processo de detecção de erros no código desenvolvido na Atividade 1.

A seguir, será apresentada a atividade a ser proposta aos alunos e considerações.

\section{Descrição da Atividade 4}

O aluno curioso, percebendo que seu algoritmo não funcionava em todos os casos, retomou sua pesquisa sobre códigos e apresentou outra sugestão que também é utilizada em códigos identificadores. O algoritmo consiste em:

- Escrever abaixo de cada dígito do código identificador os algarismos 1, 3, começando pelo primeiro algarismo do código, repetindo-os, sucessivamente.

- Multiplicar cada dígito do código identificador pelo algarismo que está abaixo.

- Somar todos os produtos obtidos. 
- Buscar o primeiro múltiplo de 10 e imediatamente superior ao resultado obtido na soma.

- O dígito verificador é o valor necessário para que, somado com os algarismos do código resulte em um múltiplo de 10.

Como equipe:

Utilizem o novo algoritmo e testem sua eficiência. Verifiquem se com esse algoritmo será possível detectar esses erros:

- Se ela digitasse 126215 ao invés de 126125 . O erro poderia ser detectado?

- E se o ganhador fosse o aluno 073519 e, sem querer, ela digitasse 037519 ?

Verifique se o erro seria detectado.

- Se houver a troca de posição (ordem) de dois algarismos quaisquer do código, sempre será detectado?

Desconfiados do novo algoritmo, os alunos continuaram a pesquisar possíveis erros de digitação que podem ser cometidos e, novamente, lançaram um desafio:

E se o erro fosse trocar a posição (ordem) de dois algarismos seguidos quaisquer do código cuja diferença entre o maior e o menor seja 5 . Esse tipo de erro será detectado?

Supondo que a secretária Márcia tenha digitado o código 121625 ao invés de 126125.

Como equipe:

- Utilizem o algoritmo. Neste caso, será possível detectar o erro?

\section{Análise a priori}

Para que os alunos entendam como é o processo de detecção de erros utilizados em códigos de barras, foi explicado, detalhadamente, o algoritmo que permite atribuir a ele um dígito verificador. 
Em seguida, é solicitado aos alunos que apliquem o algoritmo no código elaborado na atividade 1 e testem sua eficiência na detecção de erros. Para isso, são propostas situações nas quais ocorrem erros de transposição de algarismos consecutivos na digitação de um código. Em especial, os alunos deverão testar um caso específico em que a utilização do número 10 como número base não permite a detecção de erros.

\section{Resultados Esperados}

Após a realização desta atividade, espera-se que os alunos:

- Entendam o algoritmo utilizado em códigos de barras para detectar possíveis erros de digitação.

- Percebam que alguns tipos de erros de transposição de algarismos consecutivos, na digitação de um código de identificação, podem não ser detectados dependendo do número base escolhido.

\section{Conceitos matemáticos envolvidos}

- Adição de números naturais.

- Multiplicação de números naturais.

- Múltiplos de um número natural.

\section{Etapa 2}

O tempo previsto: 15 minutos de uma aula.

Retomar o algoritmo sugerido na Etapa 1 e discutir com os alunos:

- Como aplicá-lo e como utilizá-lo em um código.

- Sua eficiência na detecção de erros.

- Que alterações podem ser feitas no algoritmo, principalmente em relação ao número base, visando a proporcionar maior detecção de erros. 


\section{Atividade 5}

\section{Etapa 1}

O tempo previsto: 20 minutos de uma aula.

Organização da turma: A atividade poderá ser desenvolvida em duplas ou individualmente.

Essa etapa tem como objetivo:

- Compreender e aplicar o algoritmo sugerido na atividade.

- Perceber que a utilização de um número primo, em determinados algoritmos, pode proporcionar maior detecção de erros.

A seguir, mostraremos a atividade a ser proposta aos alunos, a análise a priori e o que se espera ao término dessa etapa.

\section{Descrição da Atividade 5}

Diante do desafio proposto pelos alunos, outro aluno interessado disse já ter lido em suas pesquisas que, alguns códigos identificadores e, principalmente, as senhas bancárias, utilizam em seus algoritmos números primos, pois com eles é possível detectar erros. Sendo assim, sugeriu uma alternativa: Utilizar múltiplos de números naturais primos.

O algoritmo ficou assim:

- Escrever abaixo de cada dígito do código identificador os algarismos 1 e 3, começando pelo primeiro algarismo do código, repetindo-os, sucessivamente.

- Multiplicar cada dígito do código identificador pelo algarismo que está abaixo.

- Somar todos os produtos obtidos.

- O dígito verificador será o valor necessário para que, adicionado à soma obtida, resulte em um múltiplo de 11.

- Se o valor necessário for 10 , então o dígito verificador será a letra $X$.

Como equipe:

Utilizem o algoritmo e verifiquem se com esse algoritmo conseguiríamos detectar os possíveis erros de digitação: 


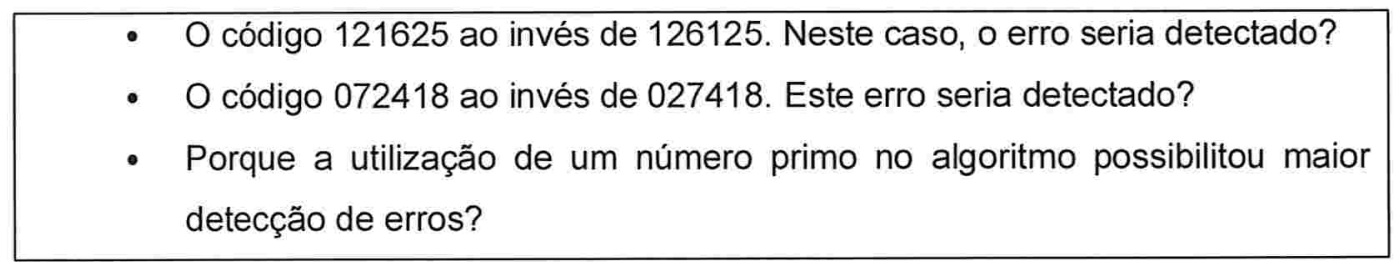

\section{Análise a priori:}

Nesta atividade, o aluno conhecerá um algoritmo similar ao que foi sugerido na atividade anterior, mas que utiliza um número primo como número base.

É solicitado ao aluno que verifique se essa alteração torna o algoritmo mais eficiente. Para isso, o aluno deverá aplicar o algoritmo nos problemas da atividade anterior, na qual a utilização do número 10 como número base, não possibilitou a detecção de erros.

\section{Resultados Esperados}

Ao final dessa atividade, o aluno deverá ter entendido quais conceitos matemáticos podem ser utilizados em códigos identificadores. Além disso, deve perceber que, em determinados algoritmos, a utilização de número primos possibilita melhores resultados.

\section{Etapa 2}

O tempo previsto: 15 minutos de uma aula.

Essa etapa tem como objetivo verificar se os alunos:

- Compreenderam o algoritmo sugerido na atividade.

- Entenderam que a substituição por um número primo, no algoritmo, pode proporcionar maior detecção de erros.

- Perceberam o papel de conceitos matemáticos, especificamente números primos, na elaboração de códigos de identificação.

\section{Atividade 6}

\section{Etapa 1}

O tempo previsto: Uma aula de 50 minutos.

Organização da turma: A atividade poderá ser realizada em duplas.

Os principais objetivos dessa etapa são: 
- Deduzir quais informações trazem os códigos de barras EAN-13 e como são organizadas.

- Determinar o dígito verificador de um código de barras EAN-13.

- Compreender a importância de conceitos matemáticos na elaboração e segurança de um código de barras como o EAN-13.

Abaixo, apresentamos a atividade a ser proposta aos alunos, a análise a priori e considerações sobre o que é esperado com a realização da atividade.

\footnotetext{
Atividade 6: Conhecendo o código de barras

O Código de barras é uma tecnologia que tornou o dia a dia dos comerciantes muito mais simples. Imagine em um supermercado, antigamente ao receber as mercadorias, era necessário colocar os preços manualmente em todos os produtos, anotar item a item para controlar a quantidade no estoque e ainda o operador do caixa digitava valor a valor, produto a produto.

Atualmente, todos os produtos industrializados trazem impressos na embalagem um código de barras. Ao apontar esse código para uma máquina leitora ótica é possível obter o preço e a quantidade no estoque de forma automática, além de todas as outras informações necessárias para a comercialização do produto.

Que informações trazem esses códigos e como são organizadas?

Nesta atividade você deve observar e comparar o código de barras de cada produto e assim poderá perceber que tipo de informações trazem esses códigos.

Cada produto possui um código de barras com 13 algarismos. Ao observar cada código procure separá-lo em partes, ou seja,

- $\quad 1^{\text {a }}$ parte: com os 3 primeiros algarismos

- $\quad 2^{a}$ parte: com os 4 algarismos seguintes

- $3^{\text {a }}$ parte: com os próximos 5 algarismos

- $4^{a}$ parte: será apenas o último algarismo do código.
}

Observe os seguintes produtos com os seus respectivos códigos de barra e analise as informações dadas: 
- Achocolatado produzido no Brasil

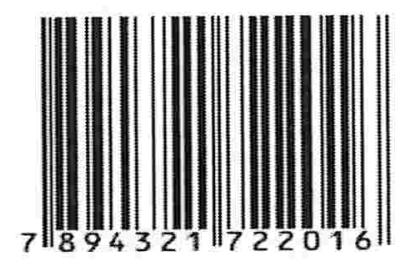

- Suco produzido no Brasil

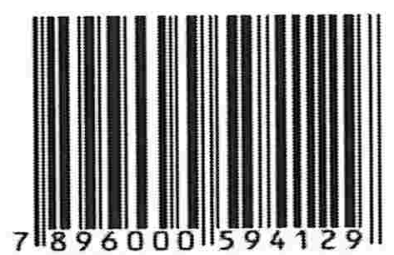

- Queijo ralado produzido no Brasil



- Margarina produzida na Grécia

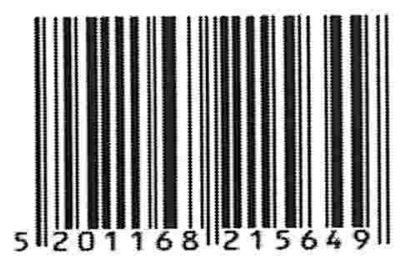

- Azeite produzido na Grécia

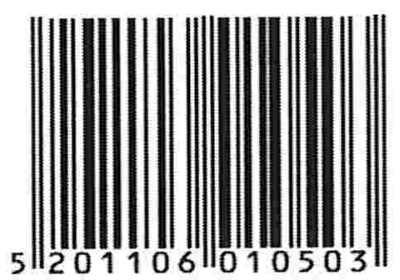


- Manteiga produzida na França



- Queijo produzido na França

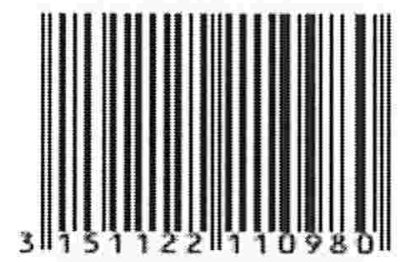

Comparando os códigos de barras acima você chegou a alguma conclusão sobre que informação contém os três primeiros algarismos?

Com as imagens abaixo você terá condições de continuar sua investigação e deduzir quais são as outras informações contidas nos códigos de barras.

- Creme de leite e leite integral: ambos produzidos pela mesma empresa brasileira:

\begin{tabular}{|c|c|}
\hline Creme de Leite & Leite Integral \\
\hline
\end{tabular}
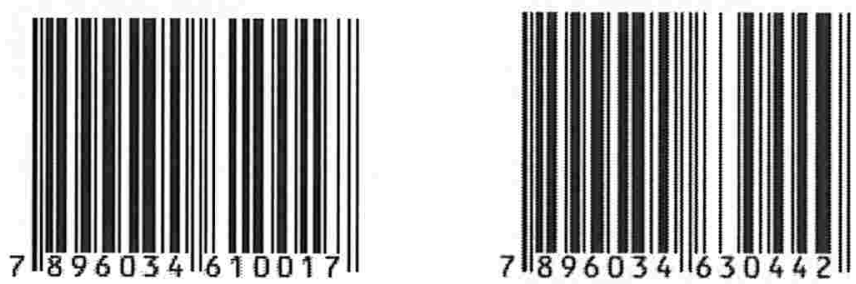

- Achocolatado e logurte Natural: ambos produzidos pela mesma empresa brasileira 


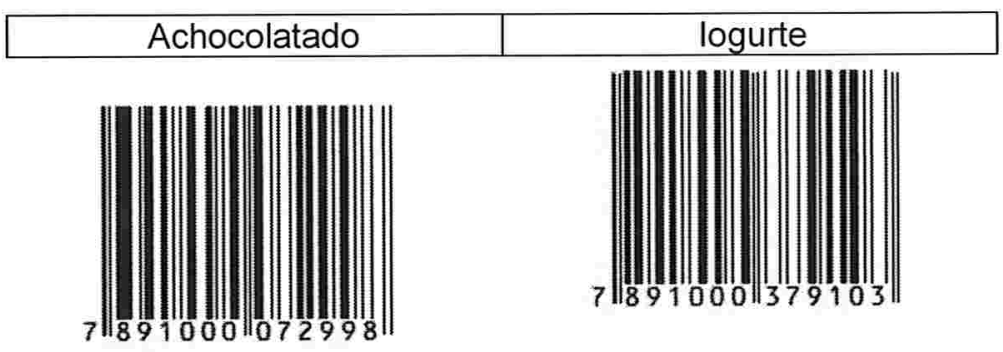

- Queijo tipo Petit Suisse e logurte Líquido: ambos produzidos pela mesma empresa brasileira:

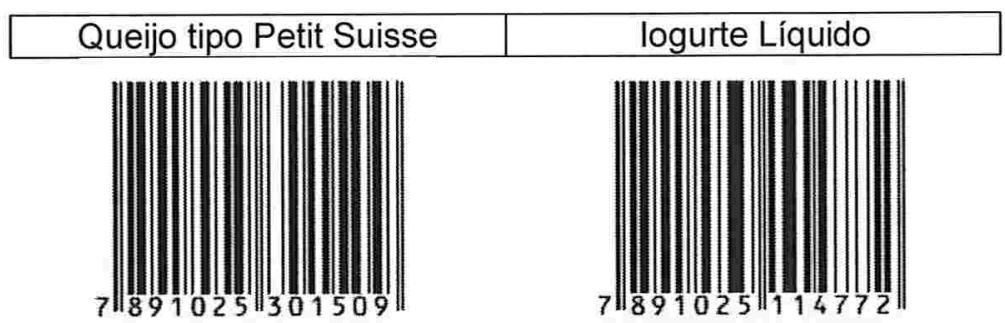

- Pão Integral e Bisnaguinha: ambos produzidos pela mesma empresa brasileira:

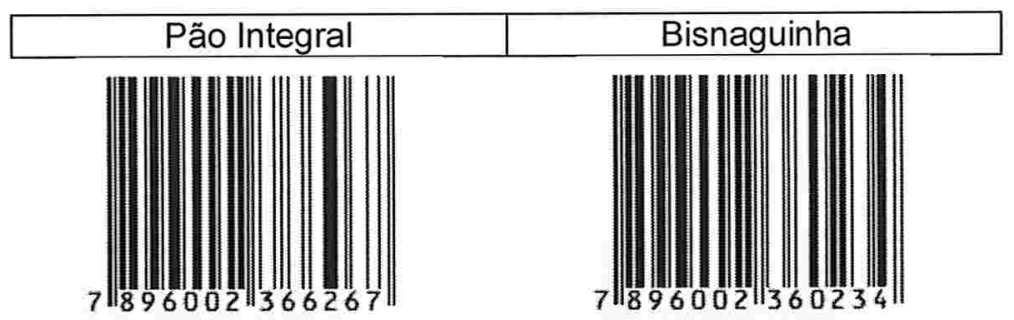

É possivel chegar a alguma conclusão em relação a que informação contém os 4 algarismos da $2^{\mathrm{a}}$ parte do código de barras?

Com os produtos abaixo você poderá tirar conclusões sobre a $3^{\mathrm{a}}$ parte do código de barras. Os três códigos são de bolinhos produzidos pela mesma empresa, nos sabores: 


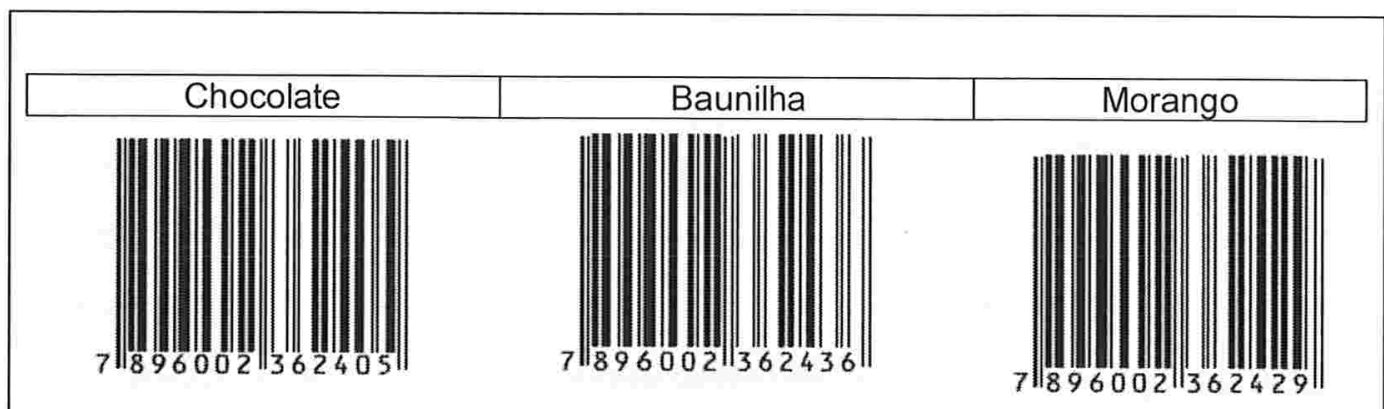

E em relação aos 5 algarismos da $3^{\mathrm{a}}$ parte do código de barras, você chegou a alguma conclusão? Que informação ela contém?

O último algarismo do código é um dígito verificador e é determinado através de operações matemáticas utilizando os 12 algarismos iniciais.

Vejamos como se calcula o dígito verificador.

Analisando o código de barras do produto abaixo, observamos que o seu dígito verificador é igual a 5. Apliquem o algoritmo abaixo e verifiquem como se obtém tal resultado.

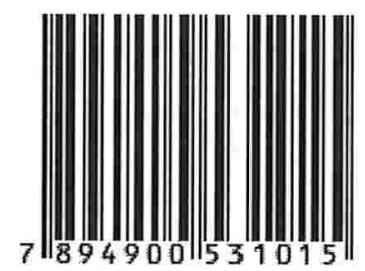

1.Comecem escrevendo a sequência dos 12 dígitos do código e abaixo deles, começando pelo primeiro, a sequência $1,3,1,3,1,3, \ldots$

\begin{tabular}{|l|l|l|l|l|l|l|l|l|l|l|l|}
\hline 7 & 8 & 9 & 4 & 9 & 0 & 0 & 5 & 3 & 1 & 0 & 1 \\
\hline 1 & 3 & 1 & 3 & 1 & 3 & 1 & 3 & 1 & 3 & 1 & 3 \\
\hline
\end{tabular}

2. Calcule todos os produtos, ou seja, multiplique cada algarismo do código identificador pelo número que está abaixo.

3. Some todos os produtos obtidos.

4. O algarismo do dígito verificador é o valor necessário para que adicionado à soma obtida resulte em um múltiplo de 10 . Verifiquem que o dígito verificador, desse código de barras, é o algarismo 5.

Exercício:

Determinem o dígito verificador do seguinte código de barras:

789102570010 


\section{Análise a priori}

Para que se possa deduzir quais informações trazem os códigos de barra, os alunos devem observar e comparar cada produto com seu respectivo código de barras. Assim, eles devem separar cada código em quatro partes, agrupando os algarismos de acordo com as orientações da atividade, ou seja,

- $1^{a}$ parte: com os 3 primeiros algarismos

- $2^{\mathrm{a}}$ parte: com os 4 algarismos seguintes

- $\quad 3^{a}$ parte: com os próximos 5 algarismos

- $4^{a}$ parte: será apenas o último algarismo do código.

Os alunos devem analisar cada parte juntamente com a informação dada sobre o produto.

\section{Resultados esperados}

Ao concluir esta atividade, espera-se que o aluno tenha percebido que a aplicação de conceitos matemáticos possibilita a segurança dos códigos de barras utilizados nos produtos para sua comercialização.

Os alunos deverão ter entendido quais informações estão codificadas em cada uma das partes, ou seja,

- $1^{\mathrm{a}}$ parte: o país onde o produto está registrado

- $2^{a}$ parte: o fabricante do produto

- $3^{\mathrm{a}}$ parte: o próprio produto

- $4^{\mathrm{a}}$ parte: dígito verificador

E ainda, eles deverão saber atribuir o dígito de verificação de um código de barras.

\section{Etapa 2}

O tempo previsto: 15 minutos de uma aula, podendo variar de acordo com os questionamentos dos alunos.

Os principais objetivos são: 
- Discutir quais e como são organizadas as informações contidas nos códigos de barras EAN-13.

- Verificar se houve a compreensão do algoritmo.

- Discutir o papel de conceitos matemáticos no algoritmo de detecção de erros.

- Analisar se a utilização de um número primo no algoritmo possibilitaria melhor detecção de eventuais erros de digitação.

\section{Atividade 7}

\section{Etapa 1}

O tempo previsto: uma aula de 20 minutos.

Organização da turma: A atividade poderá ser realizada em duplas ou individualmente.

Os principais objetivos são:

- Mostrar como é constituído o Cadastro das pessoas físicas na Receita Federal CPF.

- Explicar como são calculados os dígitos de verificação de um CPF, visando à detecção de erros de digitação.

- Aplicar o algoritmo para determinar os dígitos verificadores de um CPF.

- Perceber o papel de conceitos matemáticos, tais como múltiplos, números primos, etc., na elaboração do CPF.

Apresentaremos a seguir a atividade a ser proposta aos alunos. 


\section{Descrição da Atividade 7:}

Cadastro das pessoas físicas na Receita Federal - CPF

O número do CPF de uma pessoa, no Brasil, é constituído por 11 algarismos, sendo que os 8 primeiros se referem ao número de inscrição da pessoa física no Cadastro Individual do Contribuinte. O nono algarismo indica a região onde foi efetuada a inscrição, por exemplo, inscrições efetuadas em São Paulo terão o dígito 8. E os dois últimos algarismos do CPF, ou seja, o décimo e o décimo primeiro são dígitos de verificação. Estes dígitos de verificação também são determinados através de operações matemáticas realizadas com os próprios algarismos do CPF.

O algoritmo para se calcular o décimo algarismo (o primeiro dígito verificador) é:

- Cada um dos nove algarismos, começando pelo primeiro, será multiplicado sucessivamente por $1,2,3,4,5,6,7,8,9$ (o primeiro por 1 , o segundo por 2 , o terceiro por 3 , e assim por diante).

- Some todos os produtos resultantes.

- Divida a soma obtida por 11.

- O primeiro dígito verificador (o décimo algarismo) será o resto desta divisão.

- Se o resto for igual a 10 , o digito verificador será 0 .

O algoritmo para se calcular o décimo primeiro algarismo (o segundo dígito verificador) consiste em:

- Cada um dos dez algarismos, incluindo o décimo algarismo (o que acabamos de calcular), começando pelo primeiro, será multiplicado sucessivamente por $0,1,2,3$, $4,5,6,7,8,9$.

- Some todos os produtos resultantes.

- Divida a soma obtida por 11.

- O segundo dígito verificador (o décimo primeiro algarismo) será o resto desta divisão.

Como equipe, utilizem o algoritmo para resolverem o problema:

1) Paulo vai comprar um presente para sua esposa. Pretende ao efetuar o pagamento, pedir a nota fiscal com o CPF dela, mas, infelizmente, só consegue lembrar os nove primeiros algarismos que são 987.654.321. Quais são os dígitos verificadores do CPF da esposa de Paulo? 


\section{Análise a priori}

O algoritmo utilizado pela Receita Federal para detectar possíveis erros de digitação é descrito para que o aluno possa compreender como são atribuídos os dígitos de verificação de um CPF. Em seguida, um problema é proposto para a aplicação desse algoritmo.

Os alunos deverão perceber que a atribuição dos dígitos verificadores a um CPF é um mecanismo de segurança, pois possibilita sua conferência, que depende de conceitos relacionados com divisibilidade de números inteiros.

\section{Resultados Esperados}

Ao final dessa etapa, os alunos deverão compreender a aplicação do algoritmo para atribuir os dois dígitos de verificação de um CPF. Além disso, eles devem entender que os dígitos possibilitam sua conferência.

\section{Etapa 2}

O tempo previsto: 15 minutos de uma aula.

Os principais objetivos desta etapa são:

- Abordar com os alunos as dificuldades, caso ocorram, na aplicação do algoritmo.

- Discutir com os alunos a estrutura do algoritmo. Questionar se os fatores diferentes na multiplicação dos algarismos, e a utilização de um número primo como número base no algoritmo possibilitam maior detecção de erros.

- Questionar como é possível conferir um CPF com a utilização dos dígitos verificadores. 


\section{RESULTADO DAS ATIVIDADES APLICADAS}

As atividades foram aplicadas numa escola da rede particular da cidade de São Paulo, com duas turmas do $7^{\circ}$ ano do Ensino Fundamental II. A opção por essas turmas se deve ao fato de que os conteúdos matemáticos necessários para o desenvolvimento das atividades são, geralmente, abordados até o $6^{\circ}$ ano do Ensino Fundamental II.

\subsection{DESCRIÇÃO DOS RESULTADOS DAS ATIVIDADES APLICADAS}

A sequência didática foi dividida em sete atividades, aplicadas semanalmente, com discussão das resoluções apresentadas pelos alunos no início da aula seguinte à aplicação. As atividades eram discutidas com toda a turma, com os apontamentos necessários, baseados na resolução ou tentativas de resolução apresentadas pelos alunos.

Todas as atividades foram aplicadas sem valor de nota ou participação. Mesmo assim, os alunos demonstraram grande interesse e entusiasmo ao realizar as atividades.

Para a realização de cada atividade todos os alunos recebiam, por escrito, as orientações e tarefas a serem desenvolvidas.

$\mathrm{Na}$ sequência serão apresentados, de forma detalhada, os resultados das aplicações de cada uma das atividades.

\section{Atividade 1}

\section{Etapa 1}

Para realizarem essa atividade, conforme previsto, os alunos se organizaram em equipes com, no máximo, quatro integrantes. Essa atividade foi realizada fora da sala de aula, em "espaço neutro", com o objetivo de possibilitar a discussão apenas entre os integrantes de cada equipe.

Os alunos iniciaram a atividade com entusiasmo. Depois de lerem a atividade começaram a discutir como fariam o código e quais informações deveria conter para que se pudesse identificar um aluno na situação descrita. 
94

Durante a elaboração do código surgiram comentários entre os alunos das equipes como:

Aluno A: "Para o número da chamada só precisamos de dois dígitos, uma classe até o $9^{\circ}$ ano não tem mais que 99 alunos".

Aluno B: "Para a turma do aluno, podemos fazer assim: como a letra A é a primeira do alfabeto, colocamos o número 1, para a letra $B$ o número 2, para o $C o 3$, até a letra F o número 6".

Vamos ilustrar cada situação analisada com uma única imagem, para evitar repetições desnecessárias.

Pudemos observar que:

- As equipes, em geral, conseguiram entender a proposta da atividade, ou seja, que poderiam utilizar os números como codificadores e criaram um código de identificação.

$$
7=7-\operatorname{arcs}
$$



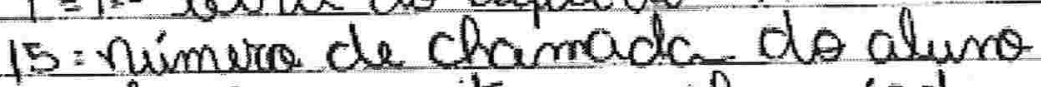
$10=$ rocola escrita na olempiada

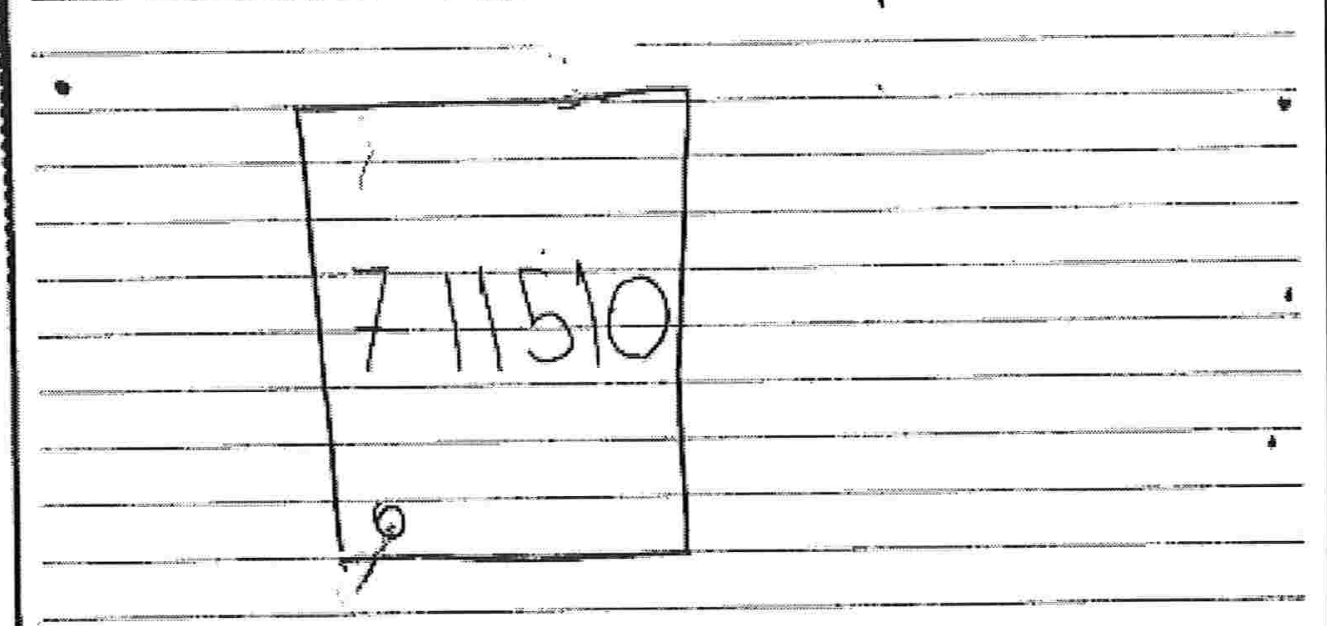

- Ve te tiqueta se organugada, fácil do decorar o cédigo de coda alume epor isso furciona. 
- Algumas equipes conseguiram atribuir corretamente a quantidade de dígitos necessários para cada informação, por exemplo, como são apenas 12 escolas participantes, bastam dois dígitos para que se possa cadastrar qualquer uma delas.

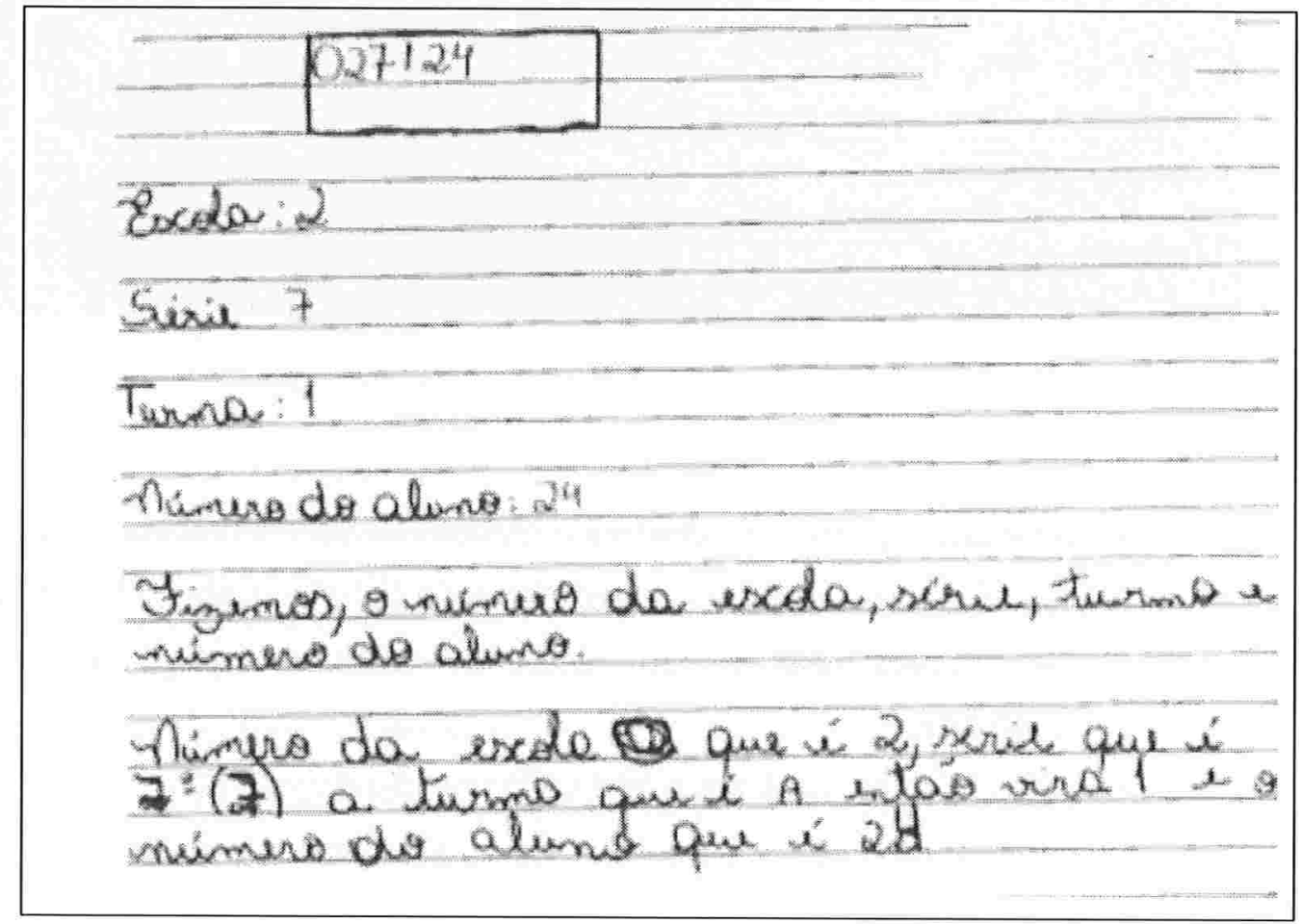

- Embora o problema apresente todas as informações que deveriam ser codificadas, algumas equipes, por não perceberem que estas eram suficientes para a identificação de um aluno, acrescentaram outras ao código, como, por exemplo, data de nascimento, número da sala de aula e etc.

- Algumas equipes tiveram dificuldade em associar uma informação a um número. Para codificarem a turma $(A, B, C, D, E, F)$ a qual o aluno pertence, mantiveram a letra, mesmo sabendo que o código só poderia conter números. 


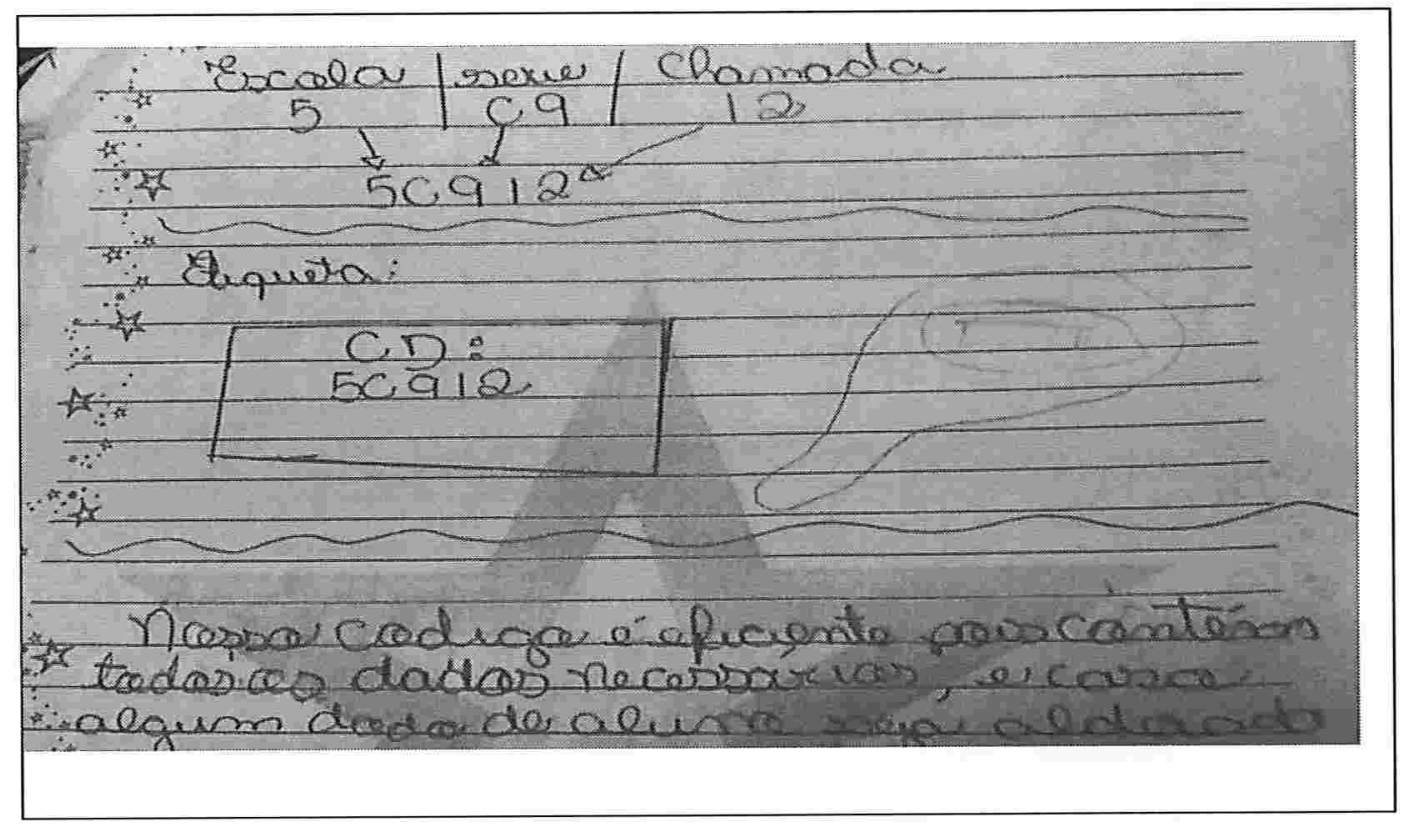

- Uma das equipes, composta por alunos que apresentam bom desempenho escolar, para resolverem essa atividade tentavam associá-la a conteúdos matemáticos que tinham aprendido recentemente e acabaram não resolvendo.

- Os alunos se mostraram motivados no desenvolvimento dessa atividade, em criar um código "secreto", mesmo sabendo que não haveria atribuição de nota. 


\section{Etapa 2}

No início da aula seguinte à aplicação da etapa 1, nas duas turmas, foram recordados alguns dados do problema como a quantidade de escolas participantes, quais e quantas turmas, no máximo, em cada uma delas. Em seguida, foram feitas aos alunos algumas perguntas:

1. Que informações o código deve conter para que se possa identificar um aluno de qualquer uma das escolas participantes?

Os alunos apresentaram as ideias das equipes e pudemos observar que:

- Eles conseguiram identificar que as informações (escola, ano, turma e aluno) são imprescindíveis para a elaboração do código.

- Algumas equipes colocaram a ideia de acrescentarem outras informações como, número da sala de aula, idade e etc.. Nesse momento, foi discutido se seria viável criar um código com excesso de informações. Em uma das turmas surgiu o comentário:

Aluno C: "Se acrescentarmos mais informações o código ficará muito grande e dará muito trabalho na hora de cadastrar os alunos".

Em seguida, foram feitas as outras perguntas com o objetivo de definir a quantidade de dígitos necessária para cada uma das quatro informações.

2. Para se cadastrar o número da escola do aluno, quantos dígitos são necessários?

3. Para se cadastrar o ano e a turma do aluno, quantos dígitos são necessários?

4. E para o número do aluno, quantos dígitos são necessários?

A cada pergunta, um aluno de cada equipe apresentava as ideias do grupo e justificava qual seria a quantidade de dígitos necessária para cada uma das informações. Pudemos observar que:

- Algumas equipes não perceberam que, para o cadastro do número da escola, o código deve ter dois dígitos, independentemente do número da escola. 


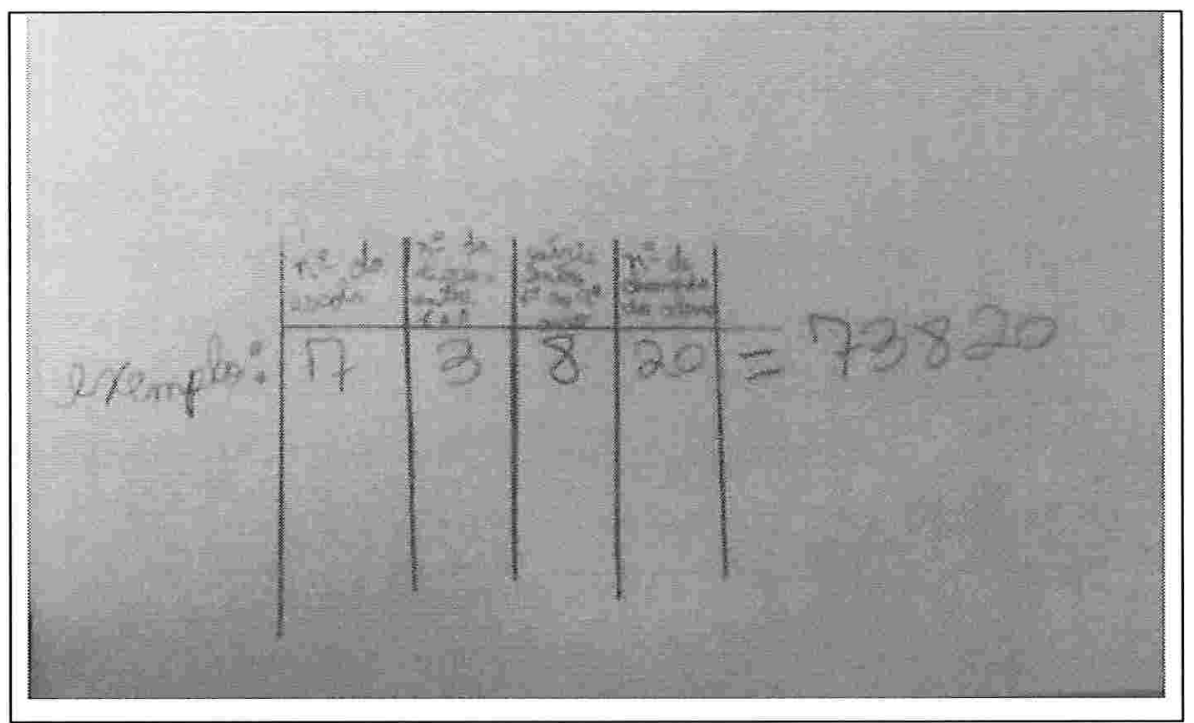

- Os alunos ficaram entusiasmados em explicar o raciocínio utilizado pela equipe para cadastrar cada informação. Eles queriam provar a eficiência de seu código. Uma das justificativas foi:

Aluno D: "Como são 12 escolas, precisamos de dois dígitos para cadastrar qualquer escola".

Dessa forma, ficou definido, nas duas turmas, que o código de identificação teria as seguintes informações: escola, ano, turma e número do aluno.

\section{Atividade 2}

\section{Etapa 1}

Para a realização dessa atividade os alunos mantiveram as mesmas equipes formadas na atividade 1. Essa etapa também foi realizada fora da sala de aula, para favorecer a discussão apenas entre os integrantes de cada equipe.

O tempo previsto de 30 minutos foi suficiente, sendo que algumas equipes terminaram a atividade bem antes do previsto.

Para a elaboração do algoritmo, praticamente, não houve a solicitação do auxilio do professor e pudemos observar que: 
- A maioria das equipes conseguiu atribuir dígitos de verificação ao código, sendo que, algumas delas, efetuaram mais que uma operação matemática.

Erpencacáo do digito de verficacáo:

marcos - codigo $\$ 20119$

- 1"passo isomar os cina primerios numeros

$$
1+2+6+1+1=
$$

11.

- 20 passo pega o resultado firial e multiplica por o ultimo numerio

$11 \times 9=$

99

- 3" passo entáo o digito do verificacáo será os dois ultimos numeros

$$
\text { (99) Codugo de mancos }=126119-99
$$

Outro exemplo:

Natan - codigo 116119

116119

$$
\begin{aligned}
& 10.9 \text { - } \\
& 90 \rightarrow \text { codigo de verificacáó do natam }
\end{aligned}
$$


- Algumas equipes realizaram as operações com os algarismos do código agrupados conforme as informações.

- Deomanos u inúmeres douchlegio main

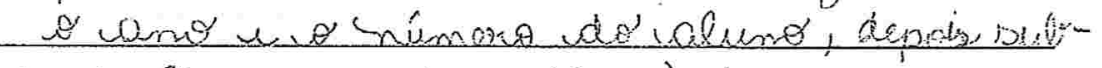
traimos pel'o número (liro) do jurmo,

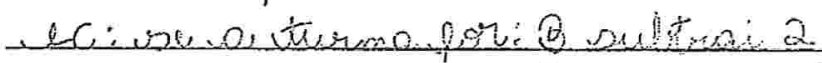

C sultingi3

1) sulitioi 4

Q sulptrais

i subticai 6

- As equipes justificaram como o código pode ser conferido, caso ocorra um erro de digitação, com a utilização do dígito verificador atribuído por eles.

- Se haver um erro de dulapáo, 3 mpre

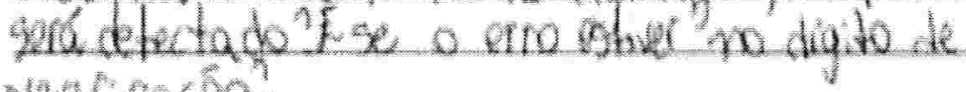
verificatson:

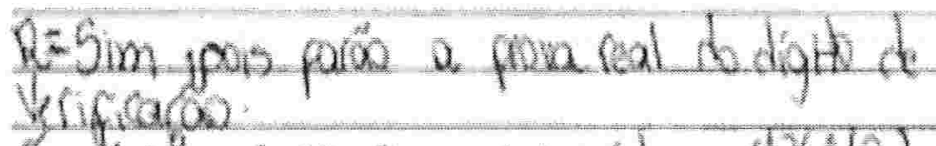



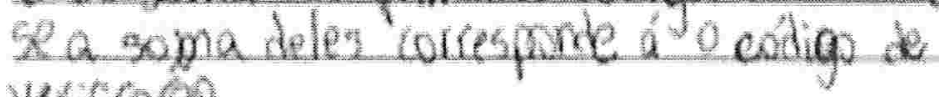
Veriplagn 


\section{Etapa 2}

Foram utilizados 15 minutos de uma aula para a apresentação e discussão da atividade. Cada equipe apresentou o seu algoritmo elaborado para a atribuição de dígitos verificadores ao código e explicaram como conferi-lo.

Embora a atividade proponha um único erro de digitação, duas equipes insistiram na possibilidade de erros de transposição e acabaram surgindo comentários:

Aluno D: "Não adianta somar ou multiplicar os algarismos do código, pois se errarem só invertendo a posição dos algarismos dará o mesmo resultado".

Aproveitou-se então deste comentário para discutir a propriedade comutativa.

Foi questionado então aos alunos:

Que propriedade garante que a ordem das parcelas não altera a soma?

E também: Que propriedade garante que a ordem dos fatores não altera o produto?

\section{Atividade 3}

\section{Etapa 1}

A atividade foi desenvolvida durante 30 minutos de uma aula, com os alunos organizados em duplas.

Desde a primeira atividade, foi combinado com os alunos que, eles tentariam resolvê-las sem a interferência do professor. Mesmo assim, algumas duplas solicitaram o auxílio do professor para que verificasse se haviam entendido o algoritmo, porém outras aceitaram o desafio e resolveram.

Pudemos observar que:

- Os alunos, no geral, conseguiram aplicar o algoritmo, para atribuir um único dígito verificador ao código. 
Alo Dírito do aluno 123222

o codgo con digho de vepteayar 128322

$128322-6$

b) 0 Dígito veriticacer do Ano $135 \%$



$103515-1$

c)

O diaito veriticador to alue 06.519

Orueigo con digito de veringeso O6.519

$06519-2$

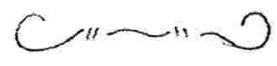

- Conseguiram entender como, verificar a possível existência de algum erro no código utilizando o dígito verificador.

- E se o vencedor fosse o aluno 128322 e, por engano, a pessoa digitasse 128328.

a)Qual foi o erro cometido?

b) Neste caso, utilizando o múltiplo de 8 , esse erro é detectado? 


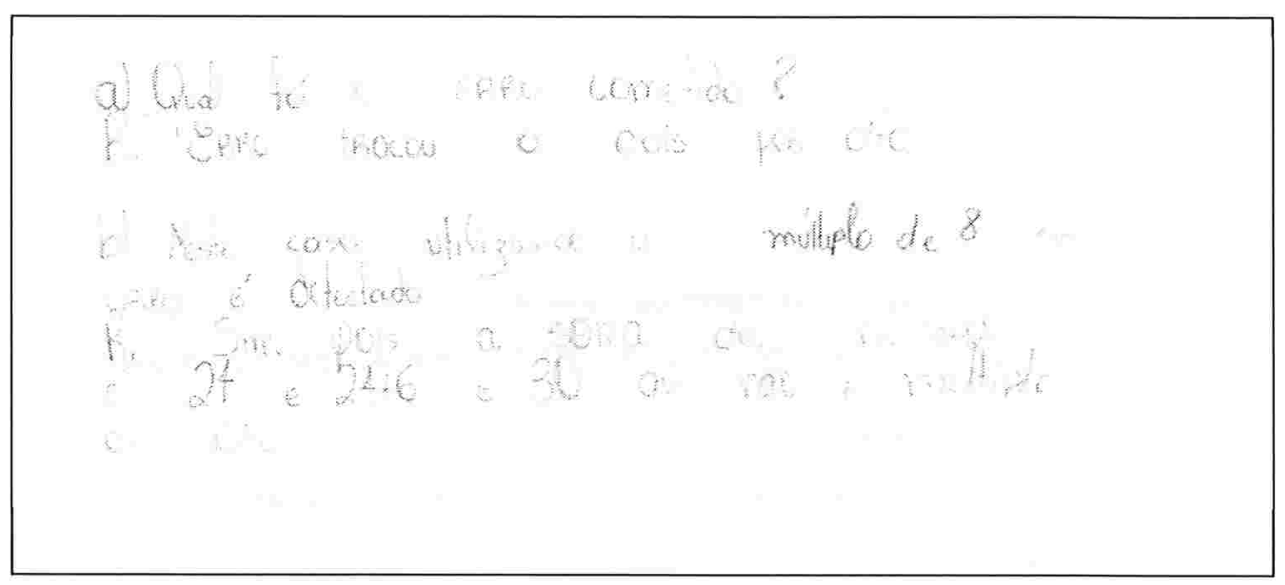

- Ao serem questionados, na atividade, sobre a eficiência do algoritmo em erro do tipo "trocar a posição de algarismos seguidos" uma das duplas respondeu:

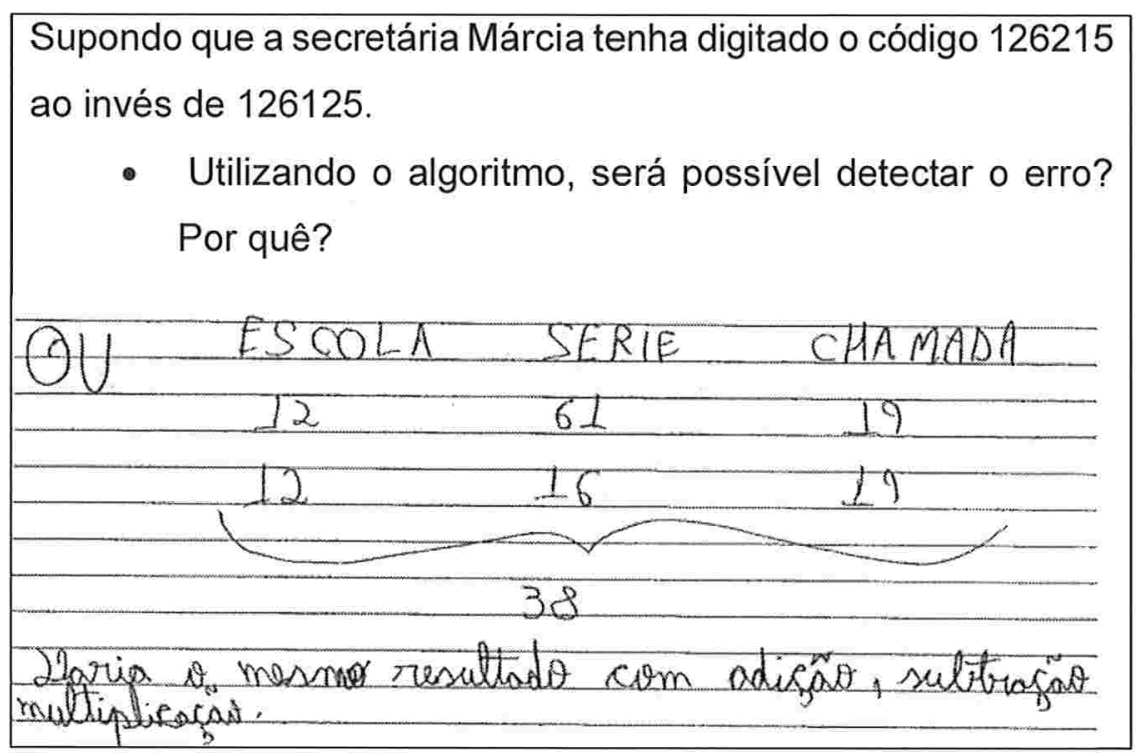

\section{Etapa 2}

Para a realização desta etapa foram utilizados 15 minutos de uma aula. Foi retomado o algoritmo e questionado como:

- Determinar um único dígito verificador.

- Utilizar o dígito verificador para conferir um código.

- A escolha do número base determina a quantidade de dígitos verificadores possíveis. 


\section{Atividade 4}

\section{Etapa 1}

O tempo utilizado: 30 minutos de uma aula.

Organização da turma: Os alunos mantiveram as duplas da atividade anterior.

Pudemos verificar que:

- A maioria dos alunos conseguiu aplicar o algoritmo, utilizado em códigos de barras para a detecção de erros, ao código elaborado e atribuiu o dígito verificador.

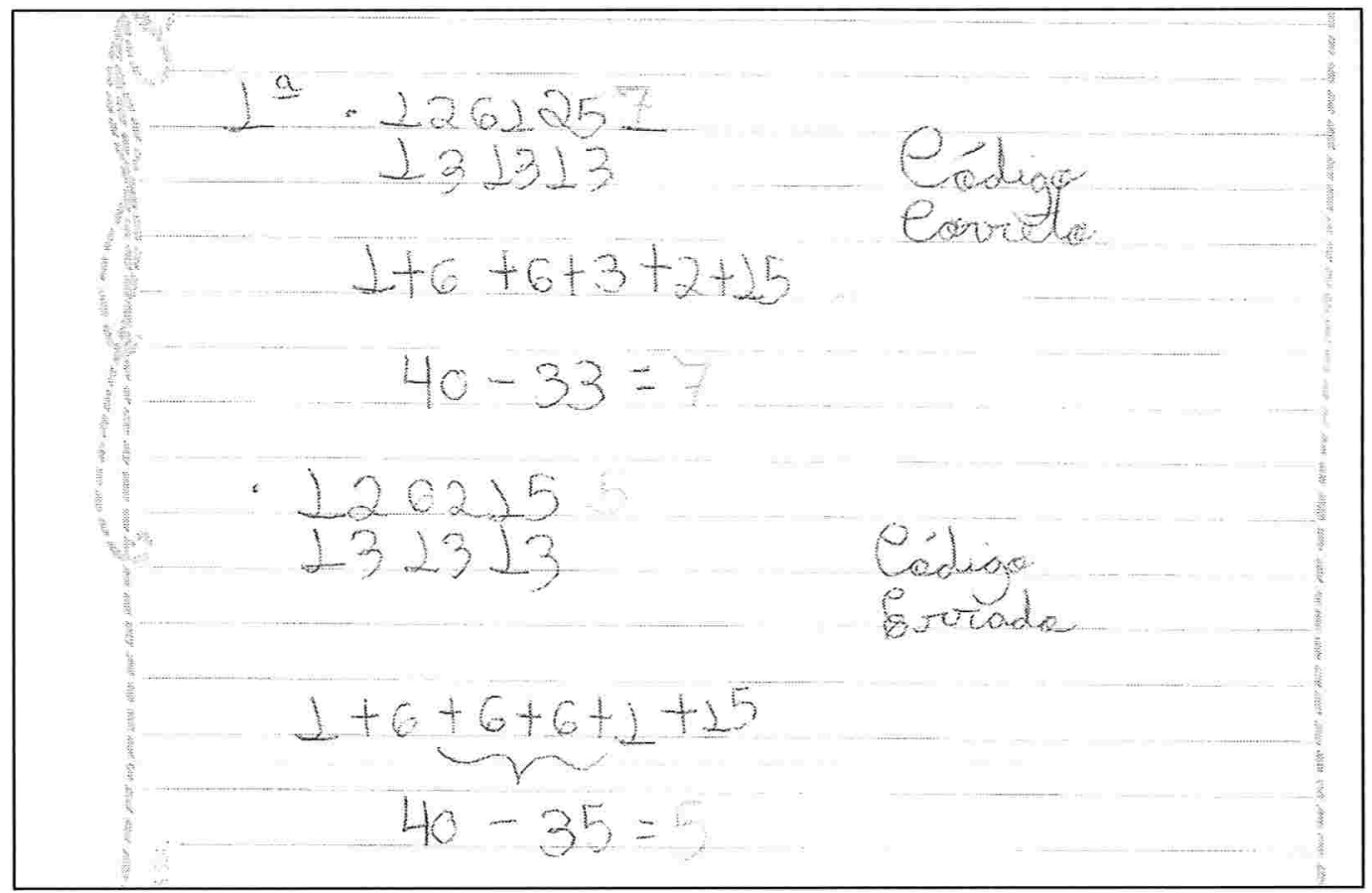

- Os alunos conseguiram utilizar o dígito verificador na detecção de erros.

"Se ela digitasse 126215 ao invés de 126125. O erro poderia ser detectado?" 
105

- 1262,15

131313

$1+6+6+6+1+15=35$ para ser multipla 126125 de 10 palta 5

131313

$1+6+6+3+2+15=33$ para ser mult plo de 10 falta 7

detectado: Sim, a erro podersa ser

"E se o ganhador fosse o aluno 073519 e, sem querer, ela digitasse 037519?"

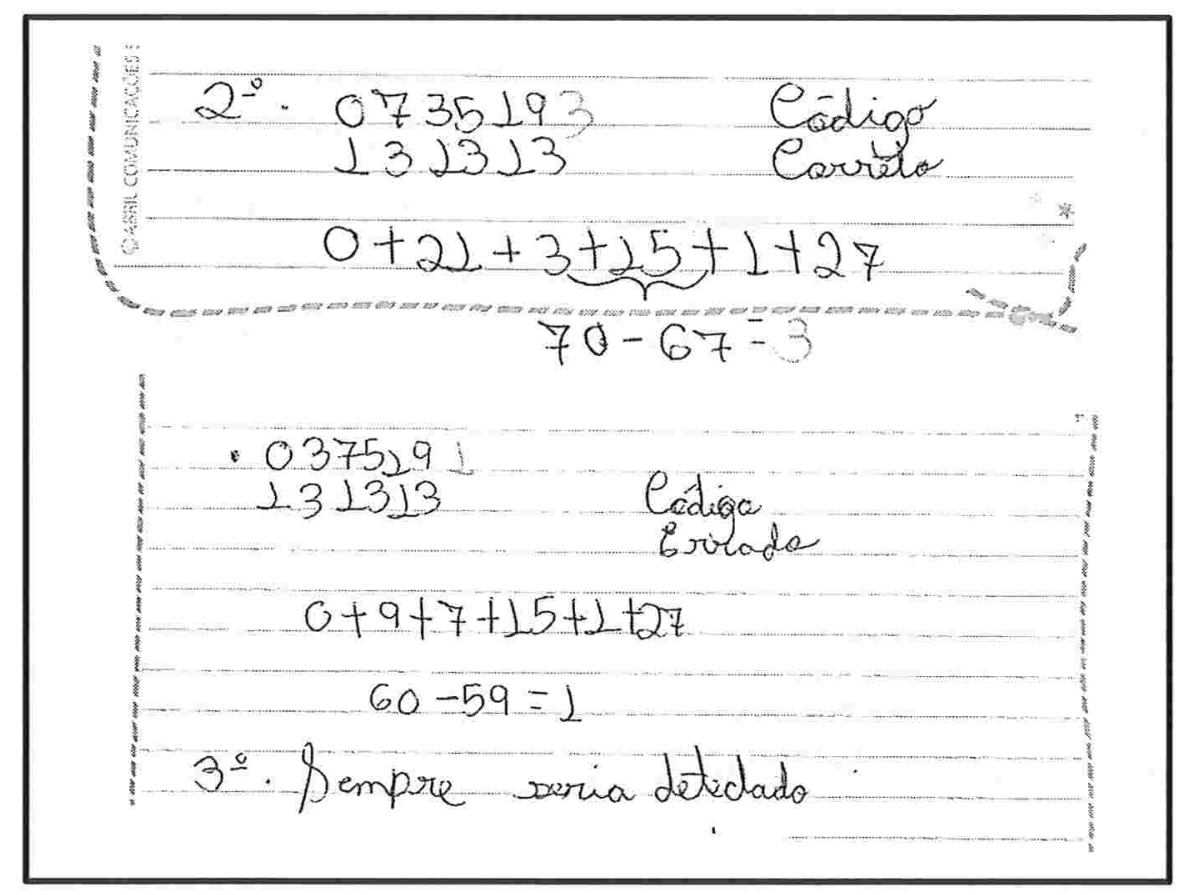

Alguns alunos criaram exemplos de códigos, testaram e analisaram as situações propostas pelo problema. 
"E se o erro fosse trocar a posição (ordem) de dois algarismos seguidos quaisquer do código cuja diferença entre o maior e o menor seja 5. Esse tipo de erro será detectado? "

Para responder a esta pergunta uma das duplas criou e analisou o exemplo abaixo:

097229
131313

$0+27+7+6+2+27=69$

092729

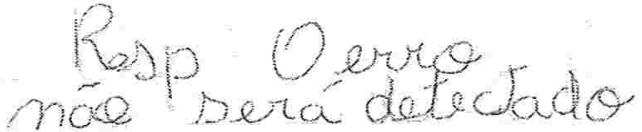

131313

nóe perá detecado

$0+27+2+21+2+27=79$

- Alguns alunos analisaram e testaram o algoritmo aplicando-o apenas aos problemas propostos, para o caso em que, o erro fosse de transposição de dois algarismos consecutivos. Entretanto, alguns alunos motivados e intrigados com sua eficiência, testaram o algoritmo para outro tipo de erro de transposição e apresentaram um exemplo para esse caso, em que o erro não seria detectado.

"Se houver a troca de posição (ordem) de dois algarismos quaisquer do código, sempre será detectado?"

- Uma das duplas pensou em considerar transposição de algoritmos consecutivos e também de algarismos não consecutivos. Eles criaram e analisaram os exemplos abaixo: 


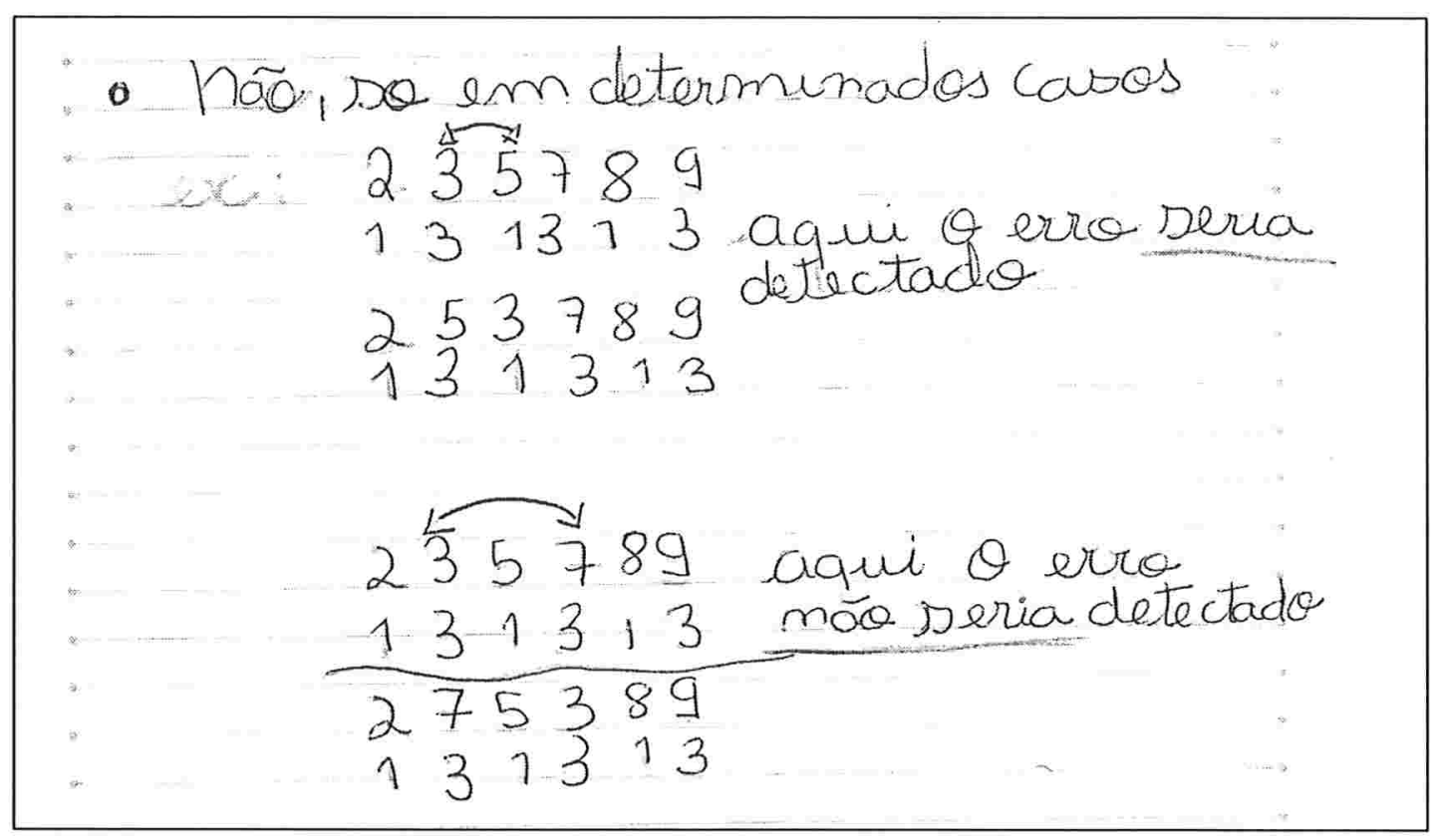

- Alguns alunos conseguiram perceber que erro do tipo "troca de posição (ordem) de dois algarismos consecutivos quaisquer do código cuja diferença entre o maior e o menor seja cinco", podem não ser detectados com a utilização desse algoritmo.

"Supondo que a secretária Márcia tenha digitado o código 121625 ao invés de 126125." 


\section{Etapa 2}

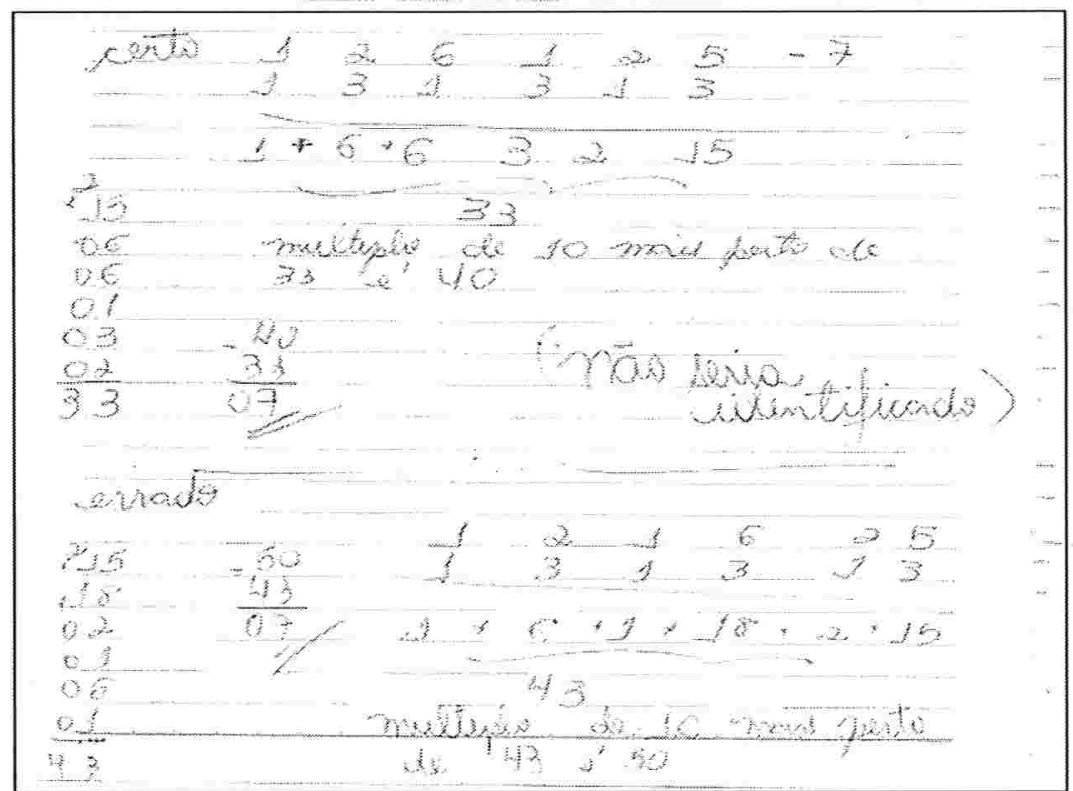

Nesta etapa, foi retomado o algoritmo aplicado e discutido com os alunos, sua eficiência na detecção dos erros de digitação nos problemas propostos pela atividade. Pudemos perceber que:

- Para alguns alunos, o algoritmo não é tão eficiente, pois utiliza apenas os fatores 1 e 3 para multiplicar os algarismos do código. Sendo assim, erros de transposição de algarismos não consecutivos, podem não ser detectados se forem multiplicados pelo mesmo fator.

- Alguns alunos questionaram a utilização do número 10 como número base no algoritmo. Surgiu, então, a discussão sobre qual número deveria ser tomado como base para que uma maior detecção de erros fosse possível.

\section{Atividade 5}

\section{Etapa 1}

O tempo utilizado: 20 minutos de uma aula.

Organização da turma: Alguns alunos preferiram desenvolver a atividade individualmente e outros em duplas. 
As duas turmas desenvolveram a atividade sem a necessidade do auxílio do professor e, durante sua execução, surgiram alguns comentários sobre o número base usado no algoritmo, como:

Aluno B: "eu sabia que com um número primo daria certo! "

Aluno E: "e eu disse que ele tinha que ser maior que 10, para poder ter mais dígitos".

E algumas descobertas, como:

Aluno F: "Ah! Agora entendi porque o dígito do meu RG é a letra X".

Ao analisarmos as resoluções dos alunos, verificamos que:

- O algoritmo foi compreendido e desenvolvido corretamente. Os alunos constataram que ele possibilita a detecção desse tipo de erro: "trocar a posição (ordem) de dois algarismos seguidos quaisquer do código cuja diferença entre o maior e o menor seja 5". E que não é possível quando utilizado o 10 como número base, já verificado na atividade 4 .

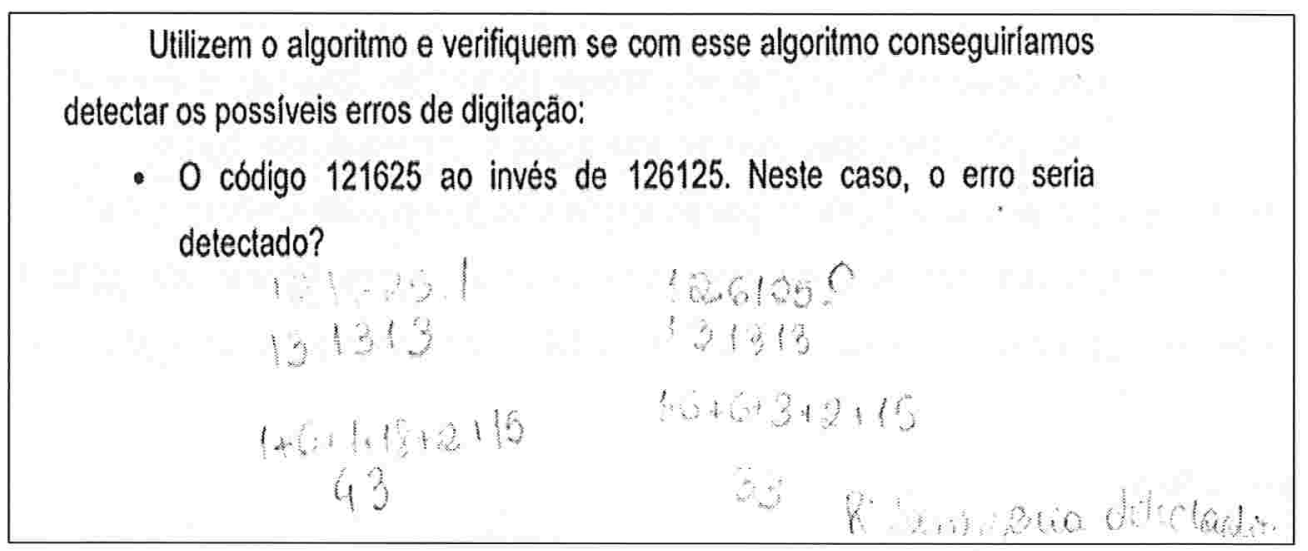

- Analisaram corretamente também, este outro problema proposto:

- O código 072418 ao invés de 027418 . Este erro seria detectado?




- Ao serem questionados sobre a utilização de um número primo no algoritmo, uma das duplas respondeu:

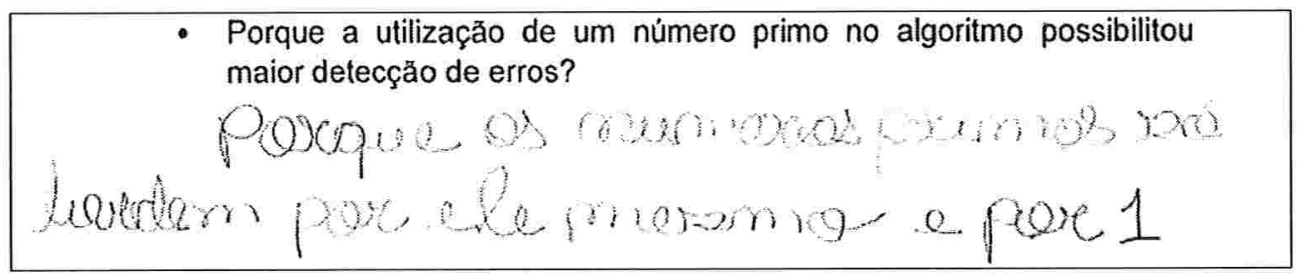

\section{Etapa 2}

O tempo utilizado foi, aproximadamente, 15 minutos de uma aula. Retomou-se o algoritmo sugerido e discutiu-se com os alunos os seguintes itens:

- A substituição no algoritmo do número 10, número base, pelo número primo 11, proporciona maior detecção de erros.

- A utilização de conceitos matemáticos conhecidos, tais como múltiplos e, principalmente, números primos, na elaboração de códigos de identificação. Surgiram então alguns comentários, como:

Aluno F: "Eu achava que número primo fosse usado só para matemática.".

Diante desse comentário aproveitou-se para exemplificar a utilização de números primos em algoritmos, tais como o do RG, ISBN, senhas bancárias e etc.

\section{Atividade 6}

\section{Etapa 1}

Tempo: Foi utilizado uma aula de 50 minutos.

Com a observação e comparação de cada produto com seu respectivo código de barras, os alunos conseguiram identificar quais informações contém cada uma de suas partes.

Apresentamos abaixo as soluções de alguns alunos para as seguintes questões: 
- Comparando os códigos de barras acima você chegou a alguma conclusão sobre que informação contém os três primeiros algarismos?

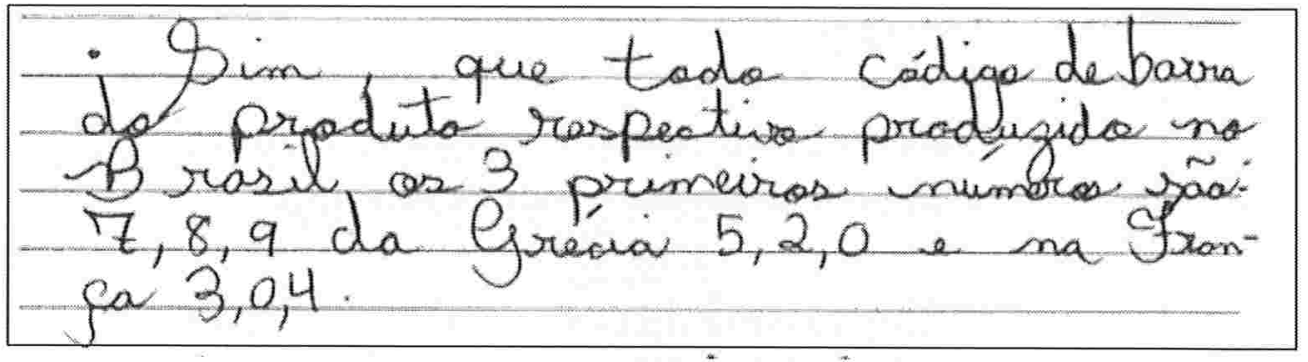

- É possível chegar a alguma conclusão em relação a que informação contém os 4 algarismos da $2^{\mathrm{a}}$ parte do código de barras?

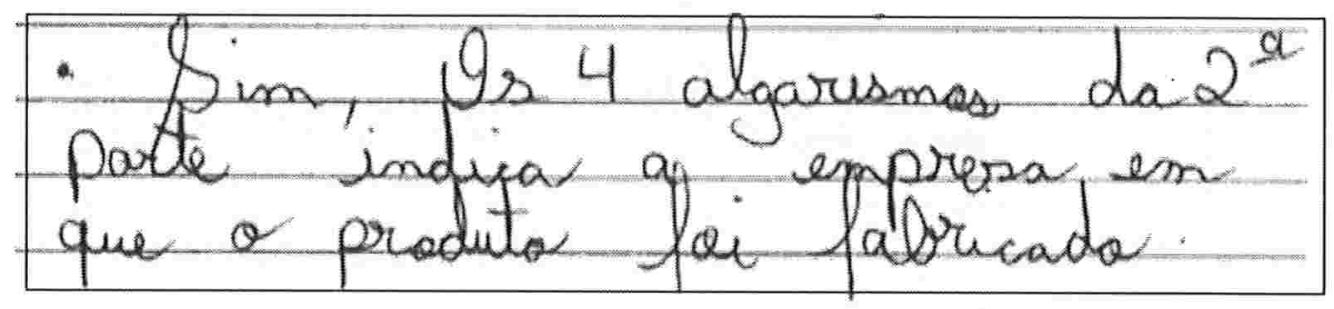

- Em relação aos 5 algarismos da $3^{a}$ parte do código de barras, você chegou a alguma conclusão? Que informação ela contém?

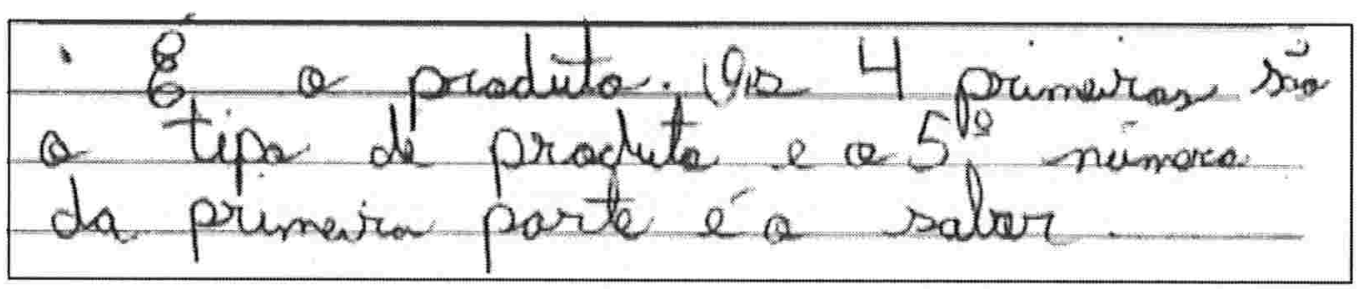

- Os alunos, no geral, aplicaram o algoritmo que foi ensinado na atividade 4, ou seja, multiplicaram todos os algarismos do código pela sequência $1,3,1,3, \ldots$ e somaram os produtos obtidos, tomando o 10 como número base.

Como 90 é o múltiplo de 10 imediatamente superior a soma dos produtos obtida os alunos, em seguida, fizeram a diferença entre 90 e a soma dos produtos e 
obtiveram 5, que é, exatamente, o digito verificador do código de barras do problema.

\section{Como equipe:}

Analisem o codigo de barras do produto abaixo e, baseado nas alividades anteriores, tentem descobrir qual foi o algoritmo utilizado.

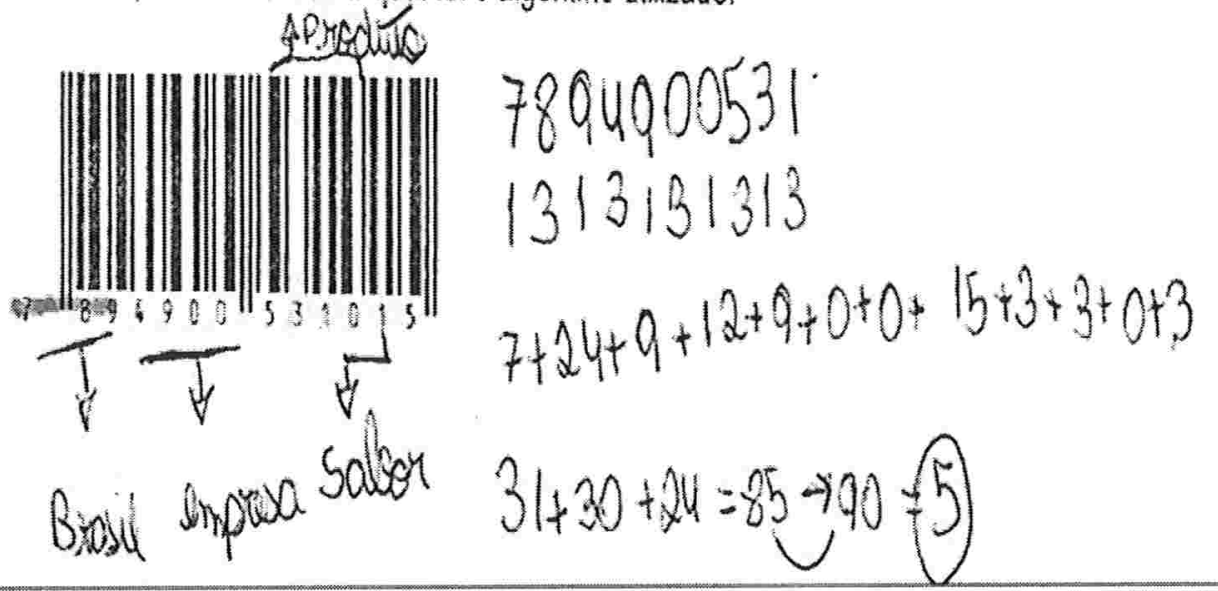

- Para que a soma obtida seja múltiplo de 10 acrescentaram 5, logo o digito verificador é 5 .

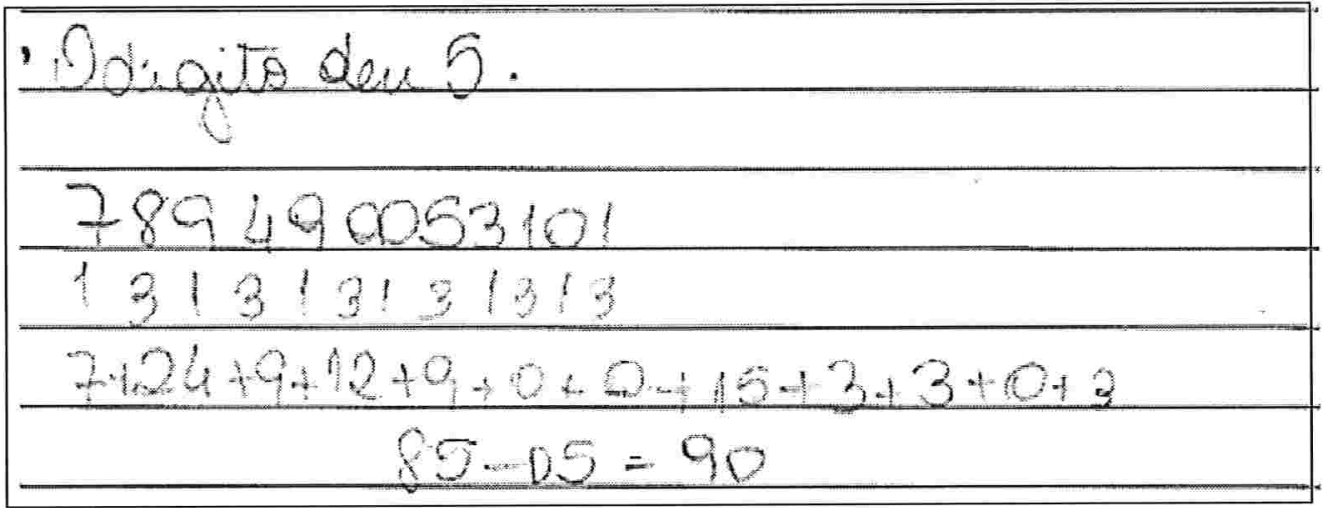

\section{Etapa 2}

Foram utilizados 15 minutos de uma aula para a discussão dessa etapa. Quando questionados sobre quais informações contém os códigos de barras, surgiram os comentários: Aluno C: "Os três primeiros são do país e o código do Brasil é 789". Aluno F: "Depois vem a empresa, o produto e por último o digito verificador.". 
Foi esclarecido que os três primeiros algarismos de um código de barras são do país onde o produto foi registrado pela primeira vez.

Os alunos foram indagados sobre a atribuição do dígito verificador e explicaram corretamente como obtê-lo. Foi questionado também, o número base utilizado e a detecção de erros.

\section{Atividade 7}

\section{Etapa 1}

O tempo utilizado: 20 minutos de uma aula.

Organização da turma: Os alunos realizaram a atividade em duplas.

As duas turmas não tiveram dificuldade na aplicação do algoritmo e na resolução do problema proposto na atividade. Pudemos verificar que: 
- Os alunos conseguiram aplicar o algoritmo e atribuíram corretamente os dígitos verificadores ao CPF do problema proposto

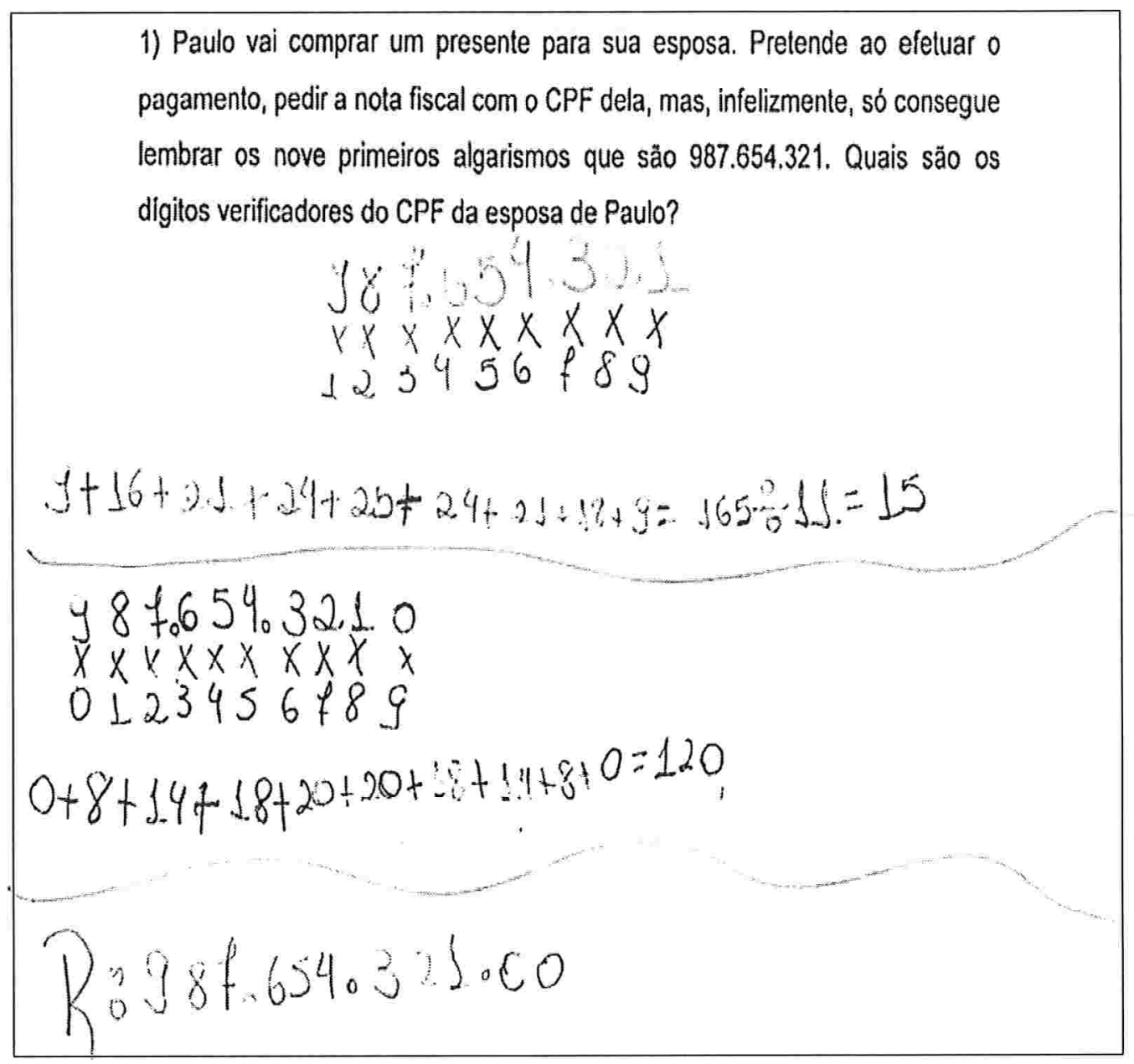




\section{Etapa 2}

Esta etapa foi realizada em 15 minutos de uma aula. Foram discutidos com os alunos alguns procedimentos no algoritmo:

- A utilização de fatores diferentes na multiplicação pelos algarismos do código.

- A atribuição de dois dígitos de verificação no CPF.

- O número base ser um número primo.

- Os conceitos matemáticos envolvidos, tais como múltiplos, números primos, divisibilidade e etc.

\subsection{ALGUMAS OBSERVAÇÕES SOBRE AS ATIVIDADES APLICADAS}

Após o término da sequência didática, foi solicitado aos alunos um breve comentário acerca das atividades. Abaixo estão alguns deles:

Aluno 1:

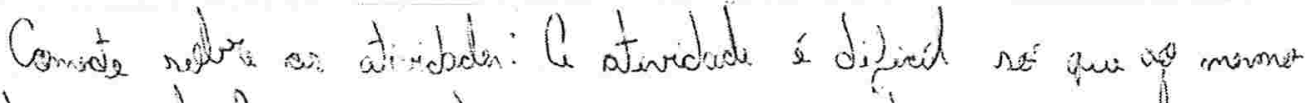

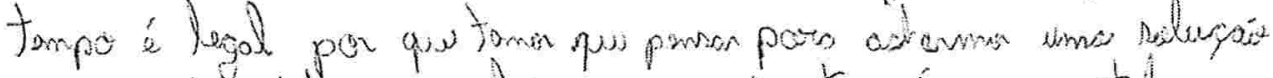

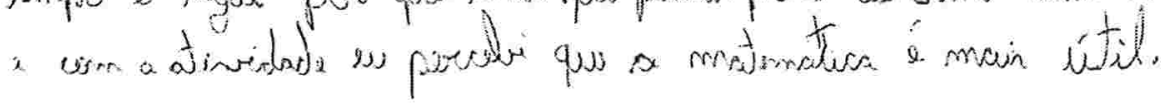

- Este comentário, e outros similares, leva a refletir que o aluno, mesmo reconhecendo a dificuldade do problema, também o considerou "legal", isto é, interessante, pois sentiu-se estimulado ao ver sentido no desafio apresentado, o que o levou a desenvolver uma solução. Tal afirmação vai ao encontro do que é exposto nos Parâmetros Curriculares Nacionais sobre interesses dos alunos e a importância de estimulá-los ao propor uma resolução de situação-problema; 
Aluno 2:

Comute pobre as atuadade:

Eu gastei das tividado e aprande mita givlarem temito.



- Ao longo do processo referente a cada atividade, os alunos puderam elaborar alternativas de possíveis respostas, as quais eles mesmos testaram, analisaram e conjecturaram. Assim, discerniram por meio do seu próprio raciocínio qual das opções era a mais eficaz. Isso nos remete às ideias relacionadas à Resolução de Problemas e a Atividades Investigativas.

Aluno 3:

- Nesse comentário, podemos constatar o sentimento de satisfação produzido no aluno, no momento em que ele percebe sua capacidade de raciocínio para resolver o problema. Nesse caso, vemos a influência de determinadas atividades 
sobre a autoestima do aluno - agora muito mais confiante, como podemos verificar: "até nós conseguimos pensar para resolver os desafios".

Aluno 4:



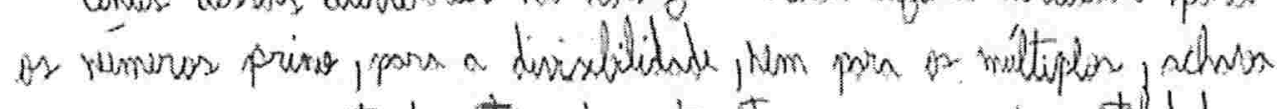



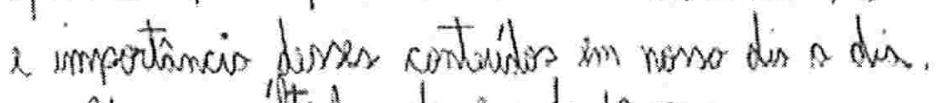

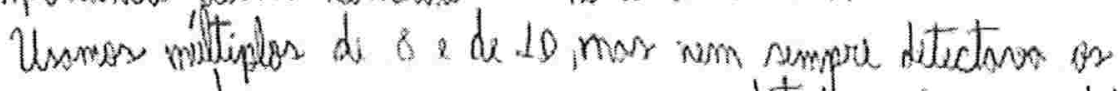

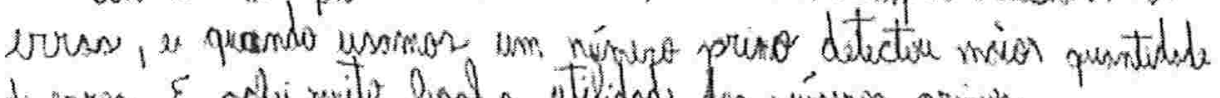

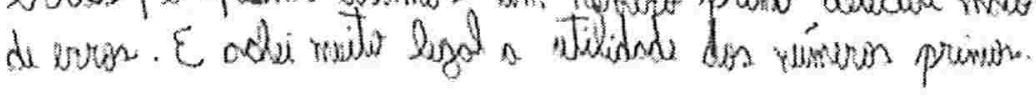

- A descoberta da aplicação de um conteúdo matemático pode gerar um contentamento por parte do aluno, quando ele consegue desenvolver sua habilidade de transferir aquilo que ele aprendeu num contexto para uma situação-problema do cotidiano. 


\section{CONCLUSÃO}

A proposta inicial do trabalho teve o intuito de desenvolver atividades que trouxessem um tema atual relacionado aos conteúdos abordados e, ao mesmo tempo, que despertasse o interesse e a curiosidade dos alunos do Ensino Fundamental II. Por isso, surgiu a ideia de trabalhar com códigos numéricos de identificação, pois utilizam conceitos matemáticos pertinentes a esse nível de ensino - como divisibilidade de números naturais, múltiplos, números primos - e, também, são muito recorrentes no cotidiano. Dentre eles, abordamos alguns exemplos interessantes, como: o CPF, RG, código de barras em mercadorias e o ISBN, os quais utilizam no processo de detecção de erros os conceitos citados acima. Sendo, assim, esse tema apresenta-se como uma oportunidade ao professor de aliar tais motivações.

Para tanto, o próximo passo foi uma análise mais aprofundada das bases Matemáticas presentes nos Códigos de Barras e na detecção de erros. Nela foram abordados os seguintes aspectos: história, estrutura, dígito verificador e, sobretudo, o algoritmo que possibilita detectar eventuais erros de leitura e digitação. Após isso, iniciou-se um estudo metodológico sobre as Atividades Investigativas e a Resolução de Problemas que se tornaram fonte inspiradora no desenvolvimento das atividades a serem propostas.

No entanto, ao longo da elaboração das atividades, surgiram algumas inquietações e, até mesmo, inseguranças de como elas seriam recebidas pelos alunos. A nossa preocupação estava desde o nível de complexidade das tarefas - isto é, se eram condizentes com nível escolar da turma - do tempo que demandaria da aula para a sua execução e, até mesmo, em como manter o interesse e a motivação de cada um deles em querer solucionar cada etapa.

Entretanto, essa preocupação foi sendo diluída na execução das primeiras atividades pelos alunos, que se mostravam cada vez mais entusiasmados durante as discussões entre eles, sobre qual seria a solução mais eficiente, procurando defender seus respectivos pontos de vista. No papel de professora, ao observar tal reação, foi muito satisfatório vê-los "tomando para si" os problemas propostos, analisando cada 
situação, ao criar e testar alternativas de resolução, e, também, contemplar o interesse e a participação de cada um deles.

Ademais, foi muito proveitoso 0 aprofundamento nas metodologias analisadas nesse trabalho, pois contribuíram com o meu desempenho como professora, levando-me a refletir sobre minhas antigas práticas, modificando algumas delas. Se antes considerava imprescindível detalhar ao máximo cada conteúdo, por acreditar que essa maneira seria a mais eficiente para o aprendizado do aluno; hoje, em contrapartida, procuro oferecer condições para que ele consiga construir uma linha de raciocínio coerente com aquilo que pretendo ensinar. Penso, inclusive, que até simples "continhas" podem ser exploradas como um problema, seja de modo individual ou coletivo, desde que conduzam o aluno à reflexão e à prática de pensar matematicamente.

Espero que essa experiência positiva, que pude vivenciar, possa motivar o leitorprofessor a buscar e pesquisar, também, atividades que estimulem a reflexão, a aprendizagem e a articulação de conhecimentos aprendidos anteriormente e proporcionem a socialização dos resultados como novo momento para a argumentação.

A aplicação das atividades e o trabalho desenvolvido pelos alunos permitem constatar que eles recebem com entusiasmo o desafio de analisar novas situações, que esse trabalho os estimula a pesquisar, no nível que é possivel no seu atual estágio de formação, e que eles próprios podem sentir a importância e a utilidade de certos conceitos matemáticos, em particular, neste caso, de ideias fundamentais ligadas à divisibilidade de números inteiros. 


\section{REFERÊNCIAS}

ABRANTES, P., Ponte; J. P.; FONSECA, H.; BRUNHEIRA, L. (1999). Investigações matemáticas na aula e no currículo. Lisboa, pp.57-73.

ALLEVATO, N. S. (2005). Associando o Computador à Resolução De Problemas Fechados: Análise De Uma Experiência. Rio Claro: Tese (Doutorado) - Universidade Estadual Paulista.

ALLEVATO, N.; Onuchic, L. (2009). Ensinando matemática na sala de aula através da resolução de problema. Boletim GEPEM, Rio de Janeiro, Ano XXXIII, n.55, pp.1-19.

BRASIL (país). Ministério da Educação e do Desporto, Secretaria de Educação Fundamental. Parâmetros Curriculares Nacionais: Matemática $-3^{\circ}$ e $4^{\circ}$ ciclos. Brasília: MEC/SEF, 1998.

CUNHA H.; Oliveira, H. P. (1995). Investigações Matemáticas na sala de aula. Lisboa: Actas do ProfMat 95, pp. 161-168.

DANTE,L.R. (2009). Formulação e resolução de problemas de matemática: Teoria e prática. São Paulo: Ática.

ESQUINCA, J. C. (2013). Aritmética: Códigos de barras e outras Aplicações de Congruências. Campo Grande: Centro de Ciências de Exatas e Tecnologia, UFMS.

FONSECA,H.; BRUNHEIRA, L.; PONTE, J.P.(1999). As atividades de investigação, o professor e a aula de matemática. Actas do ProfMat 99. Lisboa: APM.

LAMONATO, M.; PASSOS, C. L. (2011). Discutindo resolução de problemas e exploração-investigação. Zetetiké, pp. 50-74.

LIMA, E. L. Conceituação, manipulação e aplicações - os três componentes do ensino da Matemática. Revista do Professor de Matemática, São Paulo, n.41, p.1-6, 1999.

MENDONÇA, M.C.D. (1999) Resolução de Problemas Pede (Re)Formulação. In: ABRANTES, P. et al (Org.). Investigações Matemáticas na Aula e no Currículo. Lisboa: APM, p.15-33.

ONUCHIC, L. R. (1999) Ensino-aprendizagem de Matemática através da resolução de problemas. In: BICUDO, M. A. V.(Org.). Pesquisa em Educação Matemática. São Paulo: Editora UNESP, cap.12, p.199-220.

ONUCHIC, L.; ALLEVATO, N. (2004). Novas reflexões sobre o ensino-aprendizagem de Matemática através da resolução e problemas. Em M. A. BICUDO, M. C. BORBA, Educação Matemática - pesquisa em movimento. (pp. 213-231). São Paulo: Cortez.

POLCINO MILIES, C. (s.d.). Codificação e Criptografia RSA. São Paulo: notas de aula. 
POLCINO MILIES, C. (2008). A Matemática dos Códigos de Barras. Revista do Professor de Matemática - 65, pp. 46-53.

POLCINO MILIES C.; COELHO, S. (2001). Números: Uma Introdução à Matemática, 3. ed. São Paulo: EDUSP.

POLYA, G. (1985). Ensino por meio de problemas. Revista do Professor de Matemática, n. 7. Rio de Janeiro: SBM, 1985. p. 11-16.

PONTE, J. P.; BROCARDO, J.; OLIVEIRA, H. (2005). Investigações Matemáticas na Sala de Aula. Belo Horizonte: Autêntica.

SANTOS, M. C. (2002). Algumas concepções sobre o ensino-aprendizagem de matemática. Educação Matemática em Revista, São Paulo. v.9, n.12, p.11-15,

SANTOS, J. (2013). A Arte de Cifrar, Criptografar, Esconder e Salvaguardar como Fontes Motivadoras para Atividades de Matemática Básica. Salvador: Universidade Federal da Bahia.

SILVA, V. A. (2010). Propostas de Utilização de Códigos de Barras como Recurso Didático para o Ensino da Matemática - Matemática e suas Tecnologias. Currículo do Estado de São Paulo. São Paulo: SEE.

TAMAROZZI, A. C. (2001). Codificando e decifrando mensagens. São Paulo: Revista do Professor de Matemática 45, Sociedade Brasileira de Matemática.

TERADA, R. (2001). Criptografia e a Importância de suas aplicações. Revista do Professor de Matemática - 45, pp. 1-6.

VAN DE WALLE, J. A. (2009). Matemática do Ensino Fundamental: Formação de Professores e Aplicação em Sala de Aula. $6^{a}$ ed. Porto Alegre: Artmed. 